PNL-10728

UC-602

\title{
RADIONUCLIDE CONCENTRATIONS IN TERRESTRIAL VEGETATION AND SOIL ON AND AROUND THE HANFORD SITE, 1983 THROUGH 1993
}

\section{DISCLAIMER}

T. M. Poston

E. J. Antonio

A. T. Cooper

August 1995
This report was prepared as an account of work sponsored by an agency of the United States Government. Neither the United States Government nor any agency thereof, nor any of their employees, makes any warranty, express or implied, or assumes any legal liability or responsibility for the accuracy, completeness, or usefulness of any information, apparatus, product, or process disclosed, or represents that its use would not infringe privately owned rights. Reference herein to any specific commercial product, process, or service by trade name, trademark, manufacturer, or otherwise does not necessarily constitute or imply its endorsement, recommendation, or favoring by the United States Government or any agency thereof. The views and opinions of authors expressed herein do not necessarily state or reflect those of the United States Government or any agency thereof.

Prepared for

the U.S. Department of Energy

under Contract DE-AC06-76RLO 1830

Pacific Northwest Laboratory

Richland, Washington 99352

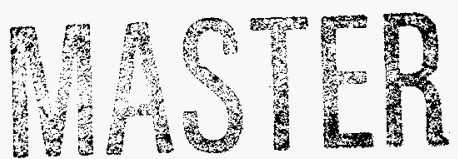




\section{DISCLAIMER}

Portions of this document may be illegible in electronic image products. Images are produced from the best available original document. 


\section{Summary}

This report reviews concentrations of ${ }^{60} \mathrm{Co},{ }^{90} \mathrm{Sr},{ }^{137} \mathrm{Cs}$, $\mathrm{U}$ isotopes, ${ }^{238} \mathrm{Pu},{ }^{239,240} \mathrm{Pu}$, and ${ }^{241} \mathrm{Am}$ in soil and vegetation samples collected from 1983 through 1993 during routine surveillance of the Hanford Site. Sampling locations were grouped in study areas associated with operational areas on the Site. While radionuclide concentrations were very low and representative of background concentrations from historic fallout, some study areas on the Site contained slightly elevated concentrations compared to other study areas onsite and offsite. The 100 Areas had concentrations of ${ }^{60} \mathrm{Co}$ comparable to the minimum detectable concentration of $0.02 \mathrm{pCi} / \mathrm{g}$ in soil. Concentrations of ${ }^{90} \mathrm{Sr},{ }^{137} \mathrm{Cs},{ }^{238} \mathrm{Pu},{ }^{239,240} \mathrm{Pu}$, and ${ }^{241} \mathrm{Am}$ in 200 Area soils were slightly elevated. The 300 Area had a slight elevation of $U$ in soil. These observations were expected because many of the sampling locations were selected to monitor specific facilities or operations at the operational areas. Generally, concentrations of the radionuclides studied were greater and more readily measured in soil samples compared to vegetation samples. The general pattern of concentrations of radionuclide concentrations in vegetation by area mirrored that observed in soil.

Declines in ${ }^{90} \mathrm{Sr}$ in soil appear to be attributed to radioactive decay and possibly downward migration out of the sampling horizon. The other radionuclides addressed in this report strongly sorb to soil and are readily retained in surface soil. Because of their long half-lives compared to the length of the study period, there was no significant indication that concentrations of $U$ isotopes and $\mathrm{Pu}$ isotopes were decreasing over time. 



\section{Acknowledgments}

The authors express their appreciation to M. R. Sackschewsky, K. R. Price, R. L. Dirkes, and R. W. Hanf, Jr., for critical reviews of this report. Soil and vegetation sample collection was performed by numerous Radiation Control Technicians under the supervision of M. D. Quarders and E. W. Lusty. M. K. DeSmet and D. A. Carrothers provided editorial and publication assistance. 



\section{Contents}

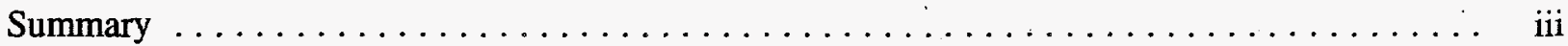

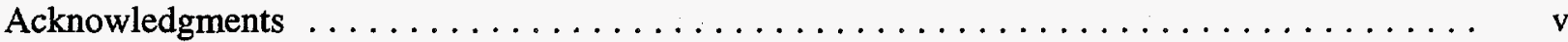

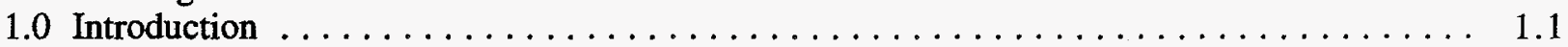

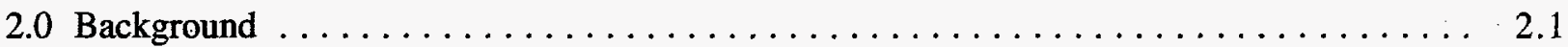

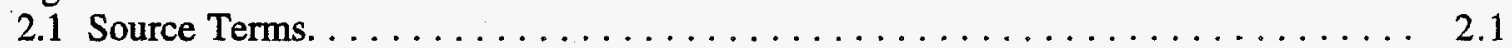

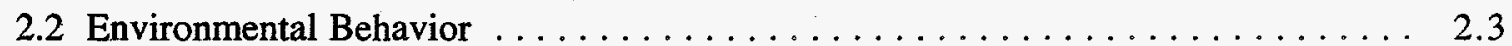

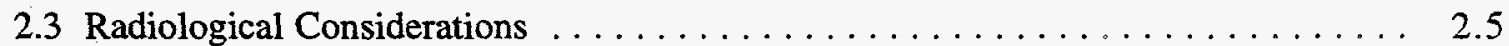

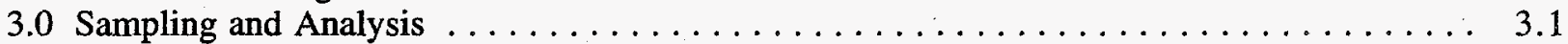

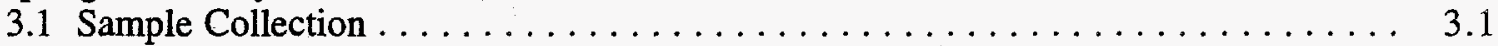

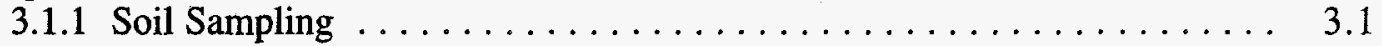

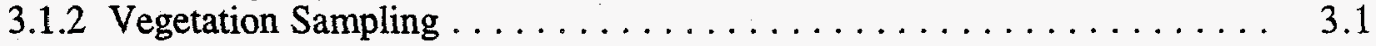

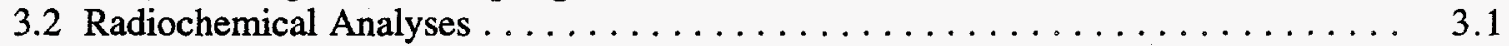

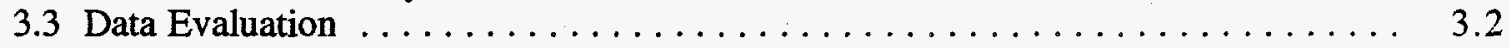

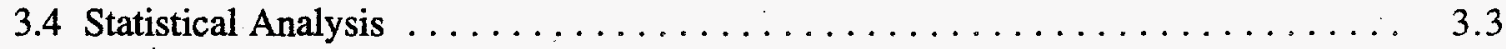

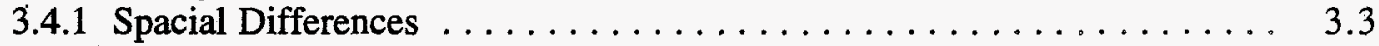

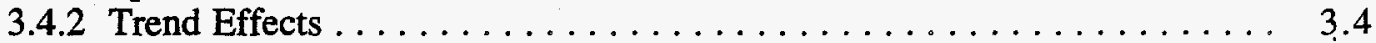

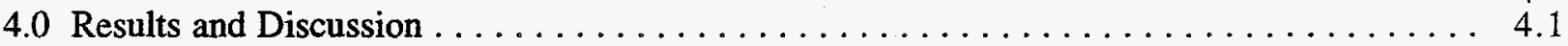

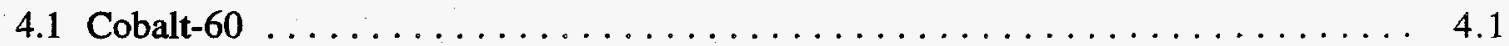

4.1 .1 Soil . . . . . . . . . . . . . . . . . . . . . . 4.1

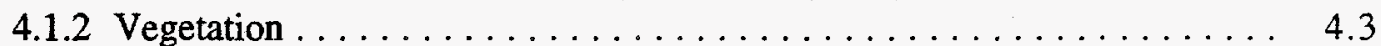

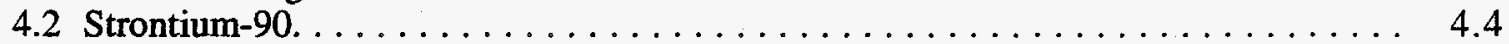

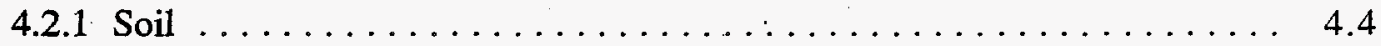

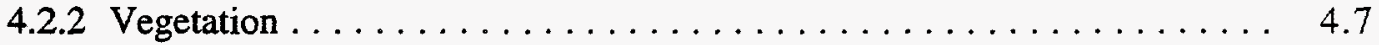

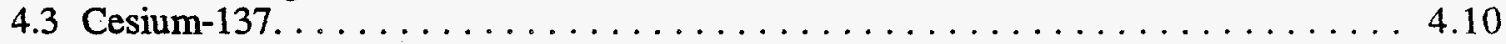

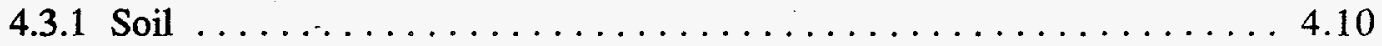

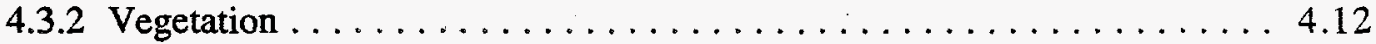

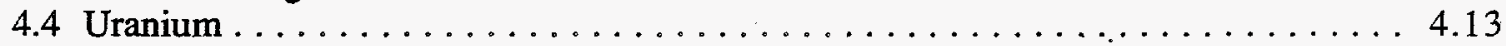

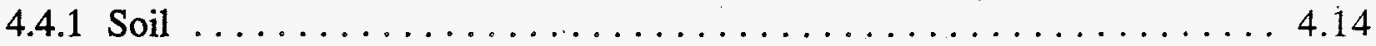

4.4 .2 Vegetation ............................ 4.19

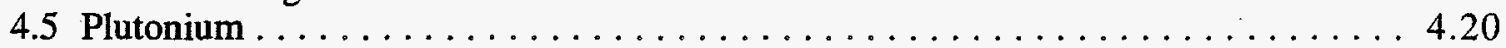

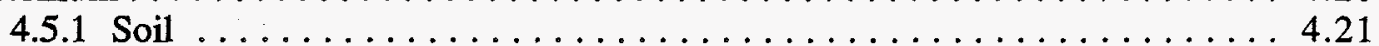

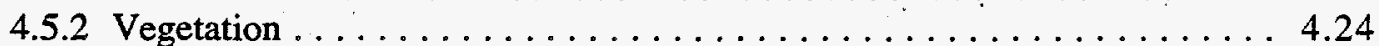

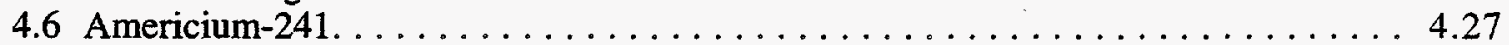

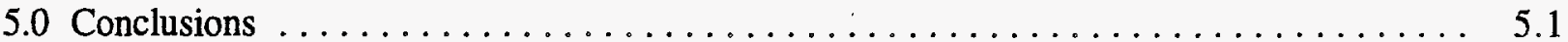

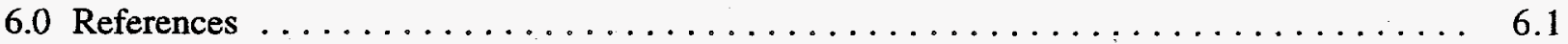

Appendix A Atmospheric Source Terms . . . . . . . . . . . . . . . . . . A.1

Appendix B Soil and Vegetation Sampling Frequency $\ldots \ldots \ldots \ldots \ldots \ldots \ldots \ldots \ldots \ldots \ldots$ B.1

Appendix C Statistical Analysis Tables and Box Plots $\ldots \ldots \ldots \ldots \ldots \ldots \ldots \ldots \ldots$ C.1 



\section{Figures}

2.1 General Operating Areas and Soil and Vegetation Sampling Locations on and Around the Hanford Site $\ldots \ldots \ldots \ldots \ldots \ldots \ldots \ldots \ldots \ldots \ldots \ldots \ldots \ldots \ldots \ldots .2$

4.1 Annual Median Concentrations of ${ }^{60} \mathrm{Co}$ in Soil by Study Area $\ldots \ldots \ldots \ldots .2$

4.2 Annual Median Concentrations of ${ }^{60} \mathrm{Co}$ in Vegetation by Study Area . . . . . . 4.4

$4.3 \quad$ Annual Median Concentrations of ${ }^{90} \mathrm{Sr}$ in Soil by Study Area . . . . . . . . 4.5

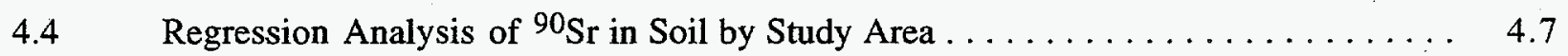

4.5 Annual Median Concentrations of ${ }^{90} \mathrm{Sr}$ in Vegetation by Study Area . . . . . . . 4.9

4.6 Regression Analysis of ${ }^{90} \mathrm{Sr}$ in Vegetation by Study Area $\ldots \ldots \ldots \ldots . \ldots$

$4.7 \quad$ Annual Median Concentrations of ${ }^{137} \mathrm{Cs}$ in Soil by Study Area . . . . . . . 4.11

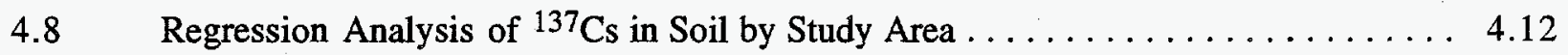

4.9 Annual Median Concentrations of ${ }^{137} \mathrm{Cs}$ in Vegetation by Study Area . . . . . . 4.14

4.10 Annual Median Concentrations of $U$ in Soil (Fluorometric Analysis)

4.11 Annual Median Concentrations of ${ }^{238} \mathrm{U}$ in Soil (LEPS) by Study Area . . . . . . 4.15

4.12 Annual Median Concentrations of $238 \mathrm{U}$ in Soil (Alpha Spectroscopy)

Annual Median Concentrations of Total $U$ in Vegetation (Fluorometric
Analysis) by Study Area $\ldots \ldots \ldots \ldots \ldots \ldots \ldots \ldots \ldots \ldots \ldots \ldots \ldots \ldots \ldots \ldots \ldots \ldots \ldots$

4.14 Annual Median Concentrations of ${ }^{238} \mathrm{Pu}$ in Soil by Study Area . . . . . . . . . 4.21

4.15 Annual Median Concentrations of ${ }^{239,240} \mathrm{Pu}$ in Soil by Study Area . . . . . . . 4.22

4.16 Regression Analysis of $239,240 \mathrm{Pu}$ in Soil by Study Area . . . . . . . . . . . 4.24

4.17 Annual Median Concentrations of ${ }^{239,240} \mathrm{Pu}$ in Vegetation by Study Area $\ldots . .4 .25$

4.18 Regression Analysis of ${ }^{239,240} \mathrm{Pu}$ in Vegetation by Study Area . . . . . . . . 4.27

4.19 Annual Median Concentrations of ${ }^{241} \mathrm{Am}$ in Vegetation by Study Area ...... 4.28 


\section{Tables}

2.1. Dissociation Constants $\left(\mathrm{K}_{\mathrm{d}}\right)$ for Radionuclides in Freshwater and

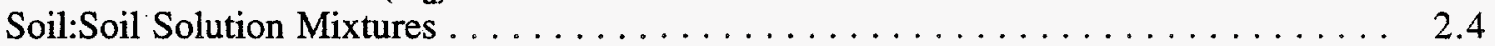

2.2. Concentration Ratios $(\mathrm{CR})$ for Radionuclides in Plants $\ldots \ldots \ldots \ldots \ldots \ldots \ldots$

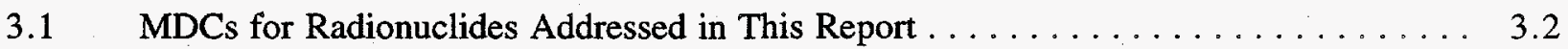

3.2 Summary of Statistical Analyses Performed on Soil and Vegetation Data . . . . . . 3.4

4.1 Descriptive Statistics for ${ }^{60} \mathrm{Co}$ in Soil $\ldots \ldots \ldots \ldots \ldots \ldots \ldots \ldots \ldots \ldots \ldots \ldots \ldots \ldots$

4.2 Descriptive Statistics for ${ }^{60} \mathrm{Co}$ in Vegetation $\ldots \ldots \ldots \ldots \ldots \ldots \ldots$

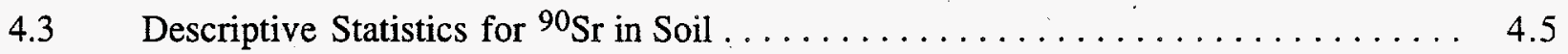

4.4 Summary of Regression Analysis and ANOVA of Log Median (LM)

${ }^{90} \mathrm{Sr}$ in Soil . . . . . . . . . . . . . . . . . . . . . . . . . 4.6

$4.5 \quad$ Percentage Decrease of ${ }^{90} \mathrm{Sr}$ in Soil Samples $\ldots \ldots \ldots \ldots \ldots \ldots \ldots \ldots \ldots \ldots$

4.6 Descriptive Statistics for ${ }^{90} \mathrm{Sr}$ in Vegetation $\ldots \ldots \ldots \ldots \ldots \ldots \ldots \ldots$

4.7 Summary of Regression Analysis and ANOVA of Log Median (LM)

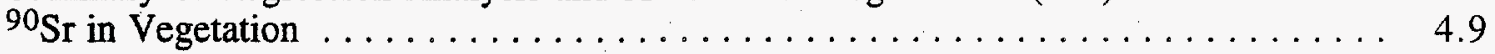

$4.8 \quad$ Descriptive Statistics for ${ }^{137} \mathrm{Cs}$ in Soil $\ldots \ldots \ldots \ldots \ldots \ldots \ldots \ldots \ldots \ldots \ldots$

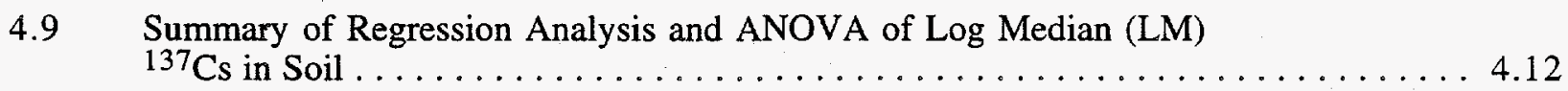

4.10 Descriptive Statistics for ${ }^{137} \mathrm{Cs}$ in Vegetation $\ldots \ldots \ldots \ldots \ldots \ldots \ldots \ldots$

4.11 Descriptive Statistics for U (Fluorometric Analysis) in Soil . . . . . . . . . 4.16

4.12 Descriptive Statistics for ${ }^{238} \mathrm{U}$ (Alpha Spectroscopy) in Soil . . . . . . . . . . 4.17

4.13 Descriptive Statistics for ${ }^{238} \mathrm{U}$ (LEPS Analysis) in Soil . . . . . . . . . . 4.17

4.14 Atom Percentage of U Isotpes in Sagemoor Soils, 1992 Samples . . . . . . . . . 4.18

4.15 Descriptive Statistics for U (Fluorometric Analysis) in Vegetation . . . . . . . . 4.20

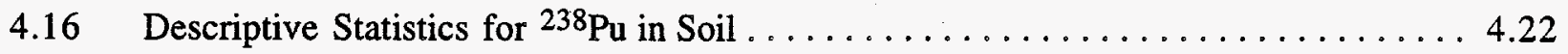

4.17 Descriptive Statistics for $239,240 \mathrm{Pu}$ in Soil $\ldots \ldots \ldots \ldots \ldots \ldots \ldots \ldots \ldots$

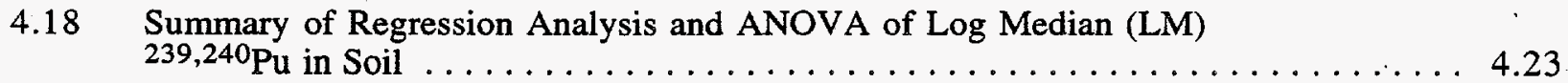


4.19 Descriptive Statistics for ${ }^{239,240} \mathrm{Pu}$ in Vegetation $\ldots \ldots \ldots \ldots \ldots \ldots \ldots$

4.20 ANOVA of Log-Transformed ${ }^{239,240} \mathrm{Pu}$ Concentrations in Vegetation by Study Area and Laboratory . . . . . . . . . . . . . . . . . 4.26

4.21 Summary of Regression Analysis and ANOVA of Log Median (LM) $239,240 \mathrm{Pu}$ in Vegetation 


\subsection{Introduction}

The U.S. Department of Energy's (DOE's) Hanford Site was established in 1943 in southeastern Washington State for nuclear materials production. Although the Site is quite large $\left(1450 \mathrm{~km}^{2}\left[560 \mathrm{mi}^{2}\right]\right.$ ), only about $6 \%$ of the Site has been developed for industrial purposes (Dirkes et al. 1994). Environmental monitoring at the Hanford Site documents levels of radionuclides in many types of environmental media. Historically, environmental monitoring has included agricultural products, soil, vegetation, air, surface and ground water, wildlife, fish, and other aquatic organisms with the objective of identifying and quantifying contaminant contributions from the Hanford Site. Monitoring information has been published in monthly, quarterly, and, since 1957, annual reports to summarize the environmental status of the Hanford Site. The most recent annual report was published in June 1994 for the 1993 calendar year (Dirkes et al. 1994).

The recent shift from nuclear materials production to an emphasis on environmental restoration at the Hanford Site has focused additional attention on potential environmental contamination around the Site. Monitoring data are used primarily to estimate the environmental dose to the public residing around the Hanford Site. Historical monitoring data have been used extensively to calculate dose estimates for the Hanford Environmental Dose Reconstruction Project (HEDR) (Denham et al. 1993; Heeb and Bates 1994). Surveillance data have been used to assess concentrations and trends of radioactive contamination in many environmental media (Eberhardt et al. 1989; Patton and Cooper 1993; Antonio 1994; Dirkes 1994; Poston 1994; Poston and Cooper 1994).

The data used in this study were collected during routine monitoring of the Hanford Site. The objectives of soil and vegetation monitoring efforts were to:

- monitor the buildup and inventory of long-lived radionuclides at onsite and offsite locations from the deposition of airborne releases, from stacks and vents, or resuspended dust from clean-up activities

- provide assurance to the public that the degree of contamination from Hanford Site operations is known and quantified

- provide baseline soil and vegetation data to quantify any incremental changes resulting from unexpected releases of radioactivity and long-term buildup of radionuclides

- conduct surveillance to meet Fast Flux Test Facility (FFTF) technical specifications (HEDL 1981).

The objective of this report is to evaluate the concentrations of radionuclides in soil and vegetation samples collected onsite and offsite as documented by the Sitewide surveillance program. Additional programs have been conducted for soil and vegetation monitoring by the Site operating contractors in association with the operation of specific facilities. Generally, these studies are conducted near specific Site facilities and within defined operational areas. This report focuses on onsite soil and vegetation samples collected outside of facility boundaries and fence lines and on samples collected offsite at locations on the Site perimeter and at more distant locations. The data were evaluated for differences among study areas and for demonstrable trends over the study period. 
The radiochemical analyses used to monitor radionuclides in soil and vegetation are extremely sensitive, and past monitoring has documented the accumulation of low-levels of radionuclides at several areas. Atmospheric fallout from past nuclear weapons testing programs may also contribute to levels of radionuclides analyzed in environmental media collected for Site surveillance. The report specifically addresses ${ }^{60} \mathrm{Co},{ }^{90} \mathrm{Sr},{ }^{137} \mathrm{Cs}$, $\mathrm{U}$ isotopes, ${ }^{238} \mathrm{Pu},{ }^{239}, 240 \mathrm{Pu}$, and ${ }^{241} \mathrm{Am}$ in surface soil and vegetation samples. Gamma spectroscopy provides information on a number of other radionuclides; however, these are consistently below the level of detection and are not discussed in this report.

Many of the surveillance sampling locations were selected to monitor specific facilities. It is assumed that slightly elevated concentrations of specific radionuclides may be found in those areas. The surveillance program was not designed to characterize these areas; that would entail a random assignment of sampling locations on a much broader scale. The analyses and evaluations conducted in this report provide a simple comparison of the defined study areas and trends over the 1983 through 1993 time period. 


\subsection{Background}

Soil and vegetation sampling has been performed on the Hanford Site since the first production reactor went on-line in 1944 (Denham et al. 1993). This section briefly discusses information regarding source terms for radioactivity in soil and vegetation and some of the radiological characteristics of the radionuclides found in soil and vegetation samples. For purposes of comparison, estimates of early releases for some radionuclides have been provided where these data were readily available.

\subsection{Source Terms}

Environmental surveillance at the Hanford Site has included soil and vegetation sampling at onsite and offsite locations. There are two primary sources of environmental radioactivity at Hanford. The most obvious source has been Hanford Site operations. Airborne releases for the various operating areas onsite have been reported in the annual Hanford Site monitoring reports(a) and have been graphically summarized for the study period (see Appendix A). Additionally, atmospheric releases of ${ }^{90} \mathrm{Sr}$ and ${ }^{239} \mathrm{Pu}$ have been summarized as part of HEDR for the period 1944 through 1972 (Heeb 1994). The value of the dose reconstruction document is that it provides summary information for stack releases to serve as a historical reference for comparing releases to the atmosphere during the study period addressed in this report. Heeb (1994) did not summarize ${ }^{60} \mathrm{Co}$, ${ }^{137} \mathrm{Cs}$, $\mathrm{U}$ isotopes, and ${ }^{241} \mathrm{Am}$ releases because these radionuclides did not significantly contribute to human dose by the inhalation pathway. Generally, the total amount of $\mathrm{Ci}$ releases provided by Heeb (1994) for ${ }^{90} \mathrm{Sr}$ and ${ }^{239} \mathrm{Pu}$ greatly exceed the estimated releases for the study period considered in this report.

Reported releases for the study period were documented in Sitewide annual surveillance reports and were grouped into four operating areas (Figure 2.1): 100 Areas (reactor sites along the Columbia River), 200 Areas (fuel reprocessing and waste management), 300 Area (research and fuel fabrication), and the 400 Area (site of the FFTF). Soil and vegetation monitoring locations located around the 400 Area were grouped as 600 Area samples in this report. The 600 Area includes all undeveloped areas on the Hanford Site. At no time did reported releases of ${ }^{60} \mathrm{Co}$ or ${ }^{137} \mathrm{Cs}$ exceed $1.0 \mathrm{Ci}$ for a given calendar year from 1983 through 1993 (see Appendix A). The highest releases of ${ }^{60} \mathrm{Co}$ occurred in the 100 Areas, while the highest releases of ${ }^{90} \mathrm{Sr}$ and ${ }^{137} \mathrm{Cs}$ occurred in the 200 Areas. Releases of ${ }^{90} \mathrm{Sr}$ never exceeded $0.05 \mathrm{Ci} /$ year during the study period. The total Ci inventory of atmospheric releases of ${ }^{90} \mathrm{Sr}$ from 1944 through 1972 was $64.32 \mathrm{Ci}$ (Heeb 1994).

The greatest annual airborne releases of $\mathrm{Pu}$ isotopes also occurred in the 200 Areas and did not exceed $0.05 \mathrm{Ci} /$ year for any given year from 1983 through 1993 . The total estimated release of ${ }^{239} \mathrm{Pu}$ from 1944 to 1972 in the 200 Areas was $1.78 \mathrm{Ci}$. Releases for U isotopes have been reported by isotope and as total $\mathrm{U}$, an expression based on fluorometric analysis. Reported releases during the study period were similar between the 300 Area and the 200 Areas and did not exceed $0.1 \mathrm{mCi} /$ year in any given year.

(a) A listing of Site monitoring reports is found at the end of Section 6.0 


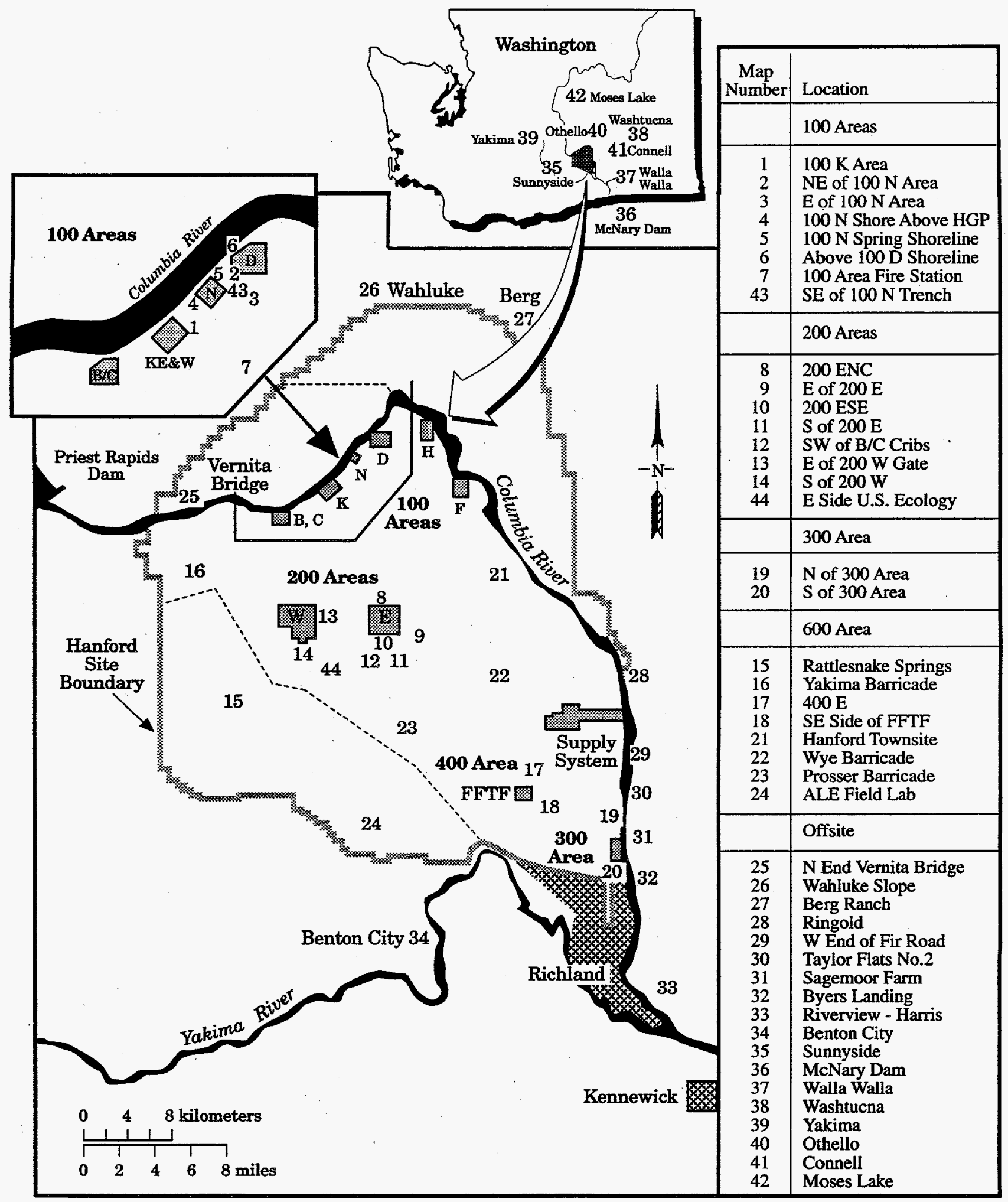

Figure 2.1. General Operating Areas and Soil and Vegetation Sampling Locations on and Around the Hanford Site 
The other significant source term for radionuclides found in soil and vegetation was fallout from atmospheric weapons testing that was conducted during the 1950s through the 1980s (Perkins and Thomas 1980). In 1986, the Chernobyl accident also resulted in measurable amounts of radioactivity in environmental media sampled at Hanford (Price 1987; Woodruff 1987); however, any long-term contribution from Chernobyl to existing concentrations of radionuclides addressed in this report are considered to be insignificant at and around the Hanford Site. Offsite concentrations of fallout radionuclides provide a good indication of background concentrations of the radionuclides addressed in this report. Background concentrations of radionuclides attributed to fallout are directly related to the amount of precipitation an area receives. Areas with higher precipitation will have correspondingly higher levels of background radionuclides. This relationship is evident in fish, deer, and water samples that have been collected during Hanford Site surveillance sampling (MacLellan et al. 1993; Dirkes 1994; Poston 1994; Poston and Cooper 1994).

Secondary source terms associated with Hanford Site activities would include resuspension and dispersion of fugitive dust. Estimates of offsite impacts to individuals indicate that fugitive dust may contribute to exposure to low-level radiation (Fox-Williams 1993); however, the uncertainty associated with these estimates is very high and the potential doses are very low.

\subsection{Environmental Behavior}

The radionuclides addressed in this report were selected because they were found in soil and vegetation samples during the study period. All of these radionuclides sorbed to soil particles and have different degrees of mobility in the environment. A relative indication of the soil binding potential of these radionuclides is provided by the $\mathrm{K}_{\mathrm{d}}$ value, a dimensionless dissociation constant that represents the soil binding potential of a radionuclide (Booth 1976). $K_{d}$ values have been used in aquatic systems to define partitioning of radionuclides between water and sediment. In both systems, the larger the $K_{d}$ value, the greater the sorption to soil or sediment. The environmental chemistry of these radionuclides is very complex and the $K_{d}$ is provided as a general indicator of soil binding and migration potential. $K_{d}$ values are summarized for freshwater-sediment systems and soil-soil solution systems for this purpose.

Based on $\mathrm{K}_{\mathrm{d}}$ values (Table 2.1 ), ${ }^{90} \mathrm{Sr}$ and $\mathrm{U}$ have the greatest potential of the radionuclides addressed in this report for migration through the soil column. Studies of soil columns from Hanford have shown that most of the ${ }^{90} \mathrm{Sr},{ }^{137} \mathrm{Cs}$, and ${ }^{239,240} \mathrm{Pu}$ has remained in the upper $10 \mathrm{~cm}$ of the soil column with the majority of the inventory found between the surface and $5-\mathrm{cm}$ depth (Price 1991). By design, the soil sampling methodology for the surveillance program takes soil from the upper $2.5 \mathrm{~cm}$ of the soil column and is intended to assess the levels of radionuclides most recently deposited by airborne transport. Historical deposits from either Site operations or atmospheric fallout that have migrated below this sampling depth may still be found in the rooting zone of desert plants used for vegetation sampling and may contribute to radionuclide concentrations found in vegetation.

Vegetation sampling provides a third media for monitoring atmospheric deposition to complement soil and air surveillance. Annual sampling of vegetation monitors contamination accumulated on foliage from atmospheric deposition occurring over the preceding year. Plants may also accumulate radionuclides by absorption from soil or irrigation water. The propensity for plants to accumulate radionuclides from the soil column is expressed by plant:soil concentration ratios (CR), a dimensionless expression of the ratio of a radionuclide concentration in plant material to soil, usually on a dry weight basis. Strontium-90 has the greatest propensity for uptake by plants 
Table 2.1. Dissociation Constants $\left(\mathrm{K}_{\mathrm{d}}\right)$ for Radionuclides in Freshwater and Soil:Soil Solution Mixtures

Radionuclide

\begin{tabular}{|c|c|c|c|c|c|c|}
\hline${ }^{60} \mathrm{Co}$ & ${ }^{90} \mathrm{Sr}$ & ${ }^{137} \mathrm{Cs}$ & $238 U^{(a)}$ & $239,240 \mathrm{Pu}^{(a)}$ & ${ }^{241} \mathrm{Am}$ & Reference \\
\hline \multicolumn{7}{|c|}{ Freshwater Systems (Sediment/Water) } \\
\hline 32,000 & 2400 & 27,000 & -(b) & - & - & Booth (1976) \\
\hline- & - & - & $\begin{array}{l}4160 \text { to } \\
62,500^{(c)}\end{array}$ & $\begin{array}{c}222,000 \text { to } \\
428,000\end{array}$ & $\begin{array}{c}92,000 \text { to } \\
400,000\end{array}$ & $\begin{array}{l}\text { As cited in Poston and } \\
\text { Klopfer (1988) }\end{array}$ \\
\hline- & $\begin{array}{c}1000 \\
(0.9 \text { to } \\
1000)\end{array}$ & 20,000 & - & $\begin{array}{c}100,000 \\
(100 \text { to } \\
10,000,000)\end{array}$ & $\begin{array}{c}400,000 \\
(1000 \text { to } \\
1,000,000)\end{array}$ & Coughtrey et al. 1985 \\
\hline \multicolumn{7}{|c|}{ Terrestrial Systems Soil/Soil Solution } \\
\hline 1000 & - & $\begin{array}{c}1000 \\
(1000 \text { to } \\
10,000\end{array}$ & - & $\begin{array}{c}5000 \\
(18 \text { to } \\
10,000)\end{array}$ & $\begin{array}{c}40,000 \\
(1200 \text { to } \\
8700)\end{array}$ & Coughtrey et al. 1985 \\
\hline
\end{tabular}

(a) Representative radionuclide, other isotopes of these elements would behave similarly.

(b) No value.

(c) Range of reported $\mathrm{K}_{\mathrm{d}}$ values.

(Table 2.2) primarily because of its solubility (low $\mathrm{K}_{\mathrm{d}}$ ) and chemical similarity to Ca. The uptake potential of ${ }^{90} \mathrm{Sr}$ by plants was very apparent in vegetation samples collected from the $100-\mathrm{N}$ shoreline from 1990 through 1992 (Antonio et al. 1993). Concentrations of ${ }^{90} \mathrm{Sr}$ were found as high as $440 \mathrm{pCi} / \mathrm{g}$ in mulberry vegetation (Morus alba). Deep-rooted desert plants have also been known to translocate ${ }^{90} \mathrm{Sr}$ to foliage (Klepper et al. 1979). With the exception of ${ }^{3} \mathrm{H}$, no other radionuclides were accumulated to a significant degree above background levels in shoreline vegetation upstream or downstream of the 100-N Springs site. Contaminated vegetation from the 100-N Springs site was removed in 1992.

Table 2.2. Concentration Ratios (CR) for Radionuclides in Plants (Coughtrey et al. 1985)

\begin{tabular}{|c|c|c|c|c|c|c|}
\hline & \multicolumn{6}{|c|}{ Radionuclide } \\
\hline & ${ }^{60} \mathrm{Co}$ & ${ }^{90} \mathrm{Sr}$ & ${ }^{137} \mathrm{Cs}$ & $238 \mathrm{U}$ & $239,240 \mathrm{Pu}$ & ${ }^{241} \mathrm{Am}$ \\
\hline Best Estimate & --(a) & 5 & 0.25 & -- & 0.07 & 0.01 \\
\hline Range & $-\infty$ & 0.1 to 20 & $\begin{array}{l}0.002 \\
\text { to } 56\end{array}$ & -- & -- & $\begin{array}{l}0.00001 \\
\text { to } 1\end{array}$ \\
\hline
\end{tabular}

(a) No value. 


\subsection{Radiological Considerations}

The approach to measuring radioactivity in environmental samples involves the counting of decay particles in a sample. These counts are compared to background counts to quantify the concentration of a particular radionuclide in a sample. At very low concentrations, as routinely observed in environmental samples, background counts may slightly exceed sample counts. When this happens, the resulting concentration of a radionuclide is expressed as a negative number. This negative value is valid, indicates that the concentration was less than detection, and should be used when determining means, medians, and other useful statistics.

Radiological characteristics of each radionuclide are presented to provide background information about the nuclides of interest and their associated decay modes.

Cobalt-60 is a radioactive isotope of cobalt that has a half-life of 5.2 years. Cobalt-60 is unique in that during its physical beta $\left(B^{-}\right)$decay, two photons are also emitted, both with nearly $100 \%$ abundance. The gamma $(\gamma)$ energies are $1.17 \mathrm{MeV}$ and $1.33 \mathrm{MeV}$. The identification of both photon energy peaks with a ratio of roughly one is expected during sample analysis. During the time span covered by this report, the concentration of ${ }^{60} \mathrm{Co}$ in a static system (no inputs or no losses other than physical decay) would be expected to decrease by a minimum of $75 \%$.

Strontium-90 is a $B^{-}$emitting radionuclide, half-life $=28.8$ years, that decays to ${ }^{90} \mathrm{Y}$ which is also a $\mathrm{B}^{-}$emitter with a much shorter half-life (64 hours). The ${ }^{90} \mathrm{Y} \mathrm{B}^{-}$is much more energetic than the ${ }^{90} \mathrm{Sr} B^{-}$, the maximum energies are 2.28 and $0.54 \mathrm{MeV}$, respectively. During the 11-year course of this study, the amount of ${ }^{90} \mathrm{Sr}$ present in soil or vegetation samples in 1983 would decrease by about $33 \%$ assuming static conditions and radiological decay.

Cesium-137 is a $\mathrm{B}^{-}$emitting radionuclide with a half-life of 30 years. Cesium-137 decays to $137 \mathrm{~m} \mathrm{Ba}$, which in turn, decays to stable ${ }^{137} \mathrm{Ba}$. Barium-137m, half-life $=2.6$ minutes, releases the characteristic $0.662 \mathrm{MeV}$ photon, which is usually associated with ${ }^{137} \mathrm{Cs}$. Since ${ }^{137 \mathrm{mBa}}$ has a short half-life relative to ${ }^{137} \mathrm{Cs}$, secular equilibrium is assumed for analysis by gamma spectroscopy. During the 11-year course of this study, the amount of ${ }^{137} \mathrm{Cs}$ present in 1983 would decrease by about $32 \%$ assuming static conditions and radiological decay.

Uranium is a primordial element and is primarily found as ${ }^{238} \mathrm{U}(99.27 \%$ relative abundance) half-life $=4,510,000,000$ years; ${ }^{235} \mathrm{U}(0.72 \%$ relative abundance $)$, half-life $=710,000,000$ years; and ${ }^{234} \mathrm{U}(0.00057 \%$ relative abundance), half-life $=247,000$ years. Uranium isotopes are primarily alpha $(\alpha)$ emitters. Natural and enriched uranium was used as the fuel for Pu production reactors on the Hanford Site. Fuel rods enriched with ${ }^{235} \mathrm{U}$ supplied neutrons through fission for the activation of ${ }^{238} \mathrm{U}$ to ${ }^{239} \mathrm{U}$. Uranium-239 then decayed $\left(B^{-}\right)$to ${ }^{239} \mathrm{~Np}$, which in turn decayed $\left(B^{-}\right)$to ${ }^{239} \mathrm{Pu}$. Uranium-234 emits a $4.7 \mathrm{MeV} \alpha$ particle, ${ }^{235} \mathrm{U}$ emits $\alpha$ particles with energies at $4.7 \mathrm{MeV}$ and 4.5 $\mathrm{MeV}$, and ${ }^{238} \mathrm{U}$ emits $\alpha$ particles with energies of either $4.2 \mathrm{MeV}$ or $4.15 \mathrm{MeV}$. Because of the long half-lives of $U$ isotopes, radiological decay is not a significant factor in its persistence in soil or vegetation samples over the duration of this study.

Plutonium is predominantly a manmade element. Plutonium-239 is an $\alpha$-emitting radionuclide produced through the neutron activation of uranium. Plutonium-239 decays to ${ }^{235} \mathrm{U}$ with a half-life of 24,400 years. The energy of the $\alpha$ particle is $5.1 \mathrm{MeV}$. Because the alpha energy 
peak for ${ }^{239} \mathrm{Pu}$ is very similar to ${ }^{240} \mathrm{Pu}$, analytical results for both isotopes are reported as $239,240 \mathrm{Pu}$. Plutonium-238 is an $\alpha$-emitting radionuclide with a $5.5 \mathrm{MeV}$ energy and a half-life of 86.4 years. It is a decay product of ${ }^{238} \mathrm{~Np}$ which is generated by neutron capture by ${ }^{237} \mathrm{~Np}$. Because of the long half-life of ${ }^{239} \mathrm{Pu}$, radiological decay was not a significant factor in its persistence in soil or vegetation samples over the duration of this study. Plutonium-238 would decrease about $9.4 \%$ over 11 years because of decay.

Americium-241 is another manmade, $\alpha$-emitting radionuclide produced through the $\beta^{-}$decay of ${ }^{241} \mathrm{Pu}$. Plutonium-241 is produced through multiple neutron captures of ${ }^{238} \mathrm{U}$ or ${ }^{239} \mathrm{Pu}$. The $\alpha$ particles from ${ }^{241} \mathrm{Am}$ are emitted with an energy of approximately $5.4 \mathrm{MeV}$ and a half-life of 458 years. Under static conditions, ${ }^{241}$ Am would decrease in soil and vegetation about $1.6 \%$ over 11 years because of decay. 


\subsection{Sampling and Analysis}

This section discusses sample collection, and radiochemical and statistical analyses of soil and vegetation data.

\subsection{Sample Collection}

The procedures for collecting soil and vegetation samples were consistent for the duration of this study period. All sampling sites were located in undeveloped shrub-steppe areas. Initially, both soil and vegetation samples were collected at each location. There were major interruptions in sampling in 1990 and 1992 because of reprioritization of sampling objectives (Woodruff et al. 1991, $1992,1993)$. Since 1990, vegetation sampling was discontinued at many locations where soil sampling was retained. Over the study period, 26 onsite and 18 offsite locations were sampled (see Figure 2.1); however some locations were only sampled once and only three offsite locations were sampled every year of the study period (Appendix B). The sampling locations were grouped into five study areas: offsite (consisting of as many as 18 locations), the 100 Areas (8 locations), the 200 Areas ( 8 locations), the 300 Area (2 locations) and 600 Area (8 locations). The actual number of locations varied among years. The 100 Areas samples were collected between the $100-\mathrm{K}$ and $100-\mathrm{D}$ Areas and also include the 100 Area Fire Station location. The 600 Area includes sampling locations apart from the defined study areas and includes sampling locations around the 400 Area.

\subsubsection{Soil Sampling}

Soil samples consisted of a composite of five separate plugs, $2.5 \mathrm{~cm}$ deep and $10 \mathrm{~cm}$ in diameter, taken from an area of about $100 \mathrm{~m}^{2}$. Composited soil samples were dried at $105^{\circ} \mathrm{C}$ and passed through a 2-mm sieve prior to analysis for radionuclides. One composite sample was collected from each location except when occasional duplicate samples were also collected for quality control.

\subsubsection{Vegetation Sampling}

Vegetation samples consisted of the current year's growth of shrubs growing on undisturbed land in the immediate vicinity of the soil sampling site. Samples consisted of mixed portions of big sagebrush (Artemisia tridentata) and rabbitbrush (Chrysothamnus sp.) that were collected in amounts proportional to the relative percentage of each species found at the site.

\subsection{Radiochemical Analyses}

Radiochemical analyses of soil and vegetation samples were designed to measure radionuclide concentrations at or below reporting level thresholds for the Hanford Site (DOE 1991).

Concentrations measured in soil and vegetation samples are often close to or below the minimum 
detectable concentrations (MDC). MDCs provided an indication of the sensitivity of the analytical method (Table 3.1); however, MDCs were only contractual guidelines that the analytical facilities were obligated to meet. At times, greater sensitivity was achieved in an analysis, and concentrations were measured at levels below the MDC (e.g., $239,240 \mathrm{Pu}$ in soil).

There were very few changes in analytical methods over the study period for each radionuclide with the exception of $U$. Uranium was analyzed by three different methods in soil: fluorometry, low energy photon spectroscopy (LEPS), and alpha spectroscopy. Results of $U$ determined by fluorometry have been reported as U-Nat (in vegetation) and as U-Total (in soil) in earlier studies and reports. Fluorometry was performed on acid extracts of soil or ashed vegetation. Dried soil samples have been processed by acid leaching and microwave bomb digestion processes; the latter of which was more representative of all $U$ present in the soil matrix (Poston 1990). Alpha spectroscopy and fluorometry were used to measure $U$ in vegetation samples.

The analytical results reported here were provided by two laboratories. Samples collected before June of 1990 were analyzed by U.S. Testing, Inc. (UST), Richland, Washington. Samples collected from 1990 through 1993 were analyzed by International Technology Analytical Services (ITAS), Richland, Washington, which acquired the UST facilities in 1990. The analytical methods used for radio-chemical analyses were summarized by Jaquish and Bryce (1990). All soil and vegetation results were reported as $\mathrm{pCi} / \mathrm{g}$ of dried sample.

\subsection{Data Evaluation}

Radionuclide concentrations were evaluated by study area and used to provide descriptive statistics to characterize the distribution of data for the 11-year study period. Data manipulations and analyses were performed using Microsoft Excel and Statview software.

Table 3.1. MDCs for Radionuclides Addressed in This Report

\begin{tabular}{c} 
Radionuclide \\
\hline${ }^{60} \mathrm{Co}$ \\
${ }^{90} \mathrm{Sr}$ \\
${ }^{137} \mathrm{Cs}$ \\
${ }^{234} \mathrm{U}$ \\
$235 \mathrm{U}$ \\
$235 \mathrm{U}$ \\
$238 \mathrm{U}$ \\
$238 \mathrm{U}$ \\
U-Total \\
$238 \mathrm{Pu}$ \\
$239,240 \mathrm{Pu}$ \\
$241 \mathrm{Am}$ \\
\hline
\end{tabular}

\begin{tabular}{c} 
Method \\
\hline Gamma Spectroscopy \\
Radio-Chemical \\
Gamma Spectroscopy \\
Alpha Spectroscopy \\
Alpha Spectroscopy \\
Low Energy Photon \\
Alpha Spectroscopy \\
Low Energy Photon \\
Fluorometric Analysis \\
Alpha Spectroscopy \\
Alpha Spectroscopy \\
Alpha Spectroscopy
\end{tabular}

\begin{tabular}{|c|c|}
\hline \multicolumn{2}{|c|}{ Soil } \\
\hline Aliquot (g) & $\mathrm{MDC}(\mathrm{pCi} / \mathrm{g}$ \\
\hline $150-500$ & 0.02 \\
\hline 100 & 0.005 \\
\hline $150-500$ & 0.02 \\
\hline 500 & 0.02 \\
\hline 500 & 0.02 \\
\hline 100 & 1.0 \\
\hline 500 & 0.02 \\
\hline 100 & 1.0 \\
\hline 50 & 0.01 \\
\hline 1 & 0.0006 \\
\hline 1 & 0.0006 \\
\hline 10 & 0.05 \\
\hline
\end{tabular}

\begin{tabular}{cc}
\multicolumn{2}{c}{ Vegetation } \\
\hline Aliquot (g) & MDC (pCi/g) \\
\hline 125 & 0.03 \\
100 & 0.005 \\
125 & 0.03 \\
100 & 0.1 \\
100 & 0.1 \\
$\mathrm{NA}^{(\mathrm{a})}$ & \\
100 & 0.1 \\
$\mathrm{NA}$ & \\
10 & 0.01 \\
100 & 0.0006 \\
100 & 0.0006 \\
$\mathrm{NS}^{(b)}$ &
\end{tabular}

(a) NA $=$ Not analyzed.

(b) NS = Not sampled. 
Data are graphically presented as three-dimensional histograms with the median concentrations reported by study area and year. All plotted median concentrations are based on a minimum of two samples per location per year (i.e., years with only one sample per study area are not presented in the figures because that situation may introduce a bias). Radionuclides were not evaluated when data sets (organized by study area and radionuclide) contained a large proportion of negative values or values that were below detection (i.e., high associated analytical or counting error). This condition was prevalent for a number of gamma emitting radionuclides (e.g., ${ }^{65} \mathrm{Zn},{ }^{58} \mathrm{Co}$ ), as well as ${ }^{238} \mathrm{Pu}$ in vegetation. Additionally, box plots have been developed and placed in Appendix $\mathrm{C}$ for further review. Box plots provide significantly more information about data distribution by study area, but with 11 years of data grouped into 5 study areas, they are very complex and require rigorous inspection.

Descriptive statistics area summarized by study area for each radionuclide. These statistics have been evaluated to provide a generalized ranking of the study areas from those with the highest concentrations to those with the lowest concentrations

\subsection{Statistical Analysis}

Parametric statistical analyses were used to evaluate differences between study areas and trends in soil and vegetation concentrations of radionuclides. Generally, radionuclide concentrations are log-normally distributed in soil and vegetation samples (Eberhardt and Gilbert 1980), i.e., the data are generally skewed, but a log-transformation will produce a more normal bell-shaped distribution. Distributions of log-transformed and non-transformed data for soil and vegetation results grouped by area were compared to determine if log-transformation was appropriate. In nearly all cases, log-transformation produced a more normal distribution of data than the non-transformed data. Negative values are lost when a log-transformation is applied to the data; hence, biases can be introduced into the evaluation. To alleviate this problem, a small incremental constant was added to each datum to slightly shift the distribution so that all data points were positive to allow for complete transformation of all the data for evaluating study area differences (Gilbert and Kinnison 1981). When the data bases for a particular radionuclide contained a relatively large percentage of negative values, statistical analyses were not performed (e.g., ${ }^{60} \mathrm{Co}$ in vegetation and ${ }^{241} \mathrm{Am}$ in soil). Statistical analyses perfomed on soil and vegetation data are smmarized in Table 3.2

\subsubsection{Spacial Differences}

The statistical analyses for study area effects involved analysis of variance (ANOVA) by area of log-transformed data. When the ANOVA was significant, differences in log-transformed mean soil concentrations were determined with Scheffé's post hoc multiple comparison. Scheffé's F-test is a post hoc comparison that is very robust to violations of the assumptions typically associated with multiple comparison procedures, such as unequal sample sizes and heterogeneous variances. For these comparisons, the data were classified as offsite, 100 Areas, 200 Areas, 300 Area, and 600 Area (see Figure 2.1). Year effects were not factored into the ANOVA because of the interruption of sample analyses in 1990 and 1991. In some instances, comparisons were also made for data grouped by analytical laboratory; i.e., pre-1990 samples were analyzed by UST and samples collected in 1990 and afterwards were analyzed by ITAS. 
Table 3.2. Summary of Statistical Analyses Performed on Soil and Vegetation Data

\begin{tabular}{|c|c|c|c|c|c|c|}
\hline \multirow[b]{2}{*}{$\underline{\text { Radionuclide }}$} & \multicolumn{3}{|c|}{ Soil } & \multicolumn{3}{|c|}{ Vegetation } \\
\hline & $\begin{array}{c}\text { Qualitative } \\
\text { Ranking } \\
\end{array}$ & Spacial & Trend & $\begin{array}{l}\text { Qualitative } \\
\text { Ranking }\end{array}$ & Spacial & Trend \\
\hline${ }^{60} \mathrm{Co}$ & $\sqrt{ }(a)$ & ANOVA $^{(b)}$ & $N A^{(c)}$ & $\checkmark$ & NA. & NA \\
\hline${ }^{90} \mathrm{Sr}$ & $\sqrt{ }$ & ANOVA & Regres. ${ }^{(d)}$ & $\sqrt{ }$ & ANOVA & Regres. \\
\hline${ }^{137} \mathrm{Cs}$ & $\sqrt{ }$ & ANOVA & Regres. & $\sqrt{ }$ & ANOVA & Regres. \\
\hline U-Total & $\sqrt{ }$ & ANOVA & NA & $\sqrt{ }$ & ANOVA & NA \\
\hline${ }^{238} \mathrm{Pu}$ & $\sqrt{ }$ & ANOVA & Regres. & NA & NA & NA \\
\hline $239,240 \mathrm{Pu}$ & $\sqrt{ }$ & ANOVA & Regres. & $\checkmark$ & ANOVA & Regres. \\
\hline${ }^{241} \mathrm{Am}$ & NA & $\mathrm{NA}$ & NA & NA & NA & NA \\
\hline
\end{tabular}

(a) Study areas are ranked by generally decreasing radionuclide concentrations.

(b) Analysis of Variance of log transformed data.

(c) NA = Not analyzed.

(d) Linear regression analysis of log transformed median concentrations.

\subsubsection{Trend Effects}

Trends of radionuclide concentrations were evaluated by conducting ANOVA and Model I (simple) regressions of log-transformed median values, by year, for data grouped by study area (Sokal and Rohlf 1981). Use of log-transformed median concentrations account for central tendency of the data. All median concentrations were positive, hence no incremental constants were added as was done for ANOVA procedures. Years where only one sample was collected from a study area were not used in the regression analysis. 


\subsection{Results and Discussion}

This section evaluates the spatial distribution and trends of ${ }^{60} \mathrm{Co},{ }^{90} \mathrm{Sr},{ }^{137} \mathrm{Cs}, \mathrm{U}$ isotopes, and $\mathrm{Pu}$ isotopes in soil and vegetation samples. Americium-241 was also evaluated; however, it was measured in a small group of soil samples. Tables and figures documenting statistical analyses and box plots are located in Appendix C. Generally, soil sampling activities increased slightly from 1983 through 1989, and were curtailed in 1990 and 1991 and resumed at a modest effort in 1992 and 1993 (Woodruff et al. 1991, 1992, 1993). Vegetation sampling followed a similar pattern; however, vegetation sampling was more significantly curtailed from 1990 through 1993 (see Appendix B).

\subsection{Cobalt-60}

Cobalt- 60 was measured in all soil and vegetation samples collected over the study period. Many measurements, however, were below the MDC of $0.02 \mathrm{pCi} / \mathrm{g}$ dry weight for soil and vegetation samples. This was most notable for samples collected towards the end of the study period. Consequently, only area differences are addressed for ${ }^{60} \mathrm{Co}$ in this report. The 100 Areas have consistently had the highest reported atmospheric releases throughtout the study period (Figure A.1); however, the maximum annual release was $1.0 \mathrm{Ci} / \mathrm{y}$ in 1989.

\subsubsection{Soil}

Soil samples were collected for gamma spectral analysis of ${ }^{60} \mathrm{Co}$ from 1983 through 1993. During this time, individual results ranged from $-0.047( \pm 0.034)^{(a)}$ to $0.28( \pm 0.039) \mathrm{pCi} / \mathrm{g}{ }^{60} \mathrm{Co}$. The maximum concentration was reported from the 100 Areas in 1991 (Table $4.1^{\circ}$ and Figure C.2). Within the 100 Areas, especially along the Columbia River shoreline and on some islands, specific locations have been documented to have above background levels of ${ }^{60} \mathrm{Co}$ in the form of discrete radioactive particles (Cooper and Woodruff 1993; Sula 1980).

Table 4.1. Descriptive Statistics for ${ }^{60} \mathrm{Co}(\mathrm{pCi} / \mathrm{g})$ in Soil (1983 Through 1993)

\begin{tabular}{|c|c|c|c|c|c|}
\hline . & 100 Areas & 200 Areas & 300 Area & 600 Area & Offsite \\
\hline Median & 0.020 & 0.000 & -0.001 & 0.001 & 0.001 \\
\hline Mean & 0.032 & 0.001 & -0.003 & 0.001 & 0.002 \\
\hline Standard Error & 0.009 & 0.002 & 0.004 & 0.002 & 0.001 \\
\hline Standard Deviation & 0.053 & 0.017 & 0.016 & 0.016 & 0.016 \\
\hline Variance $^{(a)}$ & 0.003 & 0.000 & 0.000 & 0.000 & 0.000 \\
\hline Minimum & -0.038 & -0.047 & -0.047 & -0.031 & -0.046 \\
\hline Maximum & 0.280 & 0.050 & 0.028 & 0.063 & 0.062 \\
\hline Count & 35 & 65 & 18 & 62 & 154 \\
\hline
\end{tabular}

(a) Values $=0.000$ indicate variance estimates were $<0.0005$

(a) The value in parentheses is the associated $2 \sigma$ analytical error or the sample result. 


\subsubsection{Spacial Differences}

Median concentrations of ${ }^{60} \mathrm{Co}$ were essentially 0.00 in all areas except the 100 Areas where the median value was $0.02 \mathrm{pCi} / \mathrm{g}$ dry weight (Table 4.1). The general distribution by study area was 100 Areas $>200$ Areas $=300$ Area $=600$ Area $=$ offsite (Figures 4.1 and C.2).

The ${ }^{60} \mathrm{Co}$ data were log-transformed $(\mathrm{pCi} / \mathrm{g}+0.05)$ and an ANOVA was performed to evaluate study area differences. Study area differences were significant, $\mathrm{P}=<0.0001$ (Table C.1). The log-transformed data were subjected to Scheffé's F-test to distinguish any pair-wise differences between study area classification. Cobalt- 60 concentrations in soil samples collected from the 100 Areas were statistically greater than ${ }^{60}$ Co concentrations from all other study areas sampled $(\mathrm{P}<0.01$; Table C.2). The data were not separated by sampling year to evaluate study area differences. Most of the 100 Areas sampling locations are situated around the $100-\mathrm{N}$ Area. The N-Reactor was the last production reactor to operate as the other reactor areas were closed down between 1965 and 1971. Because of ${ }^{60} \mathrm{Co}$ 's relatively short half-life (5.2 year), it is not surprising that concentrations at other study areas were essentially below detection levels (see Table 4.1).

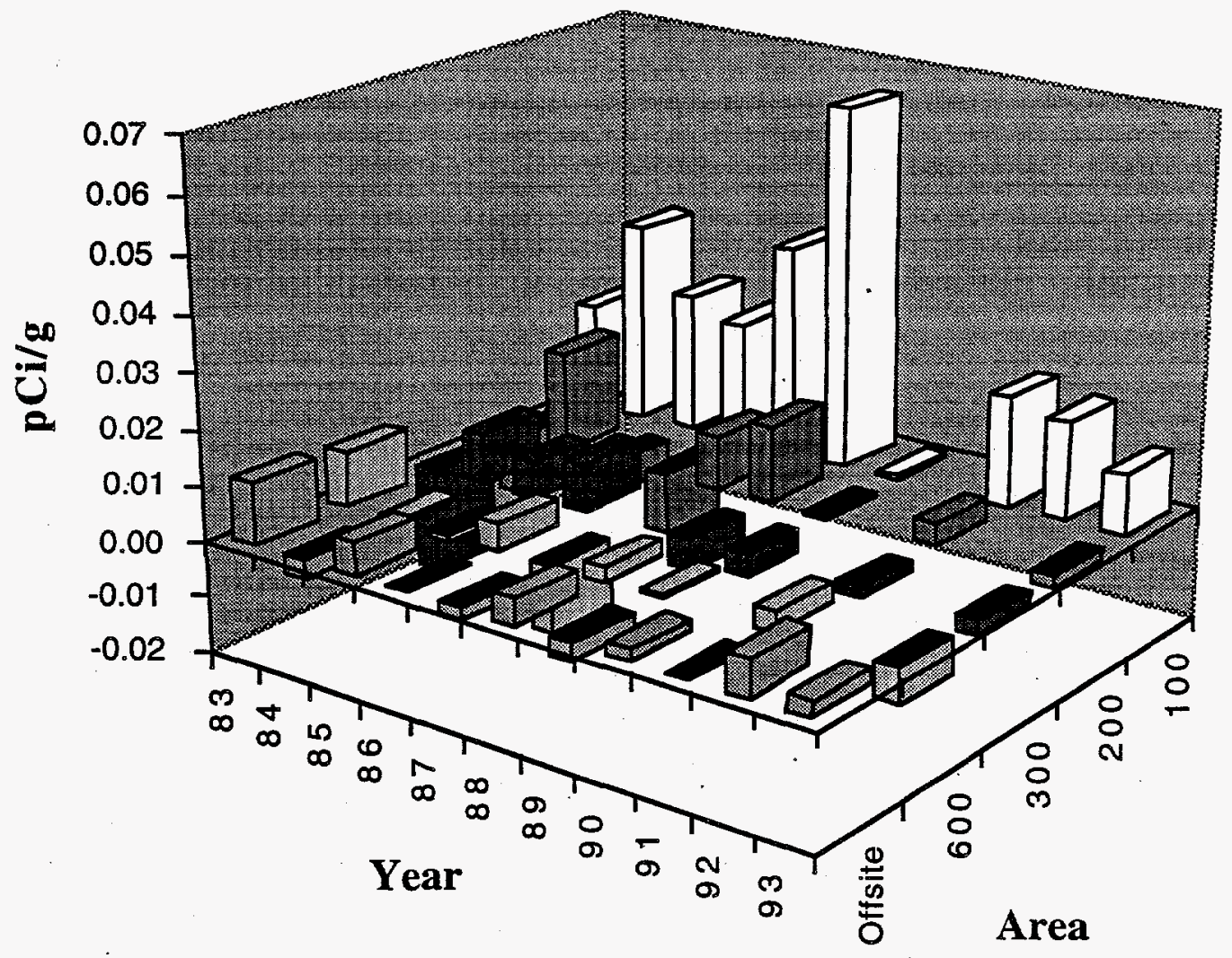

Figure 4.1. Annual Median Concentrations of ${ }^{60} \mathrm{Co}$ in Soil by Study Area. Black tops on histograms indicate a negative median; spaces where boxes are missing indicate less than two locations sampled. 


\subsubsection{Trends}

No trend analyses were performed on the log-transformed ${ }^{60} \mathrm{Co}$ soil data because all measurable concentrations were found in the 100 Areas and all were near the MDC.

\subsubsection{Vegetation}

Vegetation samples were collected for gamma spectral analysis from 1983 through 1993. During this time, the individual results ranged from $-0.08( \pm 0.03)$ to $0.87( \pm 0.06) \mathrm{pCi} / \mathrm{g}{ }^{60} \mathrm{Co}$ dry weight. The maximum concentration was reported from the 100 Areas in 1986 (Table 4.2 and Figure C.3). Within the 100 Areas, especially along the Columbia.River shoreline near $100-\mathrm{N}$, species of riparian plants collected from 1990 through 1992 contained slightly elevated concentrations of ${ }^{60} \mathrm{Co}$ (Antonio et al. 1993). Because most measured concentrations were below detection, no statistical analyses were performed for study area differences.

\subsubsection{Spacial Differences}

The majority of analyses indicated that ${ }^{60} \mathrm{Co}$ concentrations were below the limit of detection $(0.02 \mathrm{pCi} / \mathrm{g}$ dry weight) in vegetation (Figure 4.2$)$. The general distribution by study area was 100 Areas $>200$ Areas $=300$ Area $=600$ Area $=$ offsite $($ Table 4.2). The median concentration was less than detection in all areas and no statistical analysis was performed; however, the distribution of maximum, mean, and median concentrations all indicate that the 100 Areas have the highest concentrations.

\subsubsection{Trends}

No trend analyses were performed on the ${ }^{60} \mathrm{Co}$ vegetation data because the majority of the concentrations were below the MDC.

Table 4.2. Descriptive Statistics for ${ }^{60} \mathrm{Co}(\mathrm{pCi} / \mathrm{g}$ ) in Vegetation (1983 Through 1993)

\begin{tabular}{|c|c|c|c|c|c|}
\hline & 100 Areas & 200 Areas & 300 Area & 600 Area & Offsite \\
\hline Median & 0.018 & -0.001 & 0.001 & 0.003 & 0.002 \\
\hline Mean & 0.092 & -0.003 & 0.008 & -0.001 & 0.002 \\
\hline Standard Error & 0.036 & 0.002 & 0.007 & 0.003 & 0.001 \\
\hline Standard Deviation & $0: 185$ & 0.012 & 0.034 & 0.020 & 0.014 \\
\hline Variance $^{(a)}$ & 0.034 & 0.000 & 0.001 & 0.000 & 0.000 \\
\hline Minimum & -0.015 & -0.037 & -0.018 & -0.078 & -0.050 \\
\hline Maximum & 0.865 & 0.021 & 0.148 & 0.037 & 0.039 \\
\hline Count & 26 & 57 & 21 & 40 & 152 \\
\hline
\end{tabular}

(a) Values $=0.000$ indicate variance estimates were $<0.0005$. 


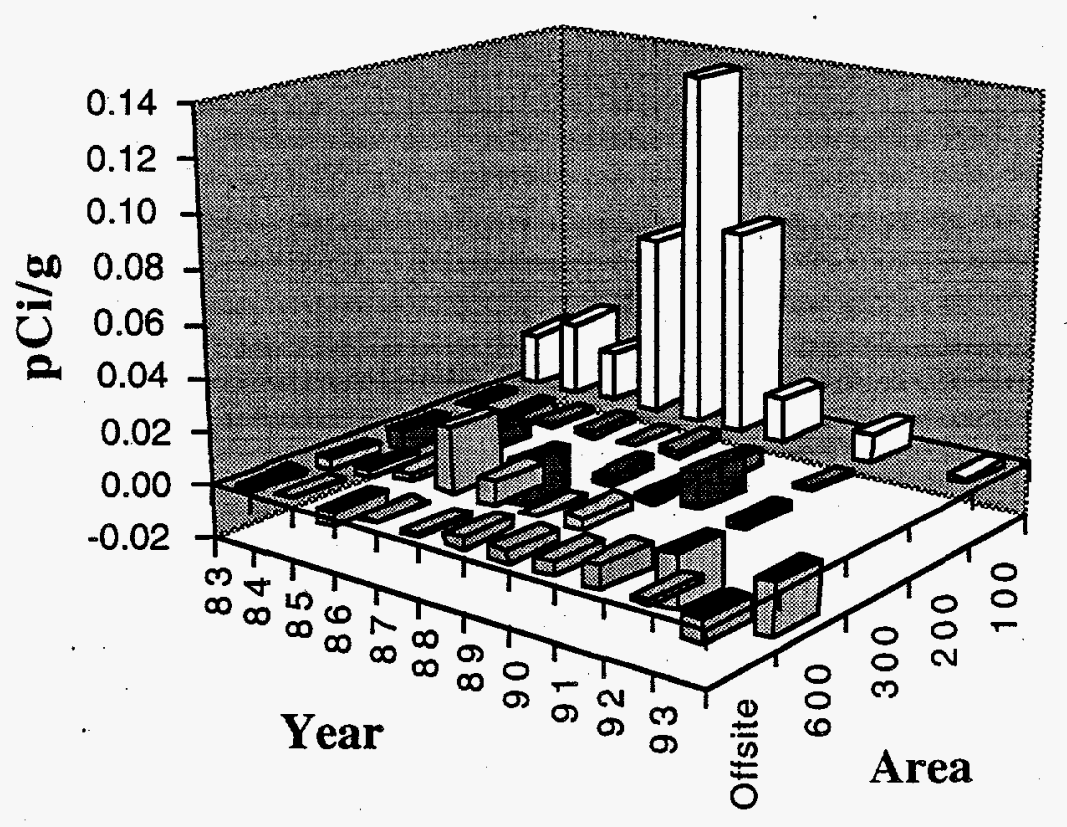

Figure 4.2. Annual Median Concentrations of ${ }^{60} \mathrm{Co}$ in Vegetation by Study Area. Black tops on histograms indicate a negative median; spaces where boxes are missing indicate less than two locations sampled.

\subsection{Strontium-90}

Strontium-90 was readily measured in soil and vegetation samples throughout the study period. The patterns of ${ }^{90} \mathrm{Sr}$ in vegetation and soil on and off the Site were similar with concentrations of ${ }^{90} \mathrm{Sr}$ in soil slightly higher than in vegetation when expressed on a dry weight basis. Study area differences and trends were evaluated in both soil and vegetation samples. The 200 Areas had the highest reported annual releases in 8 out of 11 years from 1983 through 1993 (Figure A.2).

\subsubsection{Soil}

With an MDC of $0.005 \mathrm{pCi} / \mathrm{g}$ dry weight and historical contributions to the environment from atmospheric fallout, ${ }^{90} \mathrm{Sr}$ was readily detected in all soil samples collected on and off the Site. Strontium-90 concentrations ranged from $0.020( \pm 0.008)$ to $2.72( \pm 0,046) \mathrm{pCi} / \mathrm{g}$ dry weight onsite and $0.011( \pm 0.006)$ to $2.31( \pm 0.039) \mathrm{pCi} / \mathrm{g}$ offsite. Median concentrations in all study areas generally declined during the study period (Figures 4.3 and C.4). 


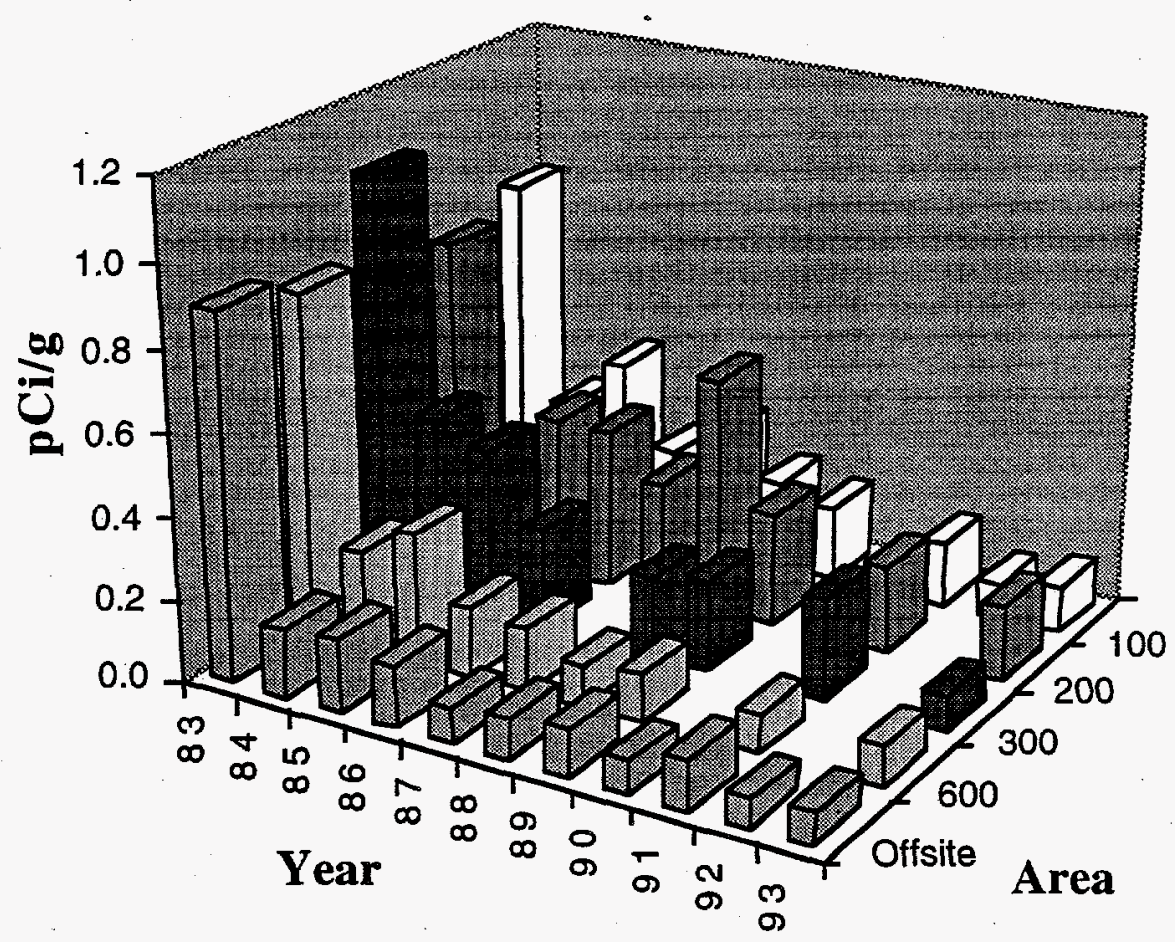

Figure 4.3. Annual Median Concentrations of ${ }^{90} \mathrm{Sr}$ in Soil by Study Area. Spaces' where boxes are missing indicate less than two locations sampled.

\subsubsection{Spaciäl Differences}

Strontium-90 concentrations in soils were highest in the 200 Areas and lowest in offsite samples (Table 4.3). The distribution by study area was 200 Areas $>300$ Area $>100$ Areas $>600$ Area $>$ offsite. Median concentrations in all areas were distinctly higher in 1983 compared to subsequent years. The 200 Areas, specifically the East of the 200-West Gate location (Figure 2.1), have historically had the highest concentrations of locations sampled by the site environmental surveillance project. The disparity between mean and median concentrations of ${ }^{90} \mathrm{Sr}$ and distribution of the data by study area indicated the data were log-normally distributed (see Figure C.4).

Table 4.3. Descriptive Statistics for ${ }^{90} \mathrm{Sr}(\mathrm{pCi} / \mathrm{g})$ in Soil Samples (1983 Through 1993)

\begin{tabular}{|c|c|c|c|c|c|}
\hline & 100 Areas & 200 Areas & 300 Area & 600 Area & Offsite \\
\hline Median & 0.219 & 0.372 & 0.296 & 0.158 & $\overline{0.121}$ \\
\hline Mean & 0.348 & 0.499 & 0.358 & 0.284 & 0.193 \\
\hline Standard Error & 0.069 & 0.069 & 0.076 & 0.045 & 0.023 \\
\hline Standard Deviation & 0.409 & 0.556 & 0.312 & 0.352 & 0.291 \\
\hline Variance & 0.167 & 0.309 & 0.098 & 0.124 & 0.085 \\
\hline Minimum & 0.031 & 0.020 & 0.076 & 0.032 & 0.011 \\
\hline Maximum & 1.970 & 2.720 & 1.360 & 1.920 & 2.310 \\
\hline Count & 35 & 65 & 17 & 62 & 154 \\
\hline
\end{tabular}


An ANOVA was performed on the log-transformed ${ }^{90} \mathrm{Sr}$ data to determine if there were any differences among study areas. Study area differences were significant, $\mathrm{P}=<0.0001$ (Table C.3). The log-transformed data were subjected to Scheffé's F-test to distinguish any pair-wise differences between study areas (Table C.4). Statistically significant differences between log-transformed means were found between the offsite areas and the 100 Areas $(P=0.0043), 200$ Areas $(P<0.0001)$, and the 300 Area $(P=0.0154)$. Additionally, the 200 Areas and the 600 Area log-transformed means were significantly different $(P=0.0060)$.

\subsubsection{Trends}

Regression analyses of log-transformed median ${ }^{90} \mathrm{Sr}$ concentrations by year were significant for all study areas $\left(\mathrm{P}<0.05\right.$; Table 4.4). Soil concentrations of ${ }^{90} \mathrm{Sr}$ were significantly elevated in the 200 Areas compared to other study areas, reflecting a historic condition (Heeb 1994) and recent atmospheric releases (see Figure A.2). The regression lines for all five study areas where similar (Figure 4.4). Collectively, all areas showed a similar decrease in ${ }^{90} \mathrm{Sr}$.

The rate of decrease observed in the study areas where the negative regressions were significant is more than can be explained by radioactive decay. Over the 11-year study period, the expected percentage decrease due to decay was about 33\%. Median concentrations in 1983 in all study areas were distinctly higher than 1984 median concentrations (Figure 4.4). Consequently, percentage decreases were calculated for the 11-year and 10-year periods covering 1983 through 1993 and 1984 through 1993 (Table 4.5). The expected percentage decrease for 10 years is $31 \%$. Only in the 200 Areas over the 1984 to 1993 period was the expected decrease commensurate with the monitored decrease of $30.9 \%$. In all other examples, the decreases based on estimated median concentrations exceeded the predicted decreases by factors of 1.7 to 2.8 . Minor releases of ${ }^{90} \mathrm{Sr}$ in the 200 Areas (Table A.2) may have replenished the ${ }^{90} \mathrm{Sr}$ load in 200 Areas surface soil.

Studies on the distribution of ${ }^{90} \mathrm{Sr}$ in soil columns suggest a downward migration in arid soils (Price 1991), however this is a very slow process. Soil cores used in this study were collected near the 200 Areas and from a shrub-steppe area upwind of the Hanford Site. The majority of ${ }^{90} \mathrm{Sr}$ (i.e., $51 \%$ to $74 \%$ ) in $30-\mathrm{cm}$ cores was found in the top $5 \mathrm{~cm}$ of the soil column. However, ${ }^{90} \mathrm{Sr}$ was found as deep as 15 to $17.5 \mathrm{~cm}$. The potential for downward migration of ${ }^{90} \mathrm{Sr}$ was also indicated by the low $\mathrm{K}_{\mathrm{d}}$. Strontium's mobility in the soil column is governed by cationic exchange properties of the soil column. Strontium-90 may also be removed from the soil column by plant uptake.

Table 4.4. Summary of Regression Analysis and ANOVA of Log Median (LM) ${ }^{90} \mathrm{Sr}$ in Soil

\begin{tabular}{|c|c|c|c|c|c|}
\hline \multirow[b]{2}{*}{ Area } & \multirow[b]{2}{*}{ Equation } & \multirow[b]{2}{*}{$\mathrm{R}^{2}$} & \multicolumn{3}{|c|}{ ANOVA } \\
\hline & & & $\underline{\mathrm{DF}}$ & F-Value & P-Value \\
\hline Offsite & $\mathrm{LM}=5.2408-0.0696 *$ Year & 0.5625 & 10 & 11.5728 & 0.0078 \\
\hline 100 Areas & $\mathrm{LM}=6.1355-0.0770 *$ Year & 0.8417 & 10 & 42.5393 & 0.0002 \\
\hline 200 Areas & $\mathrm{LM}=3.2774-0.0429 *$ Year & 0.4744 & 9 & 6.3173 & 0.0402 \\
\hline 300 Area & $\mathrm{LM}=6.5209-0.0808 *$ Year & 0.7888 & 7 & 22.4122 & 0.0032 \\
\hline 600 Area & $\mathrm{LM}=6.2574-0.0802 *$ Year & 0.7041 & 8 & 16.6560 & 0.0047 \\
\hline
\end{tabular}




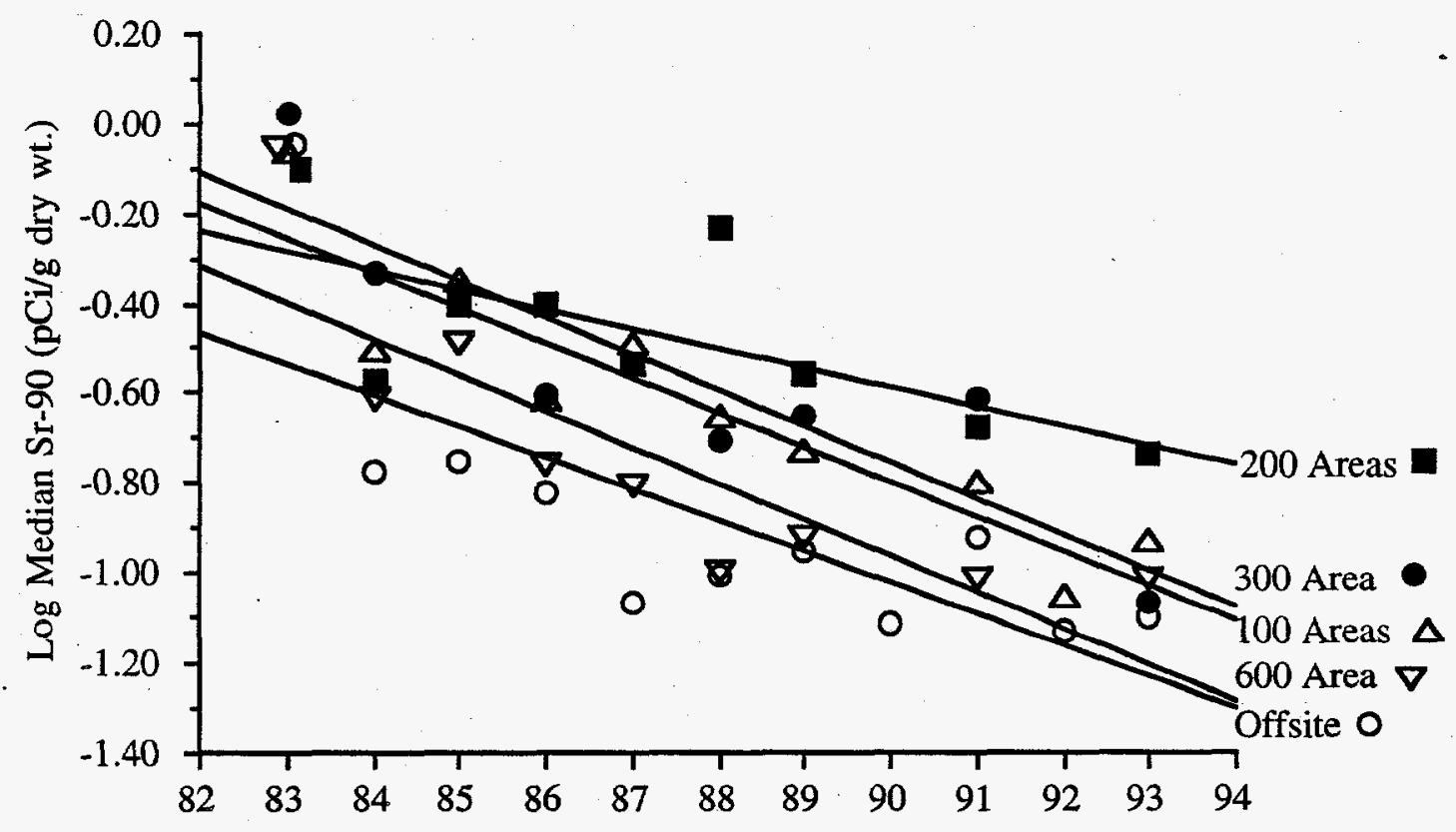

Figure 4.4. Regression Analysis of ${ }^{90} \mathrm{Sr}$ in. Soil by Study Area

Table 4.5. Percentage Decrease of ${ }^{90} \mathrm{Sr}$ in Soil Samples (1983 Through 1993)

\begin{tabular}{|c|c|c|c|c|c|c|c|}
\hline \multirow[b]{2}{*}{ Area } & \multicolumn{3}{|c|}{ Median Concentration $(\mathrm{pCi} / \mathrm{g})$} & \multicolumn{2}{|c|}{ Decrease $(\mathrm{pCi} / \mathrm{g})$} & \multicolumn{2}{|c|}{ Percentage Decrease } \\
\hline & 1983 & $\underline{1984}$ & 1993 & $1983-93$ & $1984-93$ & $1983-93$ & $1984-93$ \\
\hline Offsite & 0.897 & $\overline{0.167}$ & 0.080 & 0.817 & 0.087 & 91.1 & 52.0 \\
\hline 100 Areas & 0.852 & 0.309 & 0.116 & 0.736 & 0.193 & 86.4 & 62.4 \\
\hline 200 Areas & 0.793 & 0.265 & 0.183 & 0.610 & 0.082 & 76.9 & 30.9 \\
\hline 300 Area & 1.047 & 0.464 & 0.085 & 0.962 & $0.379^{\circ}$ & 91.9 & 81.7 \\
\hline 600 Area & 0.849 & 0.241 & 0.096 & 0.753 & 0.145 & 88.7 & 60.2 \\
\hline
\end{tabular}

\subsubsection{Vegetation}

Strontium-90 concentrations in vegetation ranged from $0.008( \pm 0.004)$ to $8.22( \pm 1.54)$ $\mathrm{pCi} / \mathrm{g}$ dry weight onsite and $-0.006( \pm 0.017)$ to $1.06( \pm 0.033) \mathrm{pCi} / \mathrm{g}$ offsite (Table 4.6$)$. The results for vegetation are indicative of atmospheric deposition and transfer from the soil to actively growing vegetation, i.e., each sample consists primarily of the leafy portion.for that year's growing season. The concentration ratios for ${ }^{90} \mathrm{Sr}$ in plants (see Table 2.2) suggest that uptake from soil may be the most significant vector of accumulation in foliage as the estimated current atmospheric releases at the Site are quite low (Figure A.2). 
Table 4.6. Descriptive Statistics for ${ }^{90} \mathrm{Sr}(\mathrm{pCi} / \mathrm{g})$ in Vegetation (1983 Through 1993)

\begin{tabular}{|c|c|c|c|c|c|}
\hline & 100 Areas & 200 Areas & 300 Area & $\underline{600 \text { Area }}$ & Offsite \\
\hline Median & 0.071 & 0.169 & 0.065 & 0.046 & $\overline{0.046}$ \\
\hline Mean & 0.176 & 0.413 & 0.139 & 0.157 & 0.085 \\
\hline Standard Error & 0.086 & 0.146 & 0.048 & 0.051 & 0.016 \\
\hline Standard Deviation & 0.432 & 1.096 & 0.216 & 0.319 & 0.188 \\
\hline Variance & 0.187 & 1.201 & 0.047 & 0.102 & 0.035 \\
\hline Minimum & 0.010 & 0.026 & 0.008 & 0.012 & -0.006 \\
\hline Maximum & 2.210 & 8.220 & 0.934 & 1.680 & 1.060 \\
\hline Count & 25 & 56 & 20 & 39 & 141 \\
\hline
\end{tabular}

\subsubsection{Spacial Differences}

The highest ${ }^{90} \mathrm{Sr}$ concentrations observed during the study period were in samples collected from the 200 Areas. Based on a comparison of median concentrations, the relative concentrations by study area was 200 Areas $>100$ Areas $=300$ Area $>600$ Area $=$ offsite (Figure 4.5 and Table 4.6). In a special study of Columbia River shoreline vegetation (Antonio et al. 1993), concentrations of ${ }^{90} \mathrm{Sr}$ ranged from $0.002( \pm 0.003)$ to $440( \pm 85) \mathrm{pCi} / \mathrm{g}$ dry weight in mulberry leaves. These samples were collected at the 100-N Springs shoreline. The 100-N shoreline was the only shoreline location that indicated an accumulation of ${ }^{90} \mathrm{Sr}$ exceeding upstream reference locations. The source of the ${ }^{90} \mathrm{Sr}$ in the mulberry leaves was contaminated ground water.

The ${ }^{90} \mathrm{Sr}$ data were log-transformed $(\mathrm{pCi} / \mathrm{g}+0.007)$ and an ANOVA performed to evaluate study area differences was highly significant (Table C.5; $\mathrm{P}<0.0001$ ). The log-transformed data were subjected to Scheffé's F-test to distinguish any.pair-wise differences between the log-transformed means by study area (Table C.6). Statistically significant differences between the log-transformed means were found between the 200 Areas and all other areas $(P<0.01)$. This observation is consistant with past and recent atmospheric release estimates of ${ }^{90} \mathrm{Sr}$ for the Site (Figue A.2).

\subsubsection{Trends}

The significant negative regressions of log-median ${ }^{90} \mathrm{Sr}$ concentrations in soil over time were also observed in vegetation samples; however the vegetation data were more variable than the soil data. Only the regressions for the 200 Areas and the offsite locations were significant $(P<0.05$; Table 4.7). Strontium-90 in vegetation appeared to decrease in all study areas (Figure 4.6). The regression analyses may be biased by the reduction in vegetation sampling from 1990 through 1993. 


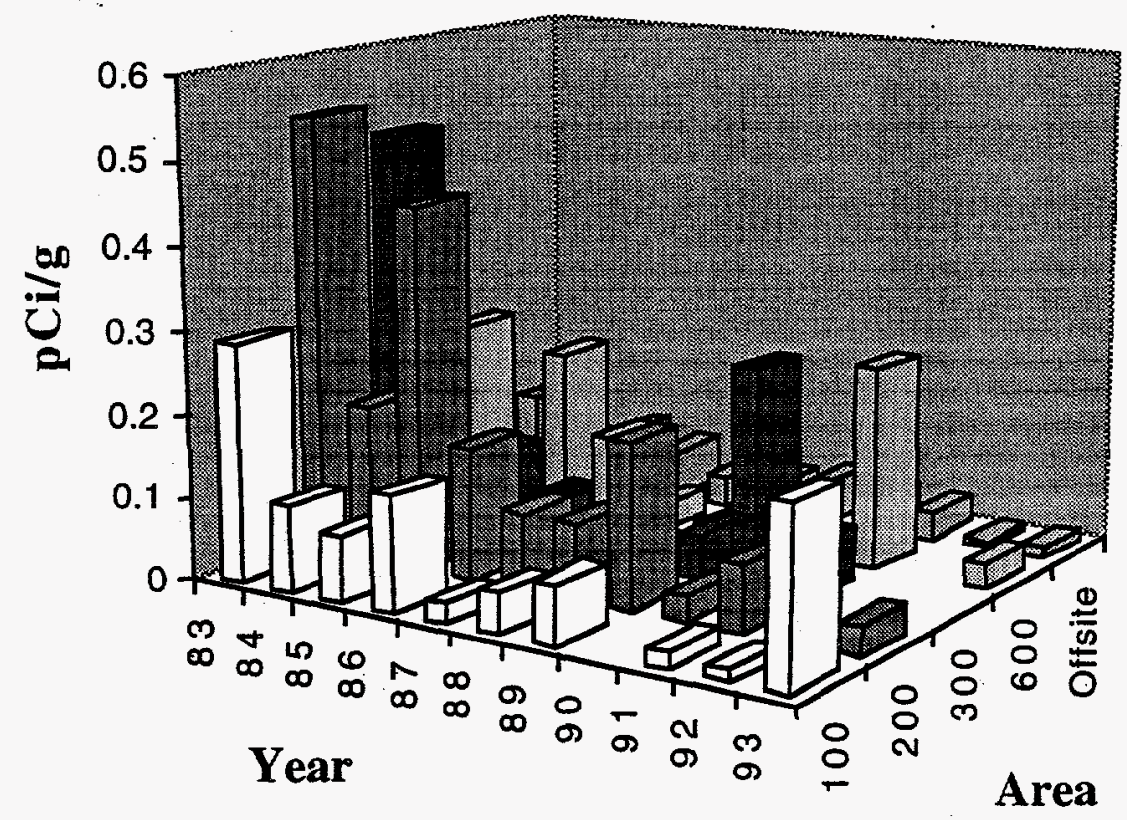

Figure 4.5. Annual Median Concentrations of ${ }^{90} \mathrm{Sr}$ in Vegetation by Study Area. Spaces where boxes are missing indicate less than two locations sampled.

Table 4.7. Summary of Regression Analysis and ANOVA of Log Median (LM) ${ }^{90} \mathrm{Sr}$ in Vegetation

\begin{tabular}{l} 
Area \\
\hline Offsite \\
100 Areas \\
200 Areas \\
300 Area \\
600 Area
\end{tabular}

\begin{tabular}{l} 
Equation \\
\hline LM $=5.5820-0.0795 *$ Year \\
LM $=1.8096-0.0334 *$ Year \\
LM $=6.7387-0.0864 *$ Year \\
LM $=1.8590-0.0337 *$ Year \\
LM $=3.1010-0.0485 *$ Year
\end{tabular}

\begin{tabular}{l}
$\mathrm{R}^{2}$ \\
\hline 0.7093 \\
0.0787 \\
0.5591 \\
0.0488 \\
0.1429
\end{tabular}

\begin{tabular}{l}
\hline$\underline{\mathrm{DF}}$ \\
10 \\
8 \\
7 \\
7 \\
8
\end{tabular}

\begin{tabular}{|c|c|}
\hline F-Value & P-Value \\
\hline 21.9635 & 0.0011 \\
\hline 0.5980 & 0.4647 \\
\hline 7.6092 & 0.0329 \\
\hline 0.3078 & 0.5991 \\
\hline 1.1674 & 0.3157 \\
\hline
\end{tabular}




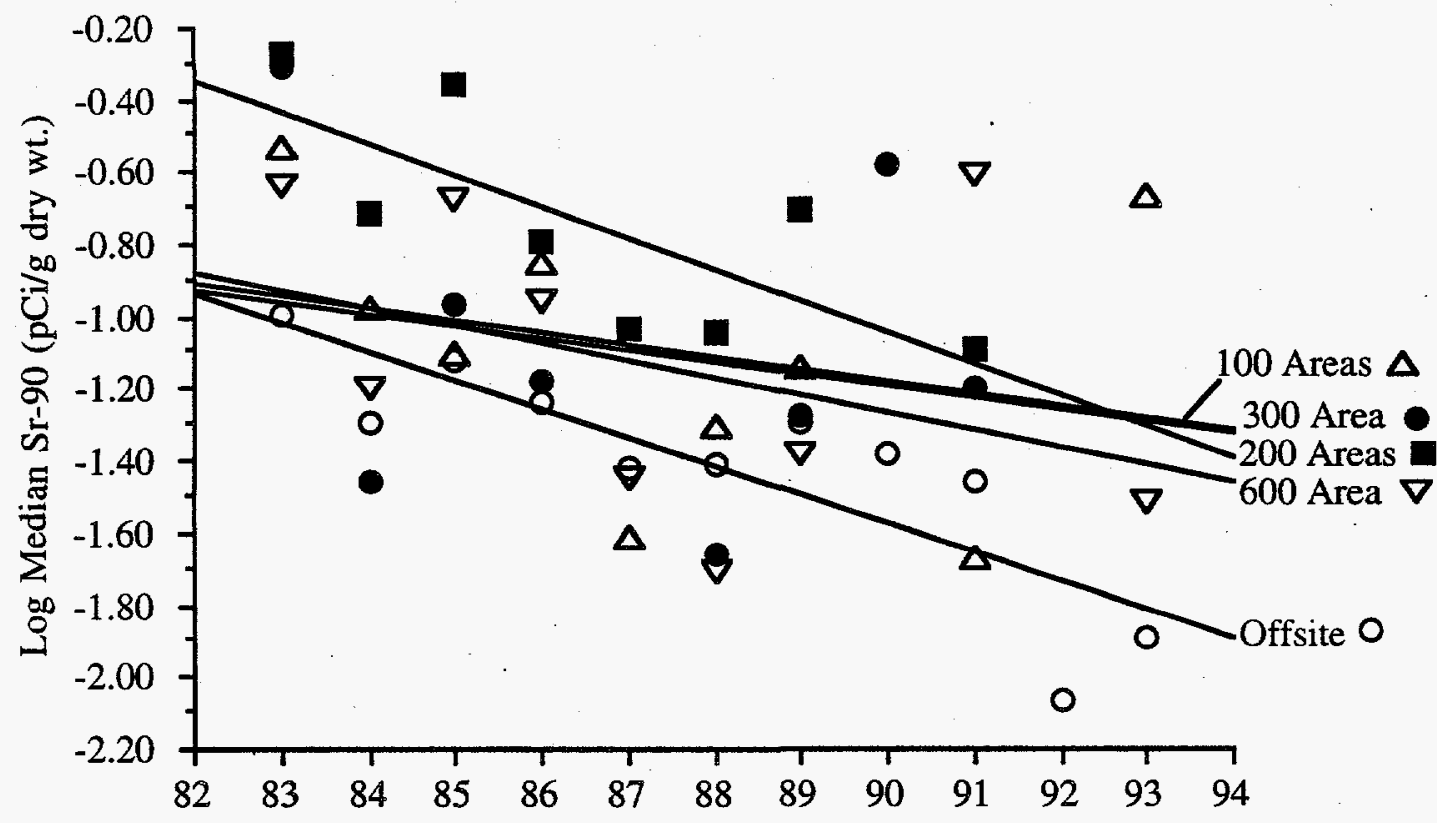

Figure 4.6. Regression Analysis of ${ }^{90} \mathrm{Sr}$ in Vegetation by Study Area

\subsection{Cesium-137}

Cesium-137 was detected in all soil samples and about $30 \%$ of the vegetation samples collected over the study period. Generally, concentrations in soil run an order of magnitude higher than vegetation on a dry weight basis. In 1986 and 1987, releases from the Chernobyl accident were detected in soil and vegetation samples. Annual releases where highest in the 200 Areas in 10 of the 11 years covered in this report (Figure A.3). The MDC for ${ }^{137} \mathrm{Cs}$ was $0.02 \mathrm{pCi} / \mathrm{g}$ for soil and vegetation.

\subsubsection{Soil}

Cesium-137 concentrations ranged from a maximum of $28.1( \pm 0.33) \mathrm{pCi} / \mathrm{g}$ in the 200 Areas in 1983 to a low of $-0.002( \pm 0.039) \mathrm{pCi} / \mathrm{g}$ dry weight measured at Moses Lake (Table 4.8). This Moses Lake soil sample was the only sample collected with a concentration less than the detection limit.

\subsubsection{Spacial Differences}

The maximum ${ }^{137} \mathrm{Cs}$ concentration was reported from around the 200 Areas in 1983; however, the study area with the highest median concentration was the 100 Areas (Figure 4.7). Cesium-137 was most variable in the 200 Areas where the highest concentrations were found (Table 4.8). The general pattern of concentrations based on mean, median, maximum, and variance estimates, however, was 100 Areas $=200$ Areas $=300$ Area $>600$ Area $=$ offsite locations. 
Table 4.8. Descriptive Statistics for ${ }^{137}$ Cs in Soil (1983 Through 1993)

\begin{tabular}{|c|c|c|c|c|c|}
\hline & 100 Areas & 200 Areas & 300 Area & 600 Area & Offsite \\
\hline Median & 0.762 & 0.587 & 0.695 & 0.366 & 0.425 \\
\hline Mean & 0.779 & 3.307 & 0.725 & 0.506 & 0.517 \\
\hline Standard Error & 0.056 & 0.804 & 0.074 & 0.050 & 0.033 \\
\hline Standard Deviation & 0.332 & 6.482 & 0.313 & 0.394 & 0.414 \\
\hline Variance & 0.110 & 42.012 & 0.098 & 0.155 & 0.172 \\
\hline Minimum & 0.110 & 0.011 & 0.159 & 0.044 & -0.002 \\
\hline Maximum & 1.580 & 28.100 & 1.230 & 1.560 & 2.180 \\
\hline Count & 35 & 65 & 18 & 62 & 154 \\
\hline
\end{tabular}

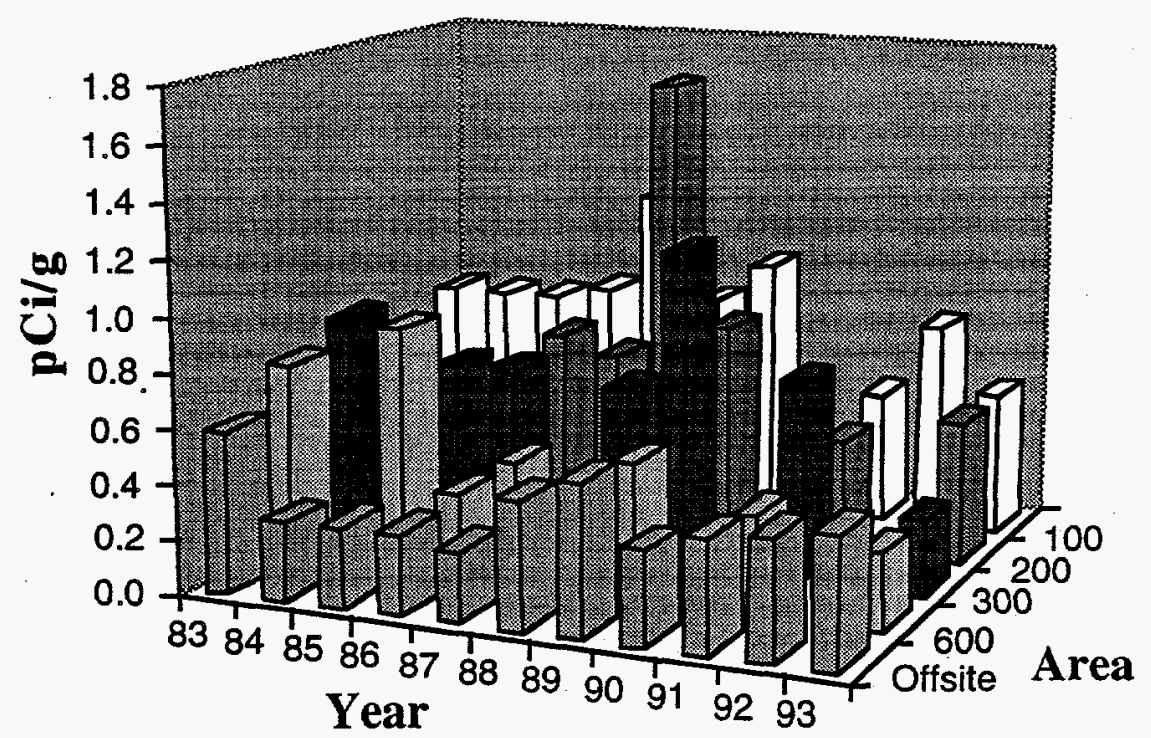

Figure 4.7. Annual Median Concentrations of ${ }^{137} \mathrm{Cs}$ in Soil by Study Area

The data were also transformed $(\log \mathrm{pCi} / \mathrm{g}+0.002)$ and an ANOVA performed to evaluate study area differences was significant, $\mathrm{P}=<0.0001$ (Table C.7). The log-transformed data were subjected to Scheffé's F-test to distinguish any pair-wise differences between study areas. Statistically significant differences were found between the 100 Areas and the offsite locations; the 200 Areas and the 600 Area; and the 200 Areas and the offsite locations; P values were $0.046,0.0016,<0.0001$, respectively (Table C.8). The influence of the Chernobyl releases was not very noticable in soil samples because it was masked by background concentrations on and off the Site.

\subsubsection{Trends}

Log-transformed median concentrations of ${ }^{137} \mathrm{Cs}$ by study area were regressed by year. ANOVA of the regression models were insignificant for all locations indicating very little change in 
Table 4.9. Summary of Regression Analysis and ANOVA of Log Median (LM) ${ }^{137}$ Cs in Soil

\begin{tabular}{|c|c|c|c|c|c|}
\hline \multirow[b]{2}{*}{ Area } & \multirow[b]{2}{*}{ Equation } & \multirow[b]{2}{*}{$\mathrm{R}^{2}$} & \\
\hline & & & $\underline{\mathrm{DF}}$ & F-Value & P-Value \\
\hline ffsite & $\mathrm{LM}=-1.291+0.0099 *$ Year & 0.0717 & 10 & 0.6951 & 0.4260 \\
\hline 100 Areas & $\mathrm{LM}=1.201-0.0150 *$ Year & 0.2072 & 8 & 2.4539 & 0.1612 \\
\hline 200 Areas & $\mathrm{LM}=-3.479+0.0375 *$ Year & 0.1784 & 7 & 1.3027 & 0.2972 \\
\hline 300 Area & $\mathrm{LM}=2.068-0.0256 *$ Year & 0.2603 & 7 & 2.1113 & 0.1964 \\
\hline 600 Area & $\mathrm{LM}=0.964-0.0157 *$ Year & 0.0470 & 8 & 0.3450 & 0.5754 \\
\hline
\end{tabular}

${ }^{137} \mathrm{Cs}$ concentrations over the study period (Table 4.9 and Figure 4.8 ). The persistence of ${ }^{137} \mathrm{Cs}$ in soil samples is indicative of ${ }^{137} \mathrm{Cs}$ affinity for strong sorption to clay and soil particles as indicated by the relatively high $K_{d}$ values (see Table 2.2 ). Price $(1991)$ demonstrated that ${ }^{137} \mathrm{Cs}$ was essentially retained in the top $5 \mathrm{~cm}$ of the soil column (i.e., $>98 \%$ of the soil column inventory) and has little propensity for downward movement.

\subsubsection{Vegetation}

Vegetation samples were collected for gamma spectral analysis from 1983 through 1993. During this time, the individual results ranged from $-0.026( \pm 0.03)$ to $1.9( \pm 0.06) \mathrm{pCi} / \mathrm{g}{ }^{137} \mathrm{Cs}$. About $25 \%$ of the vegetation samples collected had an associated counting error of $50 \%$ or less, the remaining samples were either negative (about 10\%) or had an associated counting error of greater than $50 \%$ (60\% of the samples). The maximum concentration for the study period was reported from the Hanford Site perimeter in 1986 and may have been influenced by the Chernobyl accident.

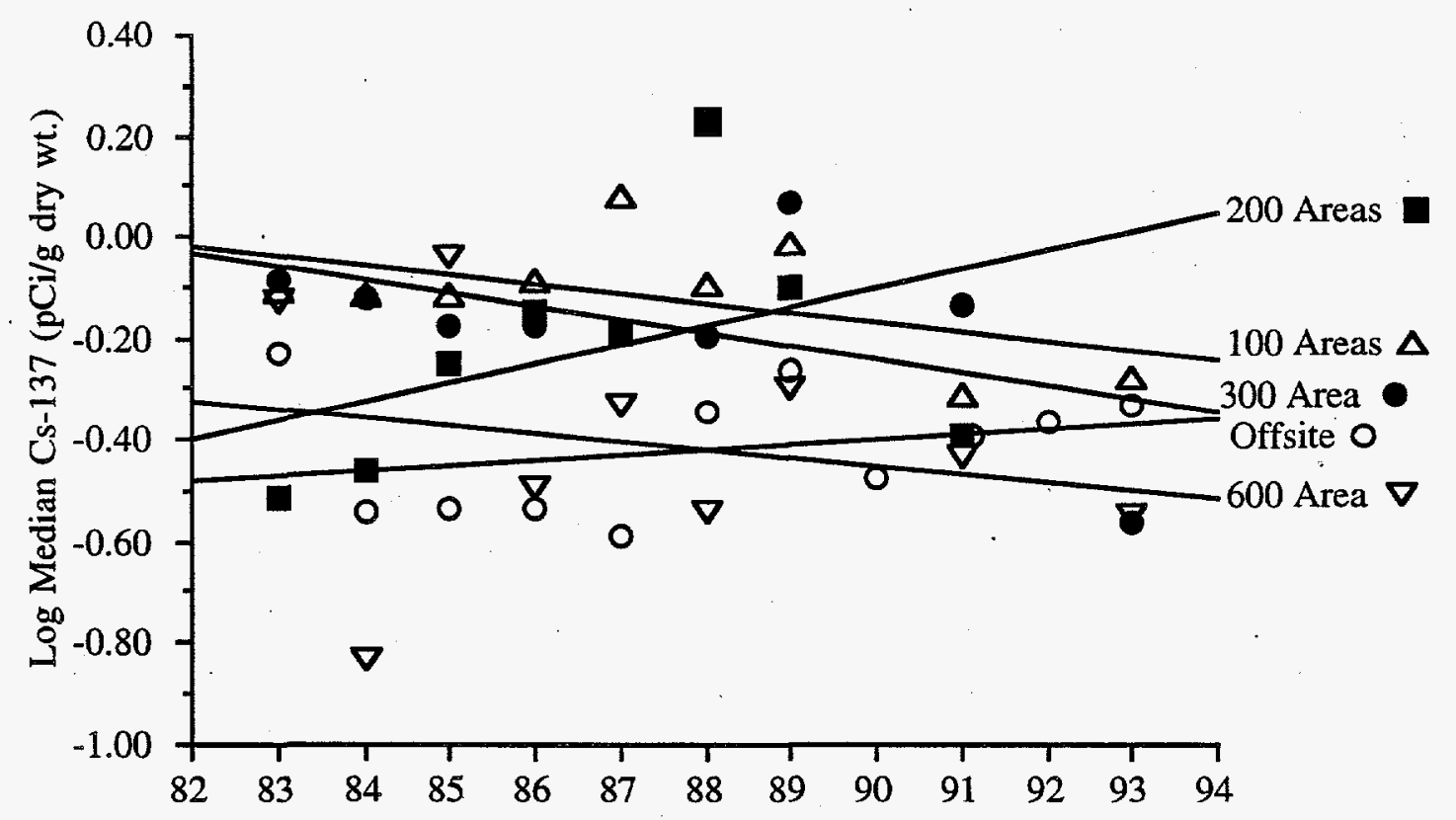

Figure 4.8. Regression Analysis of ${ }^{137} \mathrm{Cs}$ in Soil by Study Area 


\subsubsection{Spacial Differences}

A large number of ${ }^{137} \mathrm{Cs}$ concentrations in vegetation were at or below the limit of detection (MDC $=0.02 \mathrm{pCi} / \mathrm{g}$ dry weight). Based on median concentrations, the relative ranking of areas was 200 Areas $>100$ Areas $=$ offsite $=300$ Area $=600$ Area $($ Table 4.10).

The ${ }^{137} \mathrm{Cs}$ data were log-transformed $(\mathrm{pCi} / \mathrm{g}+0.03)$ and an ANOVA performed to evaluate area differences was significant (Table C.9; $\mathrm{P}=0.0001$ ). The log-transformed data were subjected to Scheffés F-test to distinguish any pair-wise differences between study areas (Table C.10).

Statistically significant differences were found between the 100 Areas and the 200 Areas $(P=0.022)$; the 200 Areas and the 600 Area $(P=0.0007)$; and the 200 Areas and offsite $(P=0.022)$.

\subsubsection{Trends}

No trend analyses were performed on the ${ }^{137} \mathrm{Cs}$ vegetation data because only about $25 \%$ of the samples had measurable concentrations at or exceeding the MDC of $0.02 \mathrm{pCi} / \mathrm{g}$. The distribution of results by year and study area as indicated by box plots (Figure C.7) indicated little change over the study period. The Chernobyl accident in 1986 may have influenced the $1986{ }^{137} \mathrm{Cs}$ measurements (Figure 4.9).

\subsection{Uranium}

Uranium has been measured by several methods in soil and vegetation samples as well as being the focal point of several special studies (Price and Kinneson 1982; Poston 1990; Tiller and Poston 1992). While several isotopes of $U$ were monitored, the focus of the evaluation of monitoring data will be on ${ }^{238} \mathrm{U}$. Annual estimated releases of ${ }^{234} \mathrm{U},{ }^{235} \mathrm{U},{ }^{236} \mathrm{U},{ }^{238} \mathrm{U}$, and Total $\mathrm{U}$ as measured by fluorometry indicate that most releases occurred in the 200 and 300 Areas (Figures A.4, A.5, A.6, A.7, and A.8).

Table 4.10. Descriptive Statistics for ${ }^{137} \mathrm{Cs}(\mathrm{pCi} / \mathrm{g})$ in Vegetation (1983 Through 1993)

\begin{tabular}{|c|c|c|c|c|c|}
\hline & 100 Areas & 200 Areas & 300 Area & 600 Area & Offsite \\
\hline Median & 0.014 & 0.048 & 0.012 & 0.011 & 0.014 \\
\hline Mean & 0.023 & 0.074 & 0.033 & 0.031 & 0.104 \\
\hline Standard Error & 0.008 & 0.011 & 0.017 & 0.016 & 0.028 \\
\hline Standard Deviation & 0.042 & 0.081 & 0.071 & 0.112 & 0.334 \\
\hline Variance & 0.002 & 0.007 & 0.005 & 0.013 & 0.111 \\
\hline Minimum & -0.010 & -0.005 & 0.003 & -0.026 & -0.013 \\
\hline Maximum & 0.209 & 0.355 & 0.314 & 0.811 & 1.900 \\
\hline Count & 29 & 58 & 18 & 52 & 139 \\
\hline
\end{tabular}




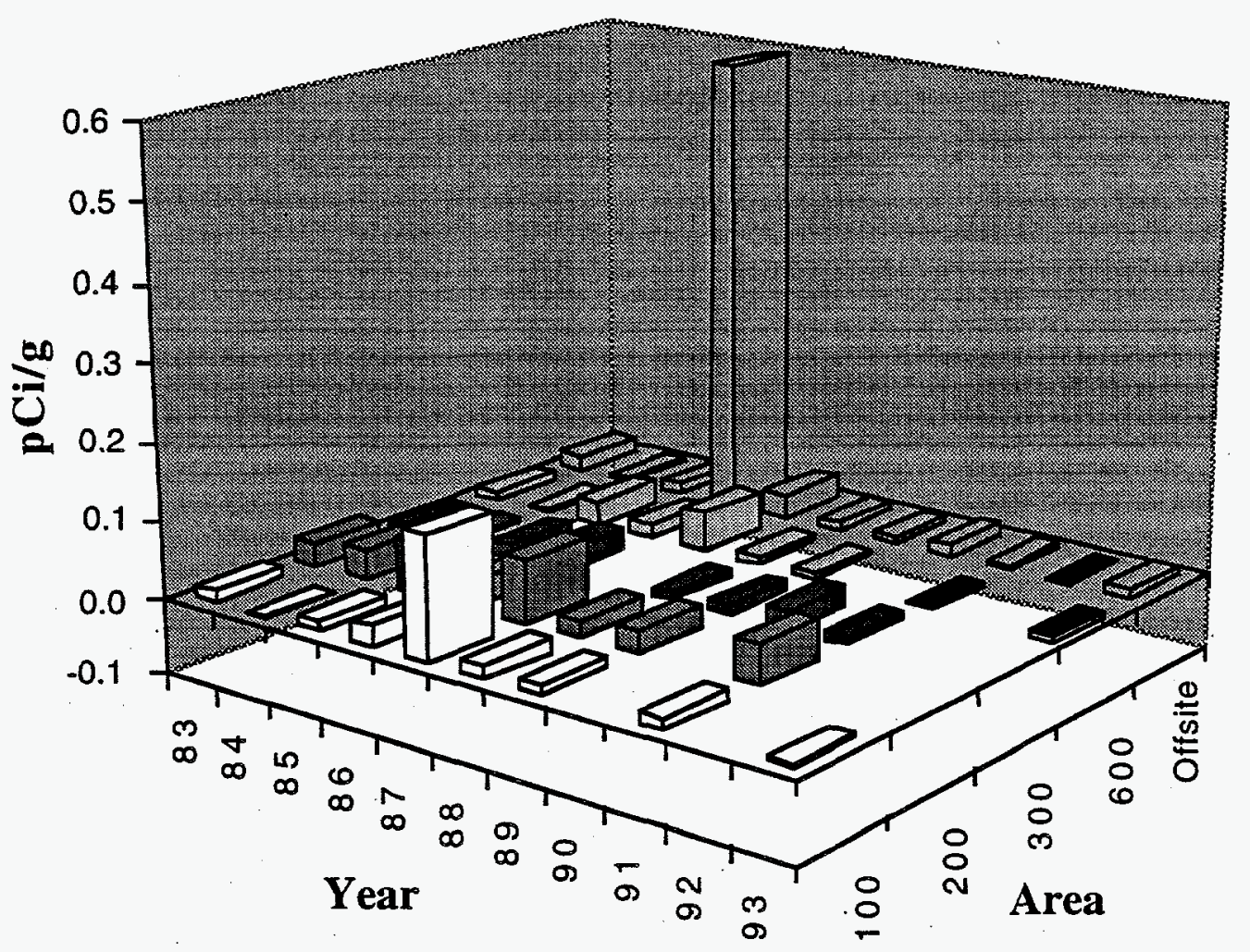

Figure 4.9. Annual Median Concentrations of ${ }^{137} \mathrm{Cs}$ in Vegetation by Study Area. Black tops on histograms indicate a negative median; spaces where boxes are missing indicate less than two locations sampled.

\subsubsection{Soil}

Evaluation of $U$ trends and study area differences was hampered by the number of analytical methods used to determined U concentrations in soil. From 1983 through 1987, a fluorometry of an acid extract was used that expressed the result as pCi/g total U (Figure 4.10). Also in 1987, a gamma spectrometry system (LEPS) was tested and used for the period of 1987 through 1989 and 1992 through 1993 (Figure 4.11). The LEPS method provided concentrations for ${ }^{235} \mathrm{U}$ and ${ }^{238} \mathrm{U}$ only. Samples collected from 1990 through 1992 were analyzed by acid extraction and dissolusion followed by alpha spectrometry of the electrodeposited residue on a stainless steel planchet. Results included ${ }^{234} \mathrm{U},{ }^{235} \mathrm{U}$, and ${ }^{238} \mathrm{U}$ (Figure 4.12). In recent years, some samples were analyzed by high resolution mass spectroscopy which provided direct measurement of isotopic ratios of ${ }^{234} \mathrm{U},{ }^{235} \mathrm{U}$, ${ }^{236} \mathrm{U}$, and ${ }^{238} \mathrm{U}$. Generally, the precision of other methods are inadequate to provide precise estimates for evaluating isotopic ratios in soil or vegetation samples. 


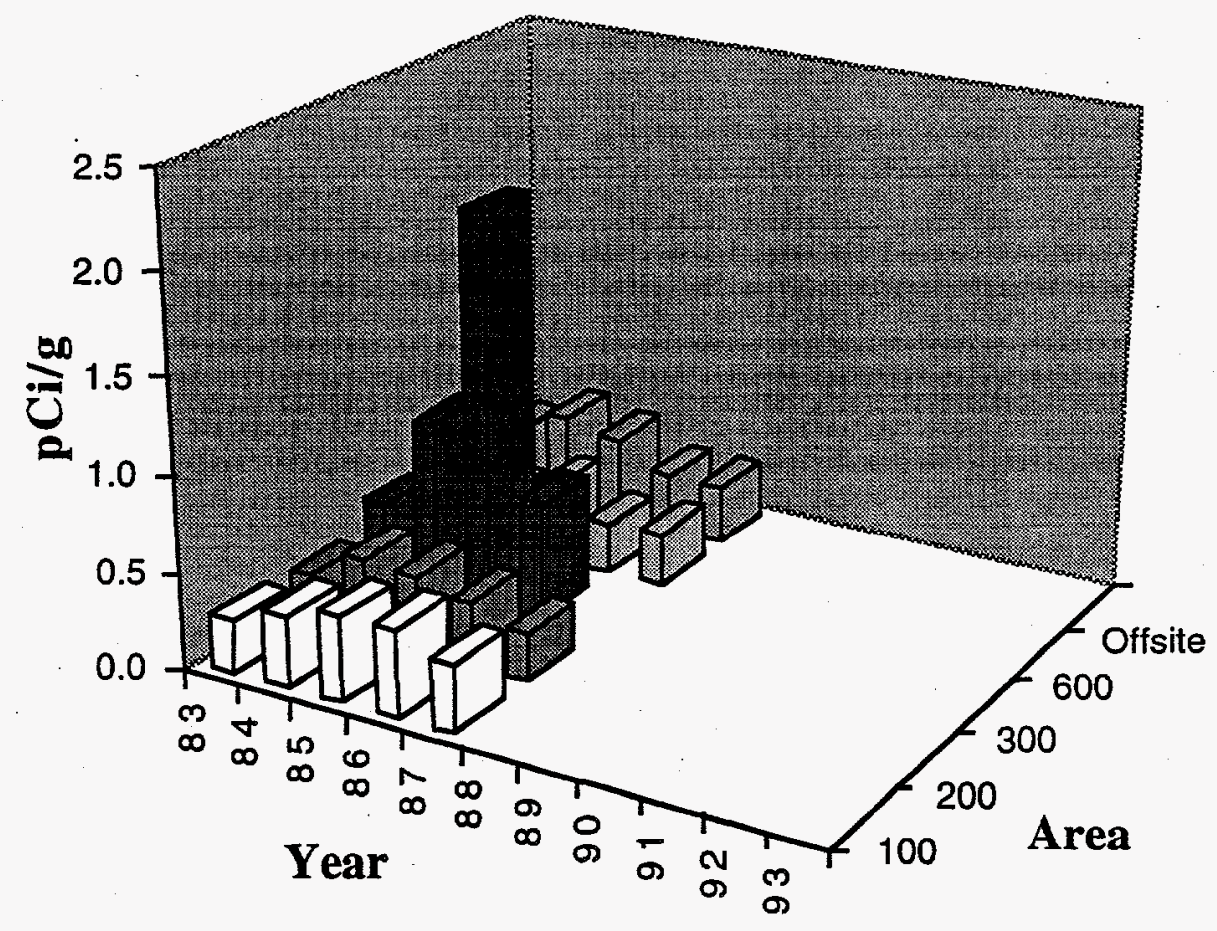

Figure 4.10. Annual Median Concentrations of $U$ in Soil (Fluorometric Analysis) by Study Area. Spaces where boxes are missing indicate less than two locations sampled.

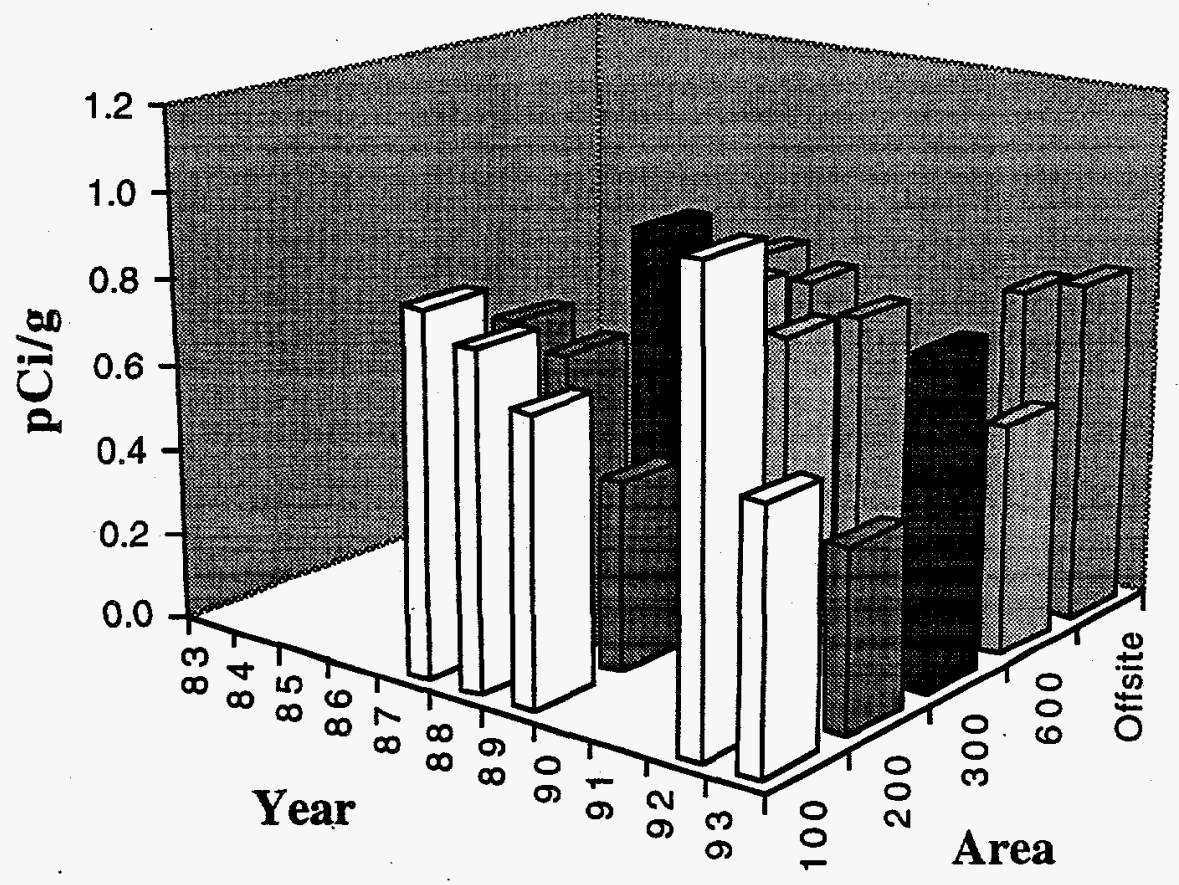

Figure 4.11. Annual Median Concentrations of ${ }^{238} \mathrm{U}$ in Soil (LEPS) by Study Area. Spaces where boxes are missing indicate less than two locations sampled. 


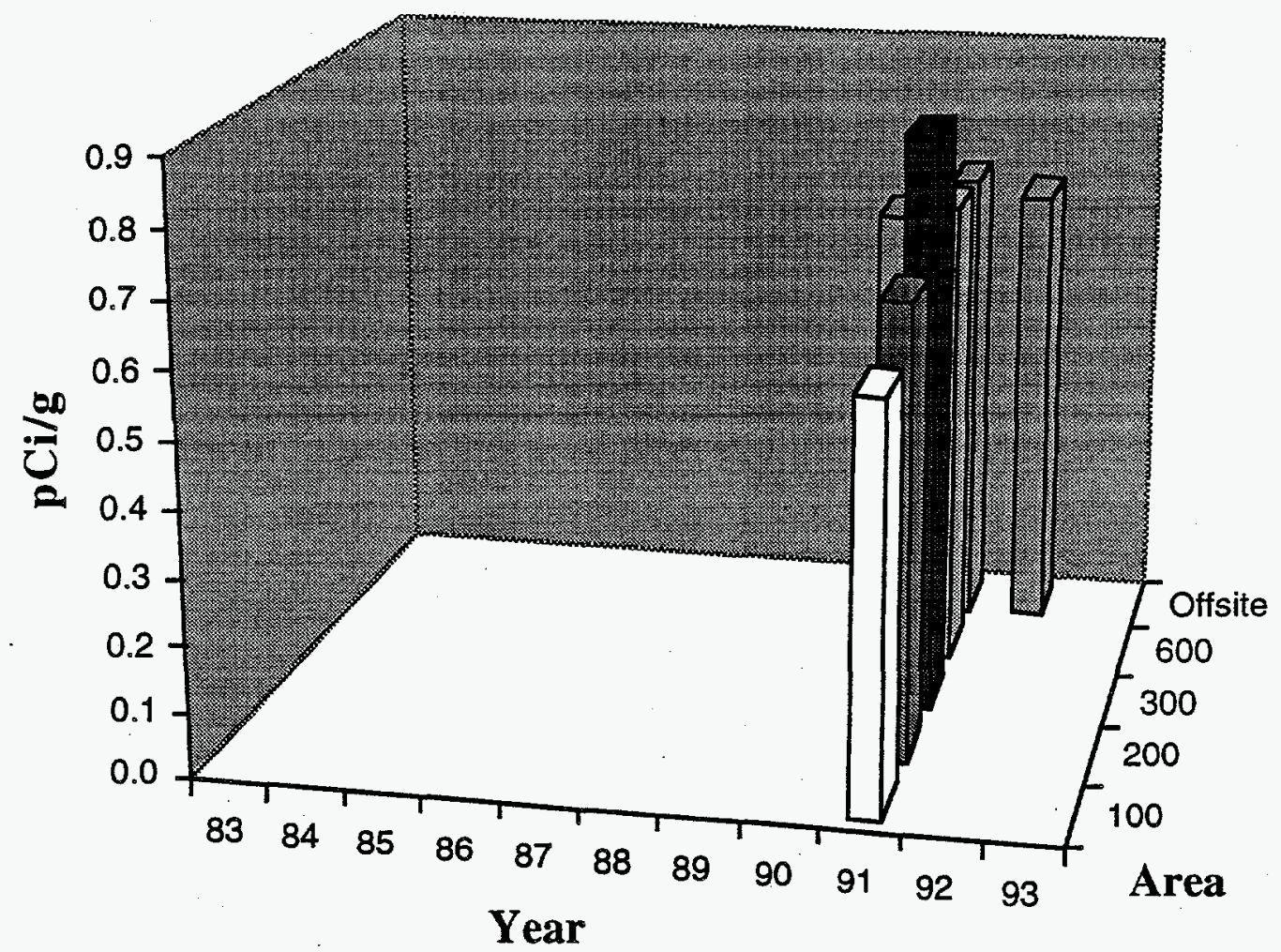

Figure 4.12. Annual Median Concentrations of ${ }^{238} \mathrm{U}$ in Soil (Alpha Spectroscopy) by Study Area. Spaces where boxes are missing indicate less than two locations sampled.

\subsubsection{Spacial Differences}

Inspection of soil results for $\mathrm{U}$ as indicated by fluorometric analysis, alpha spectroscopy and LEPS analysis indicated that the 300 Area was distinctly elevated when compared to the remaining study areas (Tables 4.11, 4.12, and 4.13). Variance estimates for the 300 Area were also the highest by two orders of magnitude. Collectively, the relative grouping by study areas was 300 Area $>100$ Areas $=200$ Areas $=600$ Area $=$ offsite.

Table 4.11. Descriptive Statistics for U (pCi/g by Fluorometric Analysis) in Soil (1983 Through 1987)

\begin{tabular}{|c|c|c|c|c|c|}
\hline & 100 Areas & 200 Areas & 300 Area & 600 Area & $\underline{\text { Offsite }}$ \\
\hline Median & 0.390 & 0.335 & 0.710 & 0.278 & 0.370 \\
\hline Mean & 0.368 & 0.367 & 1.579 & 0.325 & 0.422 \\
\hline Standard Error & 0.026 & 0.026 & 0.544 & 0.023 & 0.027 \\
\hline Standard Deviation & 0.099 & 0.153 & 1.721 & $0: 131$ & 0.240 \\
\hline Variance & 0.010 & 0.023 & 2.963 & 0.017 & 0.057 \\
\hline Minimum & 0.191 & 0.177 & 0.310 & 0.162 & 0.082 \\
\hline Maximum & 0.529 & 1.030 & 5.440 & 0.798 & 1.250 \\
\hline Count & 15 & 35 & 10 & 33 & 77 \\
\hline
\end{tabular}


Table 4.12. Descriptive Statistics for ${ }^{238} \mathrm{U}$ (pCi/g by Alpha Spectroscopy) in Soil (1991 Through 1992)

\begin{tabular}{|c|c|c|c|c|c|}
\hline & 100 Areas & 200 Areas & 300 Areà & 600 Area & Offsite \\
\hline Median & 0.610 & 0.687 & 0.867 & 0.711 & 0.658 \\
\hline Mean & 0.613 & 0.726 & 0.867 & 0.707 & 0.671 \\
\hline Standard Error & 0.038 & 0.049 & 0.153 & 0.055 & 0.026 \\
\hline Standard Deviation & 0.076 & 0.138 & 0.216 & 0.122 & 0.129 \\
\hline Variance & 0.006 & 0.019 & 0.047 & 0.015 & 0.017 \\
\hline Minimum & 0.545 & 0.535 & 0.714 & 0.577 & 0.460 \\
\hline Maximum & 0.687 & 0.957 & 1.020 & 0.887 & 0.905 \\
\hline Count & 4 & 8 & 2 & 5 & 25 \\
\hline
\end{tabular}

Table 4.13. Descriptive Statistics for ${ }^{238} \mathrm{U}$ (pCi/g by LEPS Analysis) in Soil (1987 Through 1989 and 1992 and 1993)

\begin{tabular}{|c|c|c|c|c|c|}
\hline & 100 Areas & 200 Areas & 300 Area & 600 Area & Offsite \\
\hline Median & 0.7 & 0.6 & 0.9 & 0.7 & 0.7 \\
\hline Mean & 0.8 & 0.7 & 1.2 & 0.7 & 0.7 \\
\hline Standard Error & 0.1 & 0.0 & 0.4 & 0.0 & 0.0 \\
\hline Standard Deviation & 0.3 & 0.3 & 1.0 & 0.3 & 0.3 \\
\hline Variance & 0.1 & 0.1 & 0.9 & 0.1 & 0.1 \\
\hline Minimum & 0.4 & 0.4 & 0.3 & 0.3 & 0.1 \\
\hline Maximum & 1.5 & 1.2 & 3.3 & 1.5 & 1.8 \\
\hline Count & 18 & 28 & 7 & 30 & 79 \\
\hline
\end{tabular}

When segregated by isotope and analytical methods, the only $U$ isotope with significantly different concentrations among study areas was total $\mathrm{U}$ by fluorometry from 1983 through 1987 (P < 0.0001 ; Table C.11). Other statistical analyses of $238 \mathrm{U}$ by LEPS and alpha spectroscopy were not significant $(\mathrm{P}>0.05$; Tables C.13 and C.14, respectively). Scheffé's post hoc test indicated that $U$ was significantly higher in the 300 Area than all other study areas for samples analyzed by fluorometry(P $<0.0001$ for all comparisons, Table C.12). Caution is needed when comparing $U$ results obtained by different methods. The LEPS method will measure all the ${ }^{238} \mathrm{U}$ and ${ }^{235} \mathrm{U}$ in a sample. The fluormetric method and alpha spectrometry methods will measure those isotopes of $U$ that are dissolved and extracted, hence there is a potential for a low bias depending on the completeness of the extraction process.

The 300 Area was the focus of several special $U$ investigations, primarily because the area contained facilities that manufactured nuclear fuel. Studies of U along the Franklin County shore of the Columbia River (east and north of the 300 Area) indicated a naturally elevated level of $U$ (analyzed by fluorometry) compared to samples collected onsite and in other remote "control" areas (Price and Kinneson 1982). Interest in the study area was prompted by concerns that wind patterns would disperse contaminated dust or atmospheric effluents from the 300 Area onto private land east of the Hanford Site. Examination of soil samples from downwind locations indicated that ratios of ${ }^{235} U$ to ${ }^{238} U$ were comparable to control areas and there was no indication of $U$ contamination from the 300 Area. Processed $U$ from the 300 Area has an enrichment of 0.977 atom percent ${ }^{235} \mathrm{U}$ (ERDA 1975) compared to 0.71 atom percent ${ }^{235} U$ in un-enriched $U$ (Seaborg 1973). 
Since the completion of the 1982 study (Price and Kinneson 1982), refinements in high resolution mass spectrometry have allowed for the identification of ${ }^{236} \mathrm{U}$. Uranium- 236 is an activation product of ${ }^{235} \mathrm{U}$ and is associated with spent and processed nuclear fuel. Consequently, it was present in the industrial effluents associated with fuel processing in the 300 Area and has been identified as an indicator of dispersal of $U$ from the 300 Area. Releases of $236 \mathrm{U}$ have been documented for the 200 Areas (Figure A.6); however, most of the releases in the 300 Area occurred prior to the implementation of monitoring for this isotope. Uranium-236 was found in eight soil samples collected in an area immediately north and slightly downwind of the 300 Area in 1989 (Poston 1990). The results were reported as ratios of ${ }^{236} \mathrm{U}:{ }^{238} \mathrm{U}$ on a gram-atom basis from high resolution mass spectrometry. Isotopic ratios were highest in samples collected closest to the 300 Area and decreased at more distant locations.

On August 20,1992, five replicate soil samples were collected from PNL's Sagemoor soil and natural vegetation sampling location to look for ${ }^{236} \mathrm{U}$. The presence of $236 \mathrm{U}$ in Sagemoor soils would indicate that past fuel processing activities in the 300 Area (west and generally upwind of the Sagemoor soil sampling location) have resulted in atmospheric deposition of $U$ at this site. Mass spectroscopy results were reported as the atom percentage (Table 4.14). Atoms/sample for ${ }^{236} \mathrm{U}$ were 13 to 24 times greater than the ITAS sample preparation process blank indicating the presence of ${ }^{236} \mathrm{U}$ in Sagemoor soil samples. The amount present $\left(4.4 \times 10^{9}\right.$ to $7.9 \times 10^{9}$ atoms $)$ is minute and cannot be accurately expressed on a gravimetric scale due to the extremely small aliquot of sample extract analyzed on the mass spectrometer. Isotopic ratios of ${ }^{234} \mathrm{U}:{ }^{238} \mathrm{U}$ and ${ }^{235} \mathrm{U}:{ }^{238} \mathrm{U}$ were within expected ranges. The mean ratio of ${ }^{236} \mathrm{U}:{ }^{238} \mathrm{U}$ was $1.34 \times 10^{-6}(\mathrm{n}=5)$. The estimated amount of ${ }^{236} \mathrm{U}$ based on a mean concentration of $0.706 \mathrm{pCi}{ }^{238} \mathrm{U} / \mathrm{g}$ of soil was $1.0 \times 10^{-10} \mathrm{pCi} / \mathrm{g}$ in Sagemoor soils. (a)

This estimate does not account for the background of the process blank. Ratios of ${ }^{236} \mathrm{U}:{ }^{238} \mathrm{U}$ in soil samples collected on the Hanford Site north of the 300 Area in 1989 ranged from $1.4 \times 10^{-6}$ to $3.22 \times 10^{-6} \mathrm{in}$ the more distant northerly locations (more than $1.4 \mathrm{~km}$ north of the 300 Area perimeter); however, sample sites close to the 300 Area (between 1.1 to $1.3 \mathrm{~km}$ north of the northern perimeter of the 300 Area) had distinctly higher ratios $\left(9.17 \times 10^{-6}\right.$ to $\left.1.9 \times 10^{-5}\right)$. The amount of ${ }^{236} \mathrm{U}$ (if any) that may be present in soils from atmospheric testing of nuclear weapons is unknown.

Table 4.14. Atom Percentage of U Isotpes in Sagemoor Soils, 1992 Samples

Atom Percent ( \pm 2 Sigma Error)

\begin{tabular}{|c|c|c|c|}
\hline${ }^{234} \mathrm{U}$ & ${ }^{235} \mathrm{U}$ & $236 \mathrm{U}$ & ${ }^{238} \mathrm{U}$ \\
\hline $0.00549 \pm 0.00014$ & $0.718 \pm 0.002$ & $0.000164 \pm 0.000016$ & $99.276 \pm 0.002$ \\
\hline $0.00549 \pm 0.00006$ & $0.720 \pm 0.002$ & $0.000177 \pm 0.000012$ & $99.275 \pm 0.002$ \\
\hline $0.00541 \pm 0.00008$ & $0.716 \pm 0.006$ & $0.000098 \pm 0.000008$ & $99.278 \pm 0.006$ \\
\hline $0.00552 \pm 0.00006$ & $0.721 \pm 0.004$ & $0.000102 \pm 0.000010$ & $99.273 \pm 0.004$ \\
\hline $0.00547 \pm 0.00008$ & $0.719 \pm 0.006$ & $0.000125 \pm 0.000014$ & $99.276 \pm 0.006$ \\
\hline \multicolumn{4}{|c|}{ Expected Atom Percent (Friedlander et al. 1964) } \\
\hline 0.0056 & 0.7205 & 0.0000 & 99.272 \\
\hline
\end{tabular}

$\overline{\text { (a) } \quad \mathrm{pCi}}{ }^{236} \mathrm{U} / \mathrm{g}$ soil $=7.06 \times 10^{-1} \mathrm{pCi}{ }^{238} \mathrm{U} \times\left[1.124 \times 10^{2} \mathrm{pmole}^{238} \mathrm{U} / \mathrm{pCi}{ }^{238} \mathrm{U}\right] \times\left[1.34 \times 10^{-6}\right.$ pmole $\left.{ }^{236} \mathrm{U} / \mathrm{pmole}{ }^{238} \mathrm{U}\right] \times\left[9.42 \times 10^{-7} \mathrm{pCi}{ }^{236} \mathrm{U} / \mathrm{pmole}{ }^{236} \mathrm{U}\right]$. 
These observations indicate some past dissemination of $U$ in areas downwind (generally east and north) and adjacent to the 300 Area; however, the amount released was very small and is apparently indistinguishable from natural levels of $U$ unless very sensitive high resolution analytical methods are used.

\subsubsection{Trends}

Uranium ${ }^{234} \mathrm{U},{ }^{235} \mathrm{U}$, and ${ }^{238} \mathrm{U}$ have very long half-lives and radiological decay would not significantly decrease concentrations over the period covered in this report. As indicated earlier, the evaluation of trends and area differences was confounded by the three different methods used for analysis of $\mathrm{U}$. Trends for ${ }^{238} \mathrm{U}$ measured by flourometry are presented separately for the period 1983 through 1987 (Figure 4.10), and from 1987 through 1993 (Figures 4.11 and 4.12) because of the other methods used. No trends were apparent in the median concentrations as depicted in box plots (Figure C.8 and C.9). These figures indicated no change over time with the exception of elevated measurements around the 300 Area from 1984 through 1987. Recent measurements from the 300 Area fall within the range of other onsite areas and offsite measurements. Overall, there has been no consistent decrease or increase of $U$ in soils on or off the Hanford Site.

\subsubsection{Vegetation}

Vegetation samples were analyzed by two methods: fliorometric analysis of ash residue (1983 through 1992), and alpha spectroscopy of ash residue (1991 through 1993). The fluorometric analysis provided a measurement of total $U$ in vegetation. Alpha spectroscopy results for ${ }^{234} \mathrm{U},{ }^{235} \mathrm{U}$, and ${ }^{238} \mathrm{U}$ were predominantly below detection. This method did not detect ${ }^{234} \mathrm{U}$ and ${ }^{235} \mathrm{U}$ in dried vegetation.

\subsubsection{Spacial Differences}

Elevated concentrations of $U$ were noted in 1985 and again in 1990 in vegetation (Figure 4.13). Generally, there was a tendency for elevated concentrations to be associated with samples from the 300 Area and offsite locations (Table 4.15). The offsite locations were heavily influenced by elevated values in samples collected in 1990; however, these results may have been affected by extended archiving prior to analysis or an uncontrolled bias during analysis. ANOVA of the $\log$ transformed data ( $\mathrm{pCi} / \mathrm{g}+0.00896)$ was significant for differences between study areas (Table C.15); however, Scheffé's correction for multiple comparisons did not reveal any significant differences between areas (Table C.16). Consequently, apparent differences in $U$ in vegetation by area were considered marginal and random.

\subsubsection{Trends}

There was no apparent trend in the vegetation data over the study period as indicated by the box plots of the fluorometric analytical data (Figure C.10). Additional statistical analyses have not been performed. 


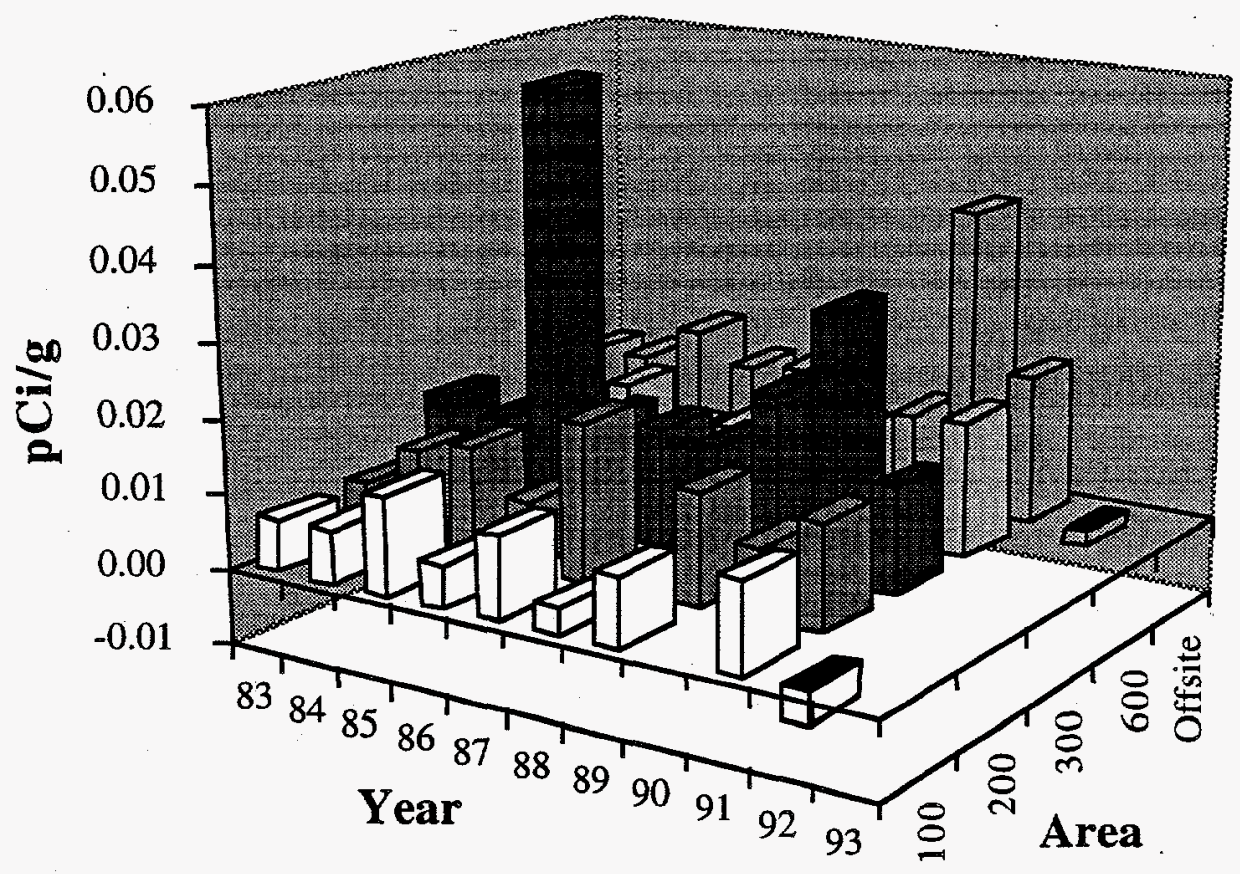

Figure 4.13. Annual Median Concentrations of Total U in Vegetation (Fluorometric Analysis) by Study Area. Black tops on histograms indicate a negative median; spaces where boxes are missing indicate less than two locations sampled.

\subsection{Plutonium}

Plutonium was measured by alpha spectroscopy and results were obtained for ${ }^{238} \mathrm{Pu}$ and $239,240 \mathrm{Pu}$. Concentrations of $239,240 \mathrm{Pu}$ were consistently detected in soil; however, Pu isotopes were only marginally detected in vegetation. On a dry weight basis, concentrations in soil exceeded concentrations in vegetation by two orders of magnitude. Annual releases of ${ }^{238} \mathrm{Pu}$ and ${ }^{239,240} \mathrm{Pu}$ were greatest in the 200 Areas (Figures A.9 and A.10). The MDCs for ${ }^{238} \mathrm{Pu}$ and ${ }^{239,240} \mathrm{Pu}$ were $0.0006 \mathrm{pCi} / \mathrm{g}$.

Table 4.15. Descriptive Statistics for U (pCi/g by Fluorometric Analysis) in Vegetation (1983 Through 1993)

\begin{tabular}{|c|c|c|c|c|c|}
\hline & 100 Areas & 200 Areas & 300 Area & 600 Area & Offsite \\
\hline Median & 0.007 & 0.011 & 0.018 & 0.009 & 0.015 \\
\hline Mean & 0.008 & 0.013 & 0.023 & 0.010 & 0.031 \\
\hline Standard Error & 0.001 & 0.001 & 0.004 & 0.001 & 0.006 \\
\hline Standard Deviation & 0.006 & 0.011 & 0.018 & 0.006 & 0.064 \\
\hline Variance $^{(a)}$ & 0.000 & 0.000 & 0.000 & 0.000 & 0.004 \\
\hline Minimum & -0.004 & -0.001 & 0.009 & 0.000 & -0.010 \\
\hline Maximum & 0.025 & 0.070 & 0.082 & 0.026 & 0.470 \\
\hline Count & 24 & 56 & 17 & 48 & 120 \\
\hline
\end{tabular}

(a) Values $=0.000$ indicate variance estimates were $<0.0005$ 


\subsubsection{Soil}

Plutonium was measured as ${ }^{238} \mathrm{Pu}$ and as $239,240 \mathrm{Pu}$ by dissolution of the soil matrix, separation of $\mathrm{Pu}$, and alpha spectrometry of the residue. Data were collected consistently over the study period. There were few changes in ${ }^{238} \mathrm{Pu}$ and ${ }^{239,240} \mathrm{Pu}$ concentrations over the study period (Figures 4.14 and 4.15).

\subsubsection{Spacial Differences}

Evaluation of ${ }^{238} \mathrm{Pu}$ soil data indicate that the 200 Areas have higher mean, median, and maximum concentrations than the other study areas (Table 4.16). The general distribution pattern for ${ }^{238} \mathrm{Pu}$ concentrations was 200 Areas $>100$ Areas $=300$ Area $>$ offsite $=600$ Area; however, all study area medians were below the MDC.

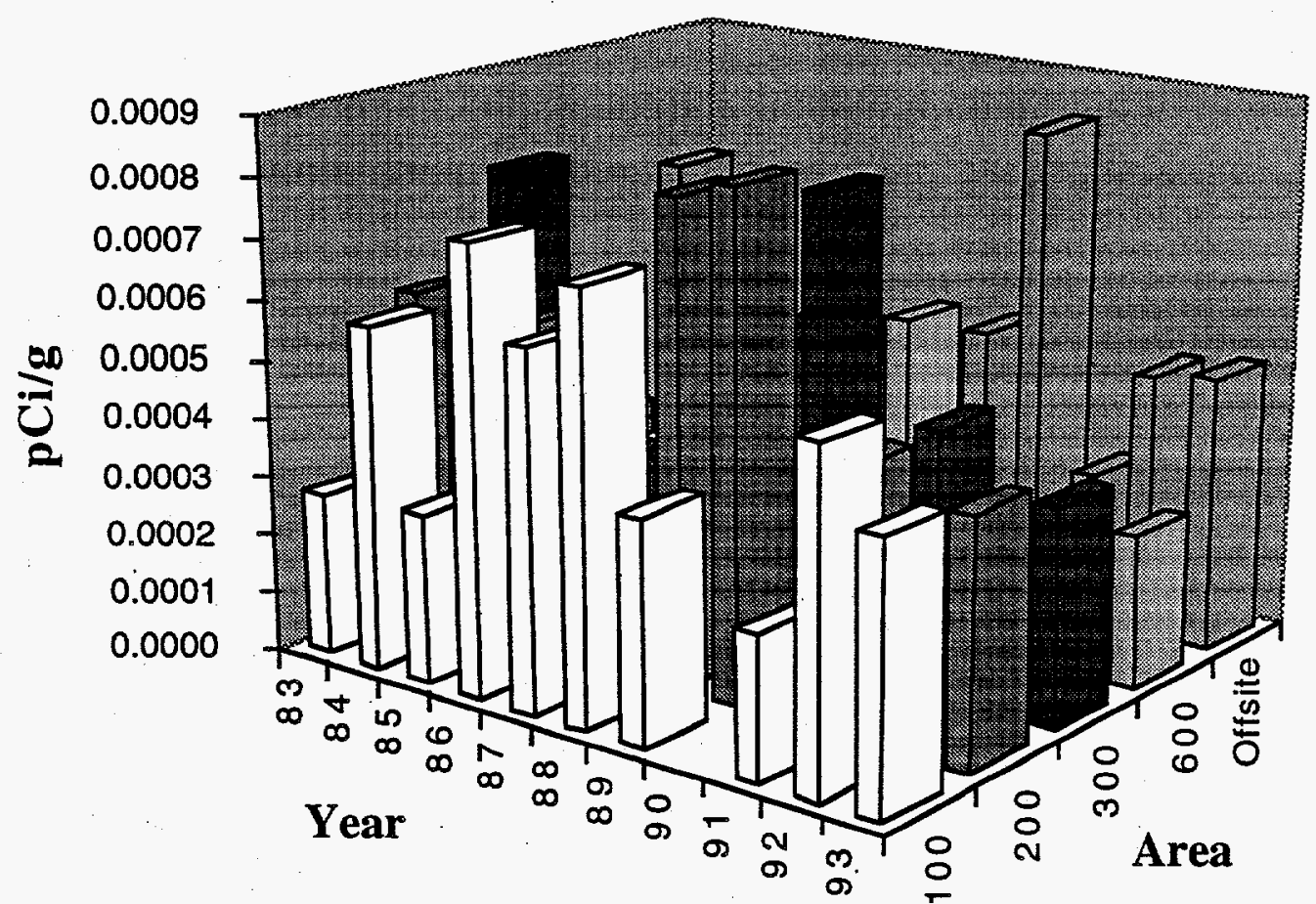

Figure 4.14. Annual Median Concentrations of ${ }^{238} \mathrm{Pu}$ in Soil by Study Area. Spaces where boxes are missing indicate less than two locations sampled. 


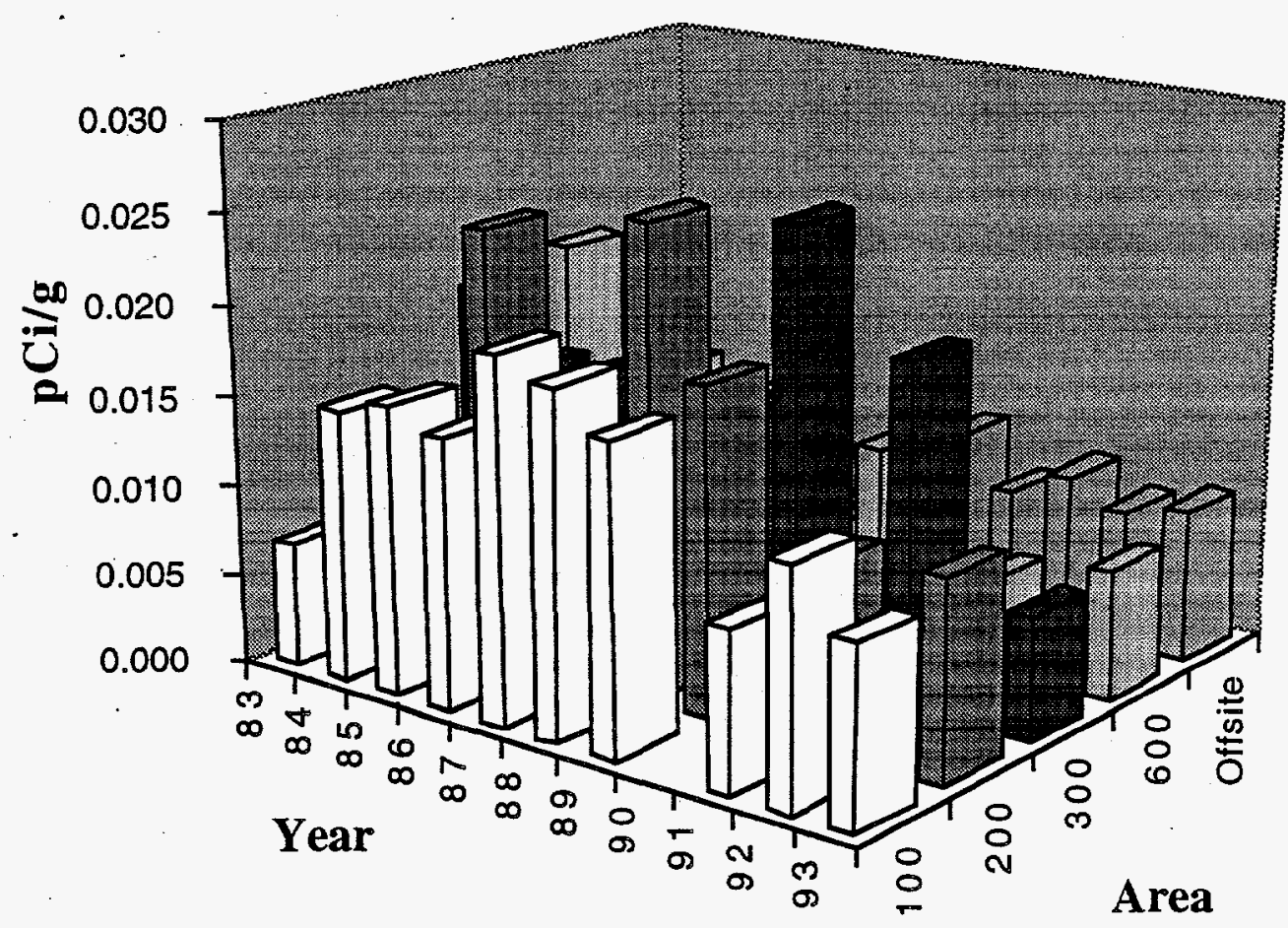

Figure 4.15. Annual Median Concentrations of $239,240 \mathrm{Pu}$ in Soil by Study Area. Spaces where boxes are missing indicate less than two locations sampled.

Table 4.16. Descriptive Statistics for ${ }^{238} \mathrm{Pu}(\mathrm{pCi} / \mathrm{g})$ in Soil (1983 Through 1993)

\begin{tabular}{|c|c|c|c|c|c|}
\hline & 100 Areas & 200 Areas & 300 Area & 600 Area & Offsite \\
\hline Median & 0.00044 & 0.00050 & 0.00043 & 0.00027 & 0.00034 \\
\hline Mean & 0.00048 & 0.00188 & 0.00046 & 0.00046 & 0.00055 \\
\hline Standard Error & 0.00004 & 0.00065 & 0.00007 & 0.00007 & 0.00006 \\
\hline Standard Deviation & 0.00026 & 0.00524 & 0.00028 & 0.00057 & 0.00071 \\
\hline Variance $^{(a)}$ & 0.00000 & 0.00003 & 0.00000 & 0.00000 & 0.00000 \\
\hline Minimum & -0.00010 & -0.00002 & 0.00000 & -0.00007 & -0.00002 \\
\hline Maximum & 0.00120 & 0.03960 & 0.00104 & 0.00331 & 0.00616 \\
\hline Count & 35 & 65 & 17 & 62 & 154 \\
\hline
\end{tabular}

(a) Values $=0.000$ indicate variance estimates were $<0.0005$.

The distribution of $239,240 \mathrm{Pu}$ was similar to ${ }^{238} \mathrm{Pu}$. Again, there was an indication that concentrations in the 200 Areas were elevated compared to the 600 Area and offsite locations (Table 4.17). However, the relative ranking of median $239,240 \mathrm{Pu}$ concentrations was 100 Areas $=200$ Areas $=300$ Area $>600$ Area $=$ offsite. Over the 11 -year study period, concentrations of $239,240 \mathrm{Pu}$ were consistently highest at one sampling location in the 200 Areas, the East of 200-West Gate. Generally, variance estimates and the maximum and mean concentrations of $239,240 \mathrm{Pu}$ were distinctly higher in the 200 Areas compared to other areas. 
Table 4.17. Descriptive Statistics for ${ }^{239,240} \mathrm{Pu}(\mathrm{pCi} / \mathrm{g})$ in Soil (1983 Through 1993)

$\begin{array}{lccccc} & \frac{100 \text { Areas }}{0.01340} & \frac{200 \text { Areas }}{0.01400} & \frac{300 \text { Area }}{0.01460} & \frac{600 \text { Area }}{0.00803} & \text { Offsite } \\ \text { Median } & 0.01458 & 0.08687 & 0.01498 & 0.01069 & 0.00988 \\ \text { Mean } & 0.00120 & 0.02330 & 0.00154 & 0.00106 & 0.00061 \\ \text { Standard Error } & 0.00713 & 0.18783 & 0.00634 & 0.00833 & 0.00752 \\ \text { Standard Deviation } & 0.00005 & 0.03528 & 0.00004 & 0.00007 & 0.00006 \\ \text { Variance } & 0.00077 & 0.00032 & 0.00359 & 0.00068 & 0.00003 \\ \text { Minimum } & 0.02960 & 0.83100 & 0.02540 & 0.03420 & 0.03310 \\ \text { Maximum } & 35 & 65 & 17 & 62 & 154 \\ \text { Count } & & & & & \end{array}$

Subsequent ANOVA of log-transformed data indicated that the 200 Areas had slightly elevated but statistically significant concentrations of both ${ }^{238} \mathrm{Pu}$ (Table C.17) and ${ }^{239 / 240} \mathrm{Pu}$ (Table C.19). For ${ }^{238} \mathrm{Pu}$ (Table C.18), the 200 Areas had significantly elevated concentrations compared to the offsite areas $(P=0.0011)$ and the 600 Area $(P=0.0057)$. No other combinations of study area comparisons were significant. For ${ }^{239 / 240} \mathrm{Pu}$ (Table C.20), the pattern was duplicated with the 200 Areas having a log-transformed mean concentration significantly exceeding the offsite locations ( $P$ $<0.0001)$ and 600 Area $(P=0.0003)$.

\subsubsection{Trends}

Trends were evaluated by regression analysis of log-transformed median $239,240 \mathrm{Pu}$ concentrations over time for each study area (Table 4.18). None of the regression ANOVAs were significant $(P<0.05)$, nor were there any large coefficients of correlation $\left(R^{2}\right)$ over time for any of the study areas. The data analysis indicated no significant increase or decrease of $\mathrm{Pu}$ in soil over the study period (Figure 4.16).

Plutonium has a very strong propensity to sorb to soil and generally would not be dissolved by soil water. Soil microbes can affect soil transport of $\mathrm{Pu}$, primarily by the formation of soluble organic complexes (Wildung et al. 1987), however, the impact is minimal and is further diminished under arid conditions found at Hanford. The primary route of environmental transport of soil bound $\mathrm{Pu}$ is erosion transport rather than dissolution by precipitation (Foster and Hakonson 1987). Studies on soil cores have shown that $\mathrm{Pu}(>95 \%)$ was retained in the upper $5 \mathrm{~cm}$ of the soil

Table 4.18. Summary of Regression Analysis and ANOVA of Log Median (LM) $239,240 \mathrm{Pu}$ in Soil

\begin{tabular}{|c|c|c|c|c|c|}
\hline \multirow[b]{2}{*}{ Area } & \multirow[b]{2}{*}{ Equation } & \multirow[b]{2}{*}{$\mathrm{R}^{2}$} & \multicolumn{3}{|c|}{ ANOVA } \\
\hline & & & DF & F-Value & P-Value \\
\hline Offsite & $\overline{L M}=-1.6977-0.0045 *$ Year & 0.0120 & 10 & 0.1092 & 0.7486 \\
\hline 100 Areas & $\mathrm{LM}=-1.5333-0.0039 *$ Year & 0.0080 & 9 & 0.0643 & 0.8063 \\
\hline 200 Areas & $\mathrm{LM}=-2.2121+0.0375 *$ Year & 0.0432 & 8 & 0.0304 & 0.8665 \\
\hline 300 Area & $\mathrm{LM}=-0.6424-0.0138 *$ Year & 0.0844 & 8 & 0.5531 & 0.4852 \\
\hline 600 Area & $\mathrm{LM}=0.3498-0.0279 *$ Year & 0.2266 & 8 & 2.0506 & 0.1952 \\
\hline
\end{tabular}




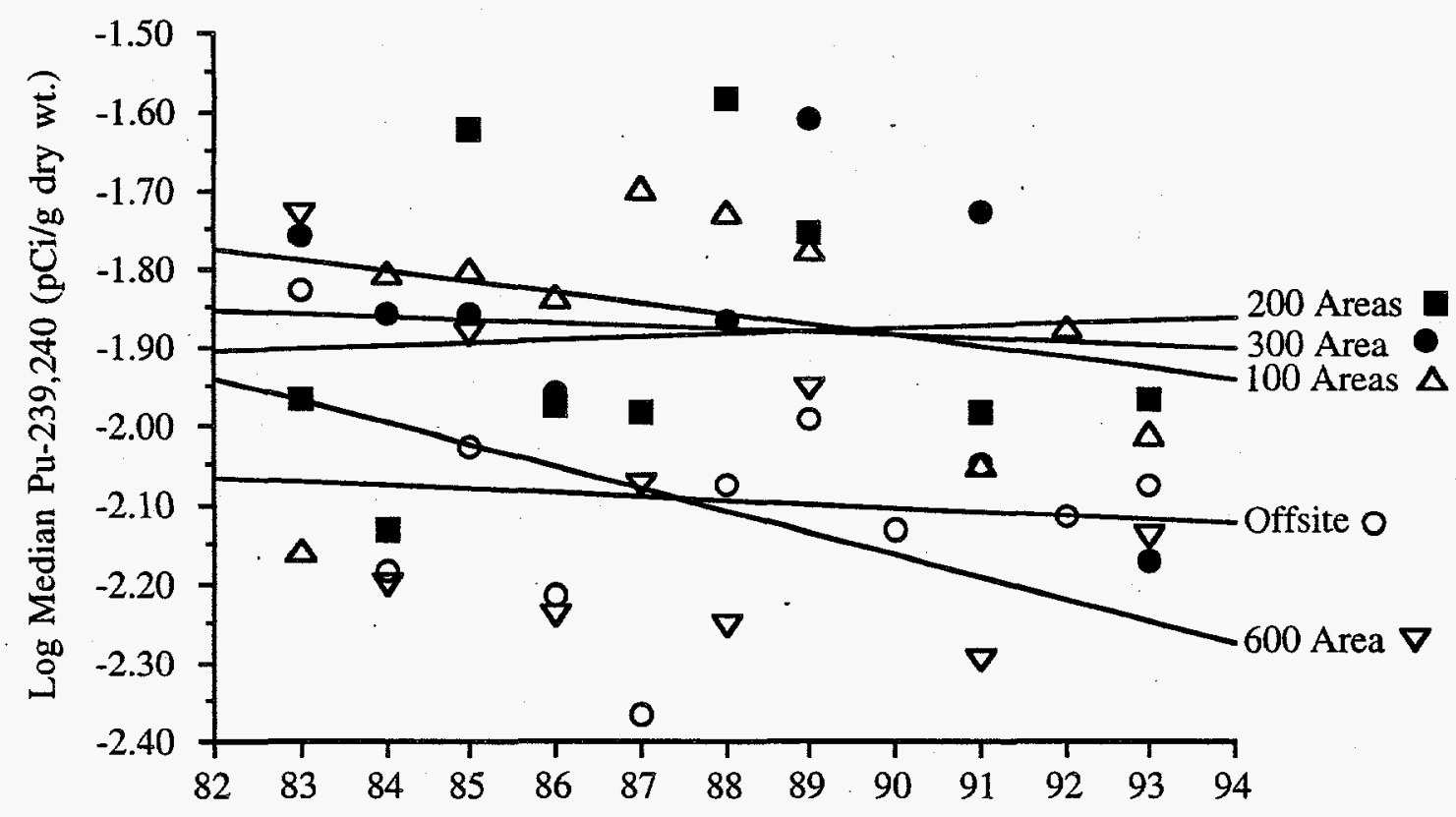

Figure 4.16. Regression Analysis of ${ }^{239,240} \mathrm{Pu}$ in Soil by Study Area

column and there was little downward migration of $\mathrm{Pu}$ in the soil column associated with precipitation (Price 1991). Stability of soil concentrations over the study period was expected as the radiological half-lives of the $\mathrm{Pu}$ isotopes are very long compared to the length of the study period.

\subsubsection{Vegetation}

Plutonium-238 and $239,240 \mathrm{Pu}$ have been analyzed by alpha spectroscopy of dried and ashed vegetation residue. Plutonium-238 was measured in three of the 281 samples analyzed over the study period. No additional evaluation of ${ }^{238} \mathrm{Pu}$ concentration in vegetation was performed. The following discussion focuses solely on ${ }^{239,240} \mathrm{Pu}$ in vegetation.

\subsubsection{Spacial Differences}

Plutonium-239,240 was frequently detected in vegetation samples collected onsite and offsite. Many of the measured concentrations were below the $0.0006 \mathrm{pCi} / \mathrm{g}$ dry weight MDC, indicating that measured concentrations were close to the limits of detection. Median concentrations exceeded the MDC during the early years of the study period (Figure 4.17). Evaluation of median $239,240 \mathrm{Pu}$ concentrations indicated that the relative rank of study areas was 200 Areas $>600$ Area $=100$ Areas $=300$ Areas $>$ offsite (Table 4.19). The East of the 200 West Gate location in the 200 Areas routinely had the highest concentrations of $239,240 \mathrm{Pu}$ in vegetation. 


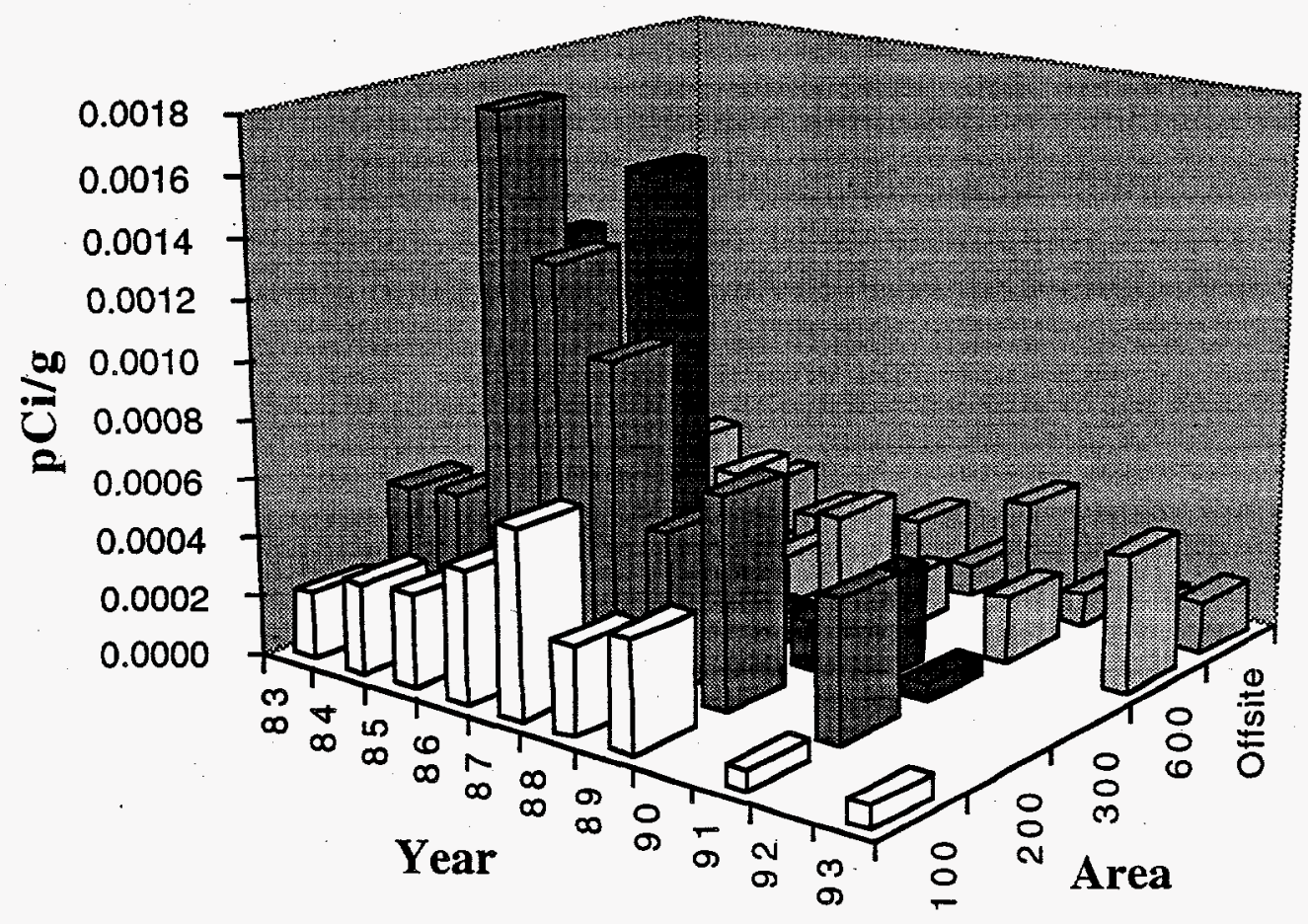

Figure 4.17. Annual Median Concentrations of $239,240 \mathrm{Pu}$ in Vegetation by Study Area. Spaces where boxes are missing indicate less than two locations sampled.

Evaluation of the data indicated that ${ }^{239,240} \mathrm{Pu}$ in vegetation, grouped by study area, was lognormally distributed. The data were log-transformed after adding 0.00015 to eliminate negative values in the data base. Further inspection of the data suggested that there was a possible low-bias in results from the 100 Areas in samples collected 1990 through 1993 . These samples were analyzed by ITAS and samples prior to 1990 were analyzed by UST. The $239,240 \mathrm{Pu}$ data were grouped by laboratory and study area for ANOVA. Analysis of variance of the transformed data grouped by area and laboratory was significant (Table 4.20; $\mathrm{P}<0.0001$ ) for study areas. Laboratory effects were

Table 4.19. Descriptive Statistics for ${ }^{239,240} \mathrm{Pu}(\mathrm{pCi} / \mathrm{g}$ ) in Vegetation (1983 Through 1993)

\begin{tabular}{|c|c|c|c|c|c|}
\hline & 100 Areas & 200 Areas & 300 Area & 600 Area & Offsite \\
\hline Median & 0.00027 & 0.00074 & 0.00026 & 0.00033 & 0.00017 \\
\hline Mean & 0.00142 & 0.00230 & 0.00050 & 0.00037 & 0.00024 \\
\hline Standard Error & 0.00112 & 0.00075 & 0.00018 & 0.00004 & 0.00003 \\
\hline Standard Deviation & 0.00592 & 0.00564 & 0.00072 & 0.00025 & 0.00031 \\
\hline Variance ${ }^{(a)}$ & 0.00004 & 0.00003 & 0.00000 & 0.00000 & 0.00000 \\
\hline Minimum & 0.00000 & 0.00003 & 0.00005 & -0.00009 & -0.00015 \\
\hline Maximum & 0.03160 & 0.04130 & 0.00256 & 0.00121 & 0.00217 \\
\hline & 28 & 57 & 17 & 51 & \\
\hline
\end{tabular}

(a) Values $=0.000$ indicate variance estimates were $<0.0005$. 
Table 4.20. ANOVA of Log-Transformed ${ }^{239,240} \mathrm{Pu}$ Concentrations in Vegetation by Study Area and Laboratory

\begin{tabular}{|c|c|c|c|c|c|}
\hline & $\underline{\mathrm{DF}}$ & $\begin{array}{l}\text { Sum of } \\
\text { Squares }\end{array}$ & $\begin{array}{c}\text { Mean } \\
\text { Square }\end{array}$ & F-Value & P-Value \\
\hline Laboratory & 1 & 0.4445 & $\overline{0.4445}$ & 3.4591 & 0.0640 \\
\hline Area & 4 & 6.3198 & 1.5799 & 12.2941 & $<0.0001$ \\
\hline Laboratory *Area & 4 & 1.3642 & 0.3411 & 2.6539 & 0.0335 \\
\hline Residual & 271 & 34.8267 & 0.1285 & & \\
\hline
\end{tabular}

not significant at the 5\% level (see also Table C.21). Scheffé's post hoc comparison of transformed means indicated that vegetation samples from the 200 Areas had higher concentrations than vegetation collected from the 100 Areas, 300 Area, 600 Area, and offsite locations $(P \leq 0.0030$; Table C.22).

\subsubsection{Trends}

Inspection of box plots for $239,240 \mathrm{Pu}$ in vegetation indicates possible decreases in concentrations from 1983 through 1993 (see Figure C.13). To determine if this perception was valid, median concentrations were log-transformed and regressed against years for each area (Table 4.21). The only significant regression was for the 100 Areas. Collectively, the regression analyses demonstrate little change over the study period (Figure 4.18). The log-transformed median plots also corroborate the relative elevation of $239,240 \mathrm{Pu}$ concentrations in 200 Areas vegetation samples compared to other study areas.

Table 4.21. Summary of Regression Analysis and ANOVA of Log Median (LM) ${ }^{239,240} \mathrm{Pu}$ in Vegetation

\begin{tabular}{|c|c|c|c|c|c|}
\hline \multirow[b]{2}{*}{ Area } & \multirow[b]{2}{*}{ Equation } & \multirow[b]{2}{*}{$\mathrm{R}^{2}$} & \multicolumn{3}{|c|}{ ANOVA } \\
\hline & & & $\underline{\mathrm{DF}}$ & F-Value & P-Value \\
\hline Offsite & $\mathrm{LM}=-2.337-0.0166 *$ Year & 0.0725 & 10 & 0.7035 & 0.4233 \\
\hline 100 Areas & $\mathrm{LM}=2.275-0.0675 *$ Year & 0.4059 & 8 & 4.7818 & 0.0650 \\
\hline 200 Areas & $\mathrm{LM}=-2.012-0.0128 *$ Year & 0.0222 & 7 & 0.1364 & 0.7246 \\
\hline 300 Area & $\mathrm{LM}=5.700-0.1060 *$ Year & 0.4011 & 7 & 4.0182 & 0.0918 \\
\hline 600 Area & $\mathrm{LM}=-2.073-0.0163 *$ Year & 0.0836 & 8 & 0.6387 & 0.4504 \\
\hline
\end{tabular}




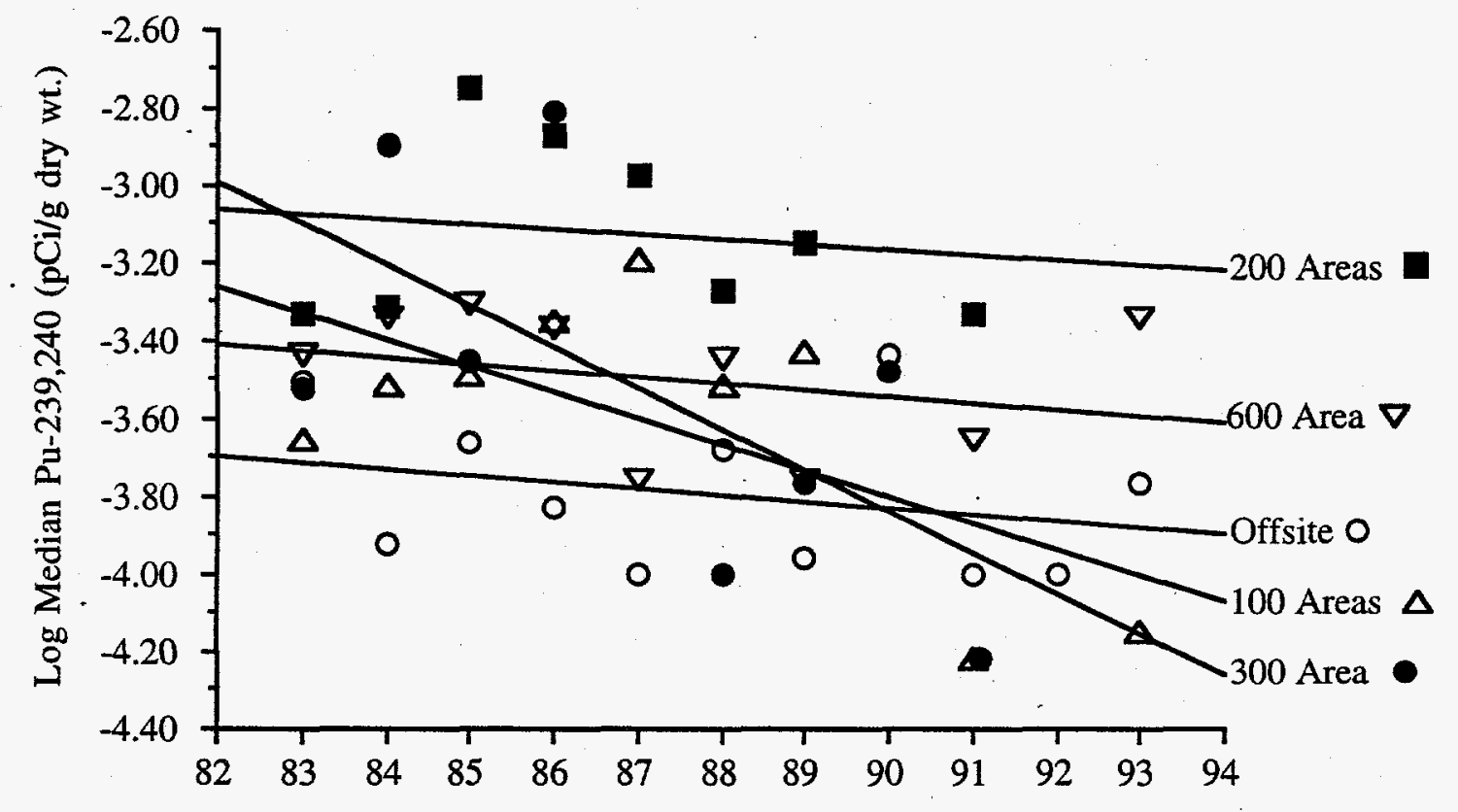

Figure 4.18. Regression Analyses of $239,240 \mathrm{Pu}$ in Vegetation by Study Area

\subsection{Americium-241}

Americium-241 was collected from ten soil sampling locations in the 200 Areas, 600 Area and offsite during the study period. Seven of the locations were in the 200 Areas. Americium-241 concentrations were low and concentrations in over $61 \%$ of the samples analyzed were not detected. Eight of the ten highest values were associated with the location East of the 200-West Gate. This is the same location that has historically had the highest ${ }^{238} \mathrm{Pu}$ and ${ }^{239,240} \mathrm{Pu}$ concentrations in the site surveillance monitoring project. The maximum value was $0.11( \pm 0.04) \mathrm{pCi} / \mathrm{g}$ of soil at that location. The median concentrations for the three study areas ranged from 0.0041 ( \pm to 0.0051 ) to 0.0044 $( \pm 0.0036) \mathrm{pCi} / \mathrm{g}$ (Figure 4.19) indicating that except for the East of the 200-West Gate location, ${ }^{241} \mathrm{Am}$ concentrations in soil were generally below the MDC $(0.05 \mathrm{pCi} / \mathrm{g})$. These observations were consistent with reported releases for the study period and suggest that elevated concentrations would most likely appear around the 200 Areas. Releases of 241 Am were greatest in the 200 Areas (Figure A.11). 


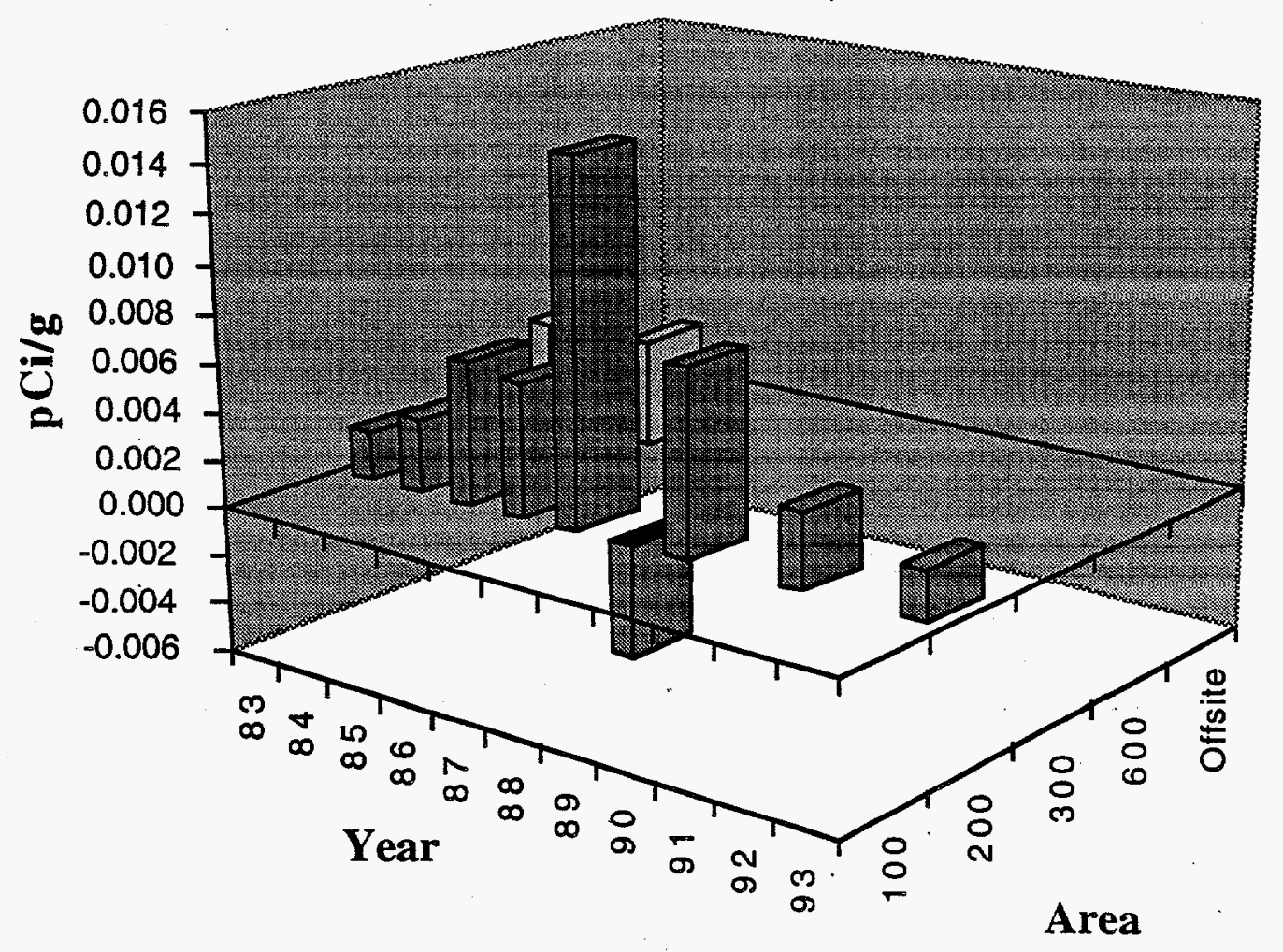

Figure 4.19. Annual Median Concentrations of 241 Am in Vegetation by Study Area. Black tops on histograms indicate a negative median; spaces where boxes are missing indicate less than two locations sampled. 


\subsection{Conclusions}

This evaluation of radionuclide concentrations found in soil and vegetation samples during the years from 1983 through 1993 demonstrated that when evaluated based on study area, specific areas at Hanford had statistically significant but slightly elevated concentrations of particular radionuclides compared to other onsite and offsite areas. The five study areas were the 100 Areas, the 200 Areas, the 300 Area, the undeveloped areas on site (600 Area), and offsite areas, including upwind and downwind sampling sites located on the Site perimeter to as far away as $72 \mathrm{~km}$ (45 mi). Sampling locations were located outside the boundaries of the specific operation areas. Specific observations on differences between study areas are listed below.

- The 100 Areas had concentrations of ${ }^{60} \mathrm{Co}$ comparable to the MDC of $0.02 \mathrm{pCi} / \mathrm{g}$ in soil; all other study areas had concentrations less than detection.

- The 200 Areas had a slight elevation of ${ }^{90} \mathrm{Sr},{ }^{137} \mathrm{Cs},{ }^{238} \mathrm{Pu},{ }^{239,240} \mathrm{Pu}$, and ${ }^{241} \mathrm{Am}$ in soil. These observations were generally reflected in vegetation samples. One sampling location, the East of the 200 West Gate, routinely had the highest concentrations of these radionuclides.

- The 300 Area had a slight elevation in $\mathrm{U}$ in soil samples.

For ${ }^{60} \mathrm{Co},{ }^{238} \mathrm{Pu}$, and ${ }^{241} \mathrm{Am}$, these apparent elevations in soil or vegetation samples hovered at the limit of detection, and these radionuclides essentially were less than detection levels at the other study areas. Where concentrations were distinctly elevated at onsite areas, the data indicated a patchy distribution that tended to increase the variance estimates for those areas. In many instances, the maximum measured concentrations of a radionuclide were found at the same sampling location in the area. This is anticipated for locations that were established in the monitoring design because of specific operations and facilities onsite. Results from each study area should not be construed to be a characterization of these study areas as that was not the objective of the monitoring sample design.

Over the 11-year study period, the trends in soil and vegetation data showed no change for those radionuclides that strongly sorbed to soil ( ${ }^{137} \mathrm{Cs}$ and $\mathrm{Pu}$ isotopes). Cesium- 137 concentrations would have been expected to decrease by about $30 \%$ over the study period due to radiological decay; however, concentrations were very close to the limits of detection $(0.02 \mathrm{pCi} / \mathrm{g})$ and no decrease was observed. Strontium-90 showed significant negative regressions over the study period in soil at all five study areas. The decrease in ${ }^{90} \mathrm{Sr}$ concentrations is due in part to radiological decay as well as a greater propensity for downward migration through the soil column and potential movement out of the sampling horizon. Concentrations of ${ }^{90} \mathrm{Sr}$ were well above the $\mathrm{MDC}$ of $0.005 \mathrm{pCi} / \mathrm{g}$. Decreasing trends were also noted for ${ }^{90} \mathrm{Sr}$ in vegetation samples; however they were statistically significant in two of the five locations. The lack of significance was due to the greater variability of the ${ }^{90} \mathrm{Sr}$ vegetation data compared to the soil data.

The magnitude of the radionuclide concentrations measured in soil and vegetation are well below levels hazardous to human or wildlife species. In many instances, onsite measurements were comparable to offsite measurements and in some cases less than offsite measurements. Offsite measurements may exceed onsite measurements in areas that have historically received greater amounts of precipitation and weapons testing fallout in the past. Measurements of penetrating radiation in these sampling areas as documented in annual Site surveillance reports are essentially at background levels and indicate no difference among any of the study areas defined in this report. 
Essentially, the concentrations of gamma emitting radionuclides monitored in soil are at levels so low that differences in penetrating radiation are not detectable. Dose rates from alpha emitters would not be detected by thermoluminescent dosimetry.

Reductions in the collection of soil and vegetation samples were implemented in 1990 because of the extensive scope of the existing soil and vegetation data bases, a change in analytical subcontractors, and the change in the Site mission from production to clean-up and restoration. As indicators of potential fugitive emissions resulting from an unplanned release, soil and vegetation surveillance address two concerns. Because of the low levels associated with vegetation samples, vegetation is better suited for monitoring acute releases; however, assessing long term build-up of radioactivity in the environment is better accommodated in soil because of the poor accumulation of these radionuclides by plants. A low level release may not be detected in a soil sample; however, it would be measured in a vegetation sample because of its significantly lower initial concentration of these radionuclides in vegetation. These considerations have molded the present sampling strategy used for Site surveillance. 


\subsection{References}

This section contains references cited in the text of this report. At the end of this listing is a separate listing of Hanford Site Annual Surveillance reports for the period 1983 through 1993. In 1983, both an offsite surveillance report and an onsite monitoring report were issued by PNL.

Antonio, E. J. 1994. Radionuclide Concentrations in Agricultural Products Near the Hanford Site, 1982 through 1992. PNL-9455, Pacific Northwest Laboratory, Richland, Washington.

Antonio, E. J., T. M. Poston, and W. H. Rickard, Jr. 1993. Radiological Survey of Shoreline Vegetation from the Hanford Reach of the Columbia River, 1990 - 1992. PNL-8797, Pacific Northwest Laboratory, Richland, Washington.

Booth, R. S. 1976. "A Systems Analysis Model for Calculating Radionuclide Transport Between Receiving Waters and Bottom Sediments." In Environmental Toxicity of Aquatic Radionuclides: Models and Mechanisms, eds. M. W. Miller and J. W. Stannard, pp. 133-164. Ann Arbor Science, Ann Arbor, Michigan.

Coughtrey, P. J., D. Jackson, and M. C. Thorne. 1985. Radionuclide Distribution and Transport in Terrestrial and Aquatic Ecosystems, A Compendium of Data. Vol. 6 of 6. A. A. Balkema, Rotterdam, Netherlands.

Cooper, A. T., and R. K. Woodruff. 1993. Investigations of Exposure Rates and Radionuclide and Trace Metal Distributions Along the Hanford Reach of the Columbia River. PNL-8789, Pacific Northwest Laboratory, Richland, Washington.

Denham, D. H., R. L. Dirkes, R. W. Hanf, T. M. Poston, M. E. Thiede, and R. K. Woodruff. 1993. Phase I Summaries of Radionuclide Concentration Data for Vegetation, River Water, Drinking Water and Fish. PNWD-2145 HEDR, Battelle, Pacific Northwest Laboratories, Richland, Washington.

Dirkes, R. L. 1994. Summary of Radiological Monitoring of Columbia River Water Along the Hanford Reach, 1980 to 1989. PNL-9223, Pacific Northwest Laboratory, Richland, Washington.

Eberhardt, L. E., and R. O. Gilbert. 1980. "Statistics and Sampling in Transuranic Studies." In Transuranic Elements in the Environment, ed. W. C. Hanson, pp. 173-186. National Technical Information Center, Springfield, Virginia.

Eberhardt, L. E., L. L. Cadwell, K. R. Price, and D. W. Carlile. 1989. Trends in Radionuclide Concentrations for Selected Wildlife and Food Products Near the Hanford Site From 1971 to 1988. PNL-6992, Pacific Northwest Laboratory, Richland, Washington. 
ERDA. 1975. Final Environmental Statement, Waste Management Operations, Hanford Reservation, Richland, Washington. ERDA-1538, U.S. Energy Research and Development Administration, Washington, D.C.

Foster, G. R., and T. E. Hakonson. 1987. "Erosional Losses of Fallout Plutonium." In Environmental Research on Actinide Elements, eds. J. E. Pinder, J. J. Alberts, K. W. McLeod, and R. G. Schreckhise, pp. 225-253. CONF-841142, U.S. Department of Energy. National Technical Information Center, Springfield, Virginia.

Fox-Williams, K. S. 1993. "Offsite Impact of Unmonitored Releases at Hanford." In Environmental Health Physics, Proceedings of the 26th Year Topical Meeting of the Health Physics Society, eds. R. L. Kathern, D. H. Denham, K. Salmon, and D. Felton, pp. 241-253. January 24-28, 1993, Coeur d'Alene, Idaho. Research Enterprises, Inc., Richland, Washington.

Friedlander, G., J. W. Kennedy, and J. M. Miller. 1964. Nuclear and Radiochemistry, Second Edition. John Wiley \& Sons, New York.

Gilbert, R. O., and R. R. Kinnison. 1981. "Statistical Methods for Estimating the Mean and Variance from Radionuclide Data Sets Containing Negative, Unreported, or Less Than Values." Health Phys. 40:377-390.

HEDL. 1981. Chapter 18, FFTF Technical Specifications, FFTF Final Safety Analysis Report. Hanford Engineering Development Laboratory, Richland, Washington.

Heeb, C. M. 1994. Radionuclide Releases to the Atmosphere from Hanford Operations, 1944-1972. PNWD-2222 HEDR, Battelle, Pacific Northwest Laboratories, Richland, Washington.

Heeb, C. M., and D. J. Bates. 1994. Radionuclide Releases to the Columbia River from Hanford Operations, 1944-1971. PNWD-2223 HEDR, Battelle, Pacific Northwest Laboratories, Richland, Washington.

Jaquish, R. E., and R. W. Bryce (eds). 1990. Hanford Site Environmental Report for Calendar Year 1989. PNL-6825, Pacific Northwest Laboratory, Richland, Washington.

Klepper, E. L., L. E. Rogers, J. D. Hedlund, and R. G. Schreckhise. 1979. Radioactivity Associated with Biota and Soils of the 216-A-24 Crib. PNL-1948, Pacific Northwest Laboratory, Richland, Washington.

MacLellan, J. A., T. P. Lynch, G. A. Rieksts, and R. L. Brodzinski. 1993. "Identification of Environmentally Derived Cesium-137 Burdens in a Worker Population." In Environmental Health Physics, Proceedings of the 26th Year Topical Meeting of the Health Physics Society, eds. R. L. Kathern, D. H. Denham, K. Salmon, and D. Felton, pp. 171-179. January 24-28, 1993, Coeur d'Alene, Idaho. Research Enterprises, Inc., Richland, Washington. 
Patton, G. W., and A. T. Cooper. 1993. Air Pathway Effects of Nuclear Materials Production at the Hanford Site, 1983 Through 1992. PNL-8830, Pacific Northwest Laboratory, Richland, Washington.

Perkins, R. W., and C. W. Thomas. 1980. "Worldwide Fallout." In Transuranic Elements in the Environment, ed W. C. Hanson, pp. 53-82. DOE/TIC-22800, U.S. Department of Energy. National Technical Information Service, Springfield Virginia.

Poston, T, M. 1990. A Survey of Elevated Levels of Uranium North of the 300 Area on the Hanford Site. PNL-7271, Pacific Northwest Laboratory, Richland, Washington.

Poston, T, M. 1994. Trends in Radionuclide Concentrations in Hanford Reach Fish, 1982 Through 1992. PNL-9960, Pacific Northwest Laboratory, Richland, Washington.

Poston, T, M., and A. T. Cooper. 1994. A Qualitative Evaluation of Radionuclide Concentrations in Hanford Site Wildlife, 1983 Through 1992. PNL-10174, Pacific Northwest Laboratory, Richland, Washington.

Poston, T, M., and D. C. Klopfer. 1988. "Concentration Factors Used in the Assessment of Radiation Dose to Consumers of Fish: A Review of 27 Radionuclides." Health Phys. 55:751-766.

Price, K. R. 1987. "Soil and Vegetation Monitoring." In Environmental Monitoring at Hanford for 1986, pp. 3.46-3.50, PNL-6120, Pacific Northwest Laboratory, Richland; Washington.

Price, K. R. 1991. The Depth Distribution of ${ }^{90} \mathrm{Sr},{ }^{137} \mathrm{Cs}$, and ${ }^{239,240} \mathrm{Pu}$ in Soil Profile Samples. Radiochim. Acta. 54:145-147.

Price, K. R., and R. R. Kinneson. 1982. Uranium and Other Heavy Metals in Soil and Vegetation from the Hanford Environs. PNL-4466, Pacific Northwest Laboratory, Richland, Washington.

Seaborg, G. T. 1973. "Uranium and Compounds." In Encyclopedia of Chemistry, Third Edition, ed. C. A. Hompel and G. G. Hawley. Van Nostern Reinhold Co., New York.

Sokal, R. R., and F. J. Rohlf. 1981. Biometry. Second Edition, W. H. Freeman and Company, New York.

Sula, M. J. 1980. Radiological Survey of Exposed Shoreline and Islands of the Columbia River between Vernita and the Snake River Confluence. PNL-3127, Pacific Northwest Laboratory, Richland, Washington.

Tiller, B. L., and T. M. Poston. 1992. Uranium Concentrations in Asparagus. PNL-8068, Pacific Northwest Laboratory, Richland, Washington. 
U.S. Department of Energy (DOE). 1990. "Radiation Protection of the Public and the Environment." DOE Order 5400.5.

U.S. Department of Energy (DOE). 1994. Environmental Monitoring Plan. DOE/RL 91-50, Rev. 1, U.S. Department of Energy, Richland, Washington.

Wildung, R. E., T. R. Garland, and J. E. Rogers. 1987. "Plutonium Interactions with Soil Microbial Metabolites: Effect on Plutonium Sorption by Soil." In Environmental Research on Actinide Elements. Eds. J. E. Pinder, J. E., J. J. Alberts, K. W. McLeod, and R. G. Schreckhise, pp. 1-25. CONF-841142, U.S. Department of Energy. National Technical Information Center, Springfield, Virginia.

Woodruff, R. K. 1987. "Air Monitoring." In Environmental Monitoring at Hanford for 1986. PNL6120, Pacific Northwest Laboratory, Richland, Washington.

Hanford Site Annual Environmental Reports

Dirkes, R. L., R. W. Hanf, R. K. Woodruff, and R. E. Lundgren (eds.). 1994. Hanford Site Environmental Report for Calendar Year 1993. PNL-9823, Pacific Northwest Laboratory, Richland, Washington.

Woodruff, R. K., R. W. Hanf, and R. E. Lundgren (eds.). 1993. Hanford Site Environmental Report for Calendar Year 1992. PNL-8682, Pacific Northwest Laboratory, Richland, Washington.

Woodruff, R. K., R. W. Hanf, and R. E. Lundgren (eds.). 1992. Hanford Site Environmental Report for Calendar Year 1991. PNL-8148, Pacific Northwest Laboratory, Richland, Washington.

Woodruff, R. K., R. W. Hanf, M. G. Hefty, and R. E. Lundgren (eds.). 1991. Hanford Site Environmental Report for Calendar Year 1990. PNL-7930, Pacific Northwest Laboratory, Richland, Washington.

Jaquish, R. E., and R. W. Bryce. 1990. Hanford Site Environmental Report for Calendar Year 1989. PNL-7346, Pacific Northwest Laboratory, Richland, Washington.

Jaquish, R. E., and R. W. Bryce. 1989. Hanford Site Environmental Report for Calendar Year 1988. PNL-6825, Pacific Northwest Laboratory, Richland, Washington.

Jaquish, R. E., and P. J. Mitchell. 1988. Environmental Monitoring at Hanford 1987. PNL-6464, Pacific Northwest Laboratory, Richland, Washington.

PNL 1987. Environmental Monitoring at Hanford for 1986. 1987, PNL-6120, Pacific Northwest Laboratory, Richland, Washington. 
Price, K. R. 1986. Environmental Monitoring at Hanford for 1985. PNL-5817, Pacific Northwest Laboratory, Richland, Washington.

Price, K. R., J.M.V. Carlile, R. L. Dirkes, R. E. Jaquish, M. S. Trevathan, and R. K. Woodruff. 1985. Environmental Monitoring at Hanford for 1984. PNL-5407, Pacific Northwest Laboratory, Richland, Washington.

Price, K. R., J.M.V. Carlile, R. L. Dirkes, and M. S. Trevathan. 1984. Environmental Surveillance at Hanford for 1983. PNL-5038, Pacific Northwest Laboratory, Richland, Washington.

Price, K. R., P. J. Blumer, J.M.V. Carlile, R. L. Dirkes, M. S. Trevathan. 1984. Environmental Status of the Hanford Site for CY 1983. PNL-5039, Pacific Northwest Laboratory, Richland, Washington.

Sula, M. J., J.M.V. Carlile, K. R. Price, and W. D. McCormack. 1983. Environmental Surveillance at the Hanford Site for CY 1982. PNL-4657, Pacific Northwest Laboratory, Richland, Washington. 


\section{Appendix A}

Atmospheric Source Terms 

This appendix contains histograms of atmospheric releases of radionuclides by area on the Hanford Site. These data where taken from releases reported in 11 annual site surveillance reports for the period 1983 through 1993 (see Section 6.0). Generally, those areas showing the greatest releases also tend to have the highest concentrations in soil and vegetation. Where data are lacking indicates that no releases were reported. 


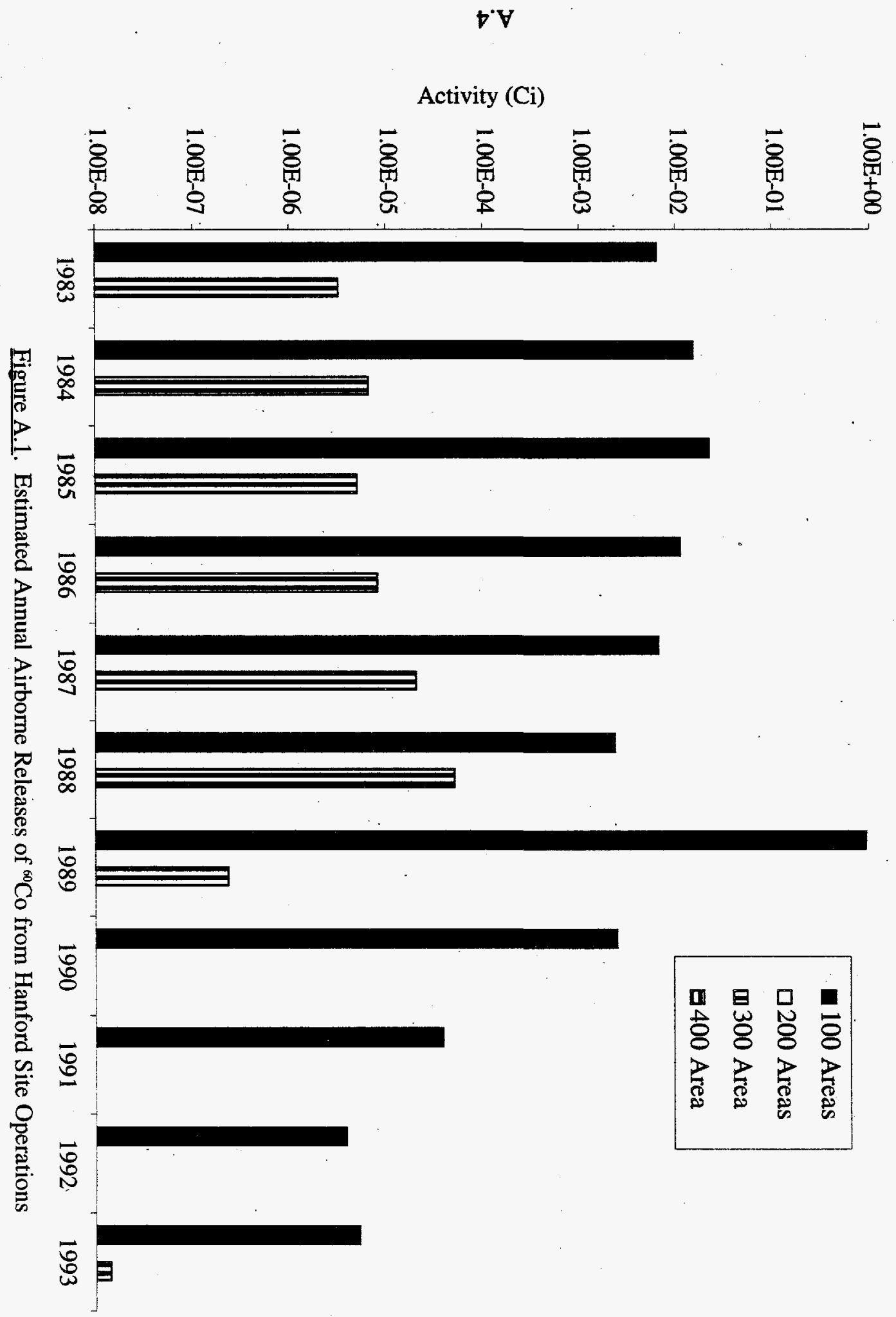



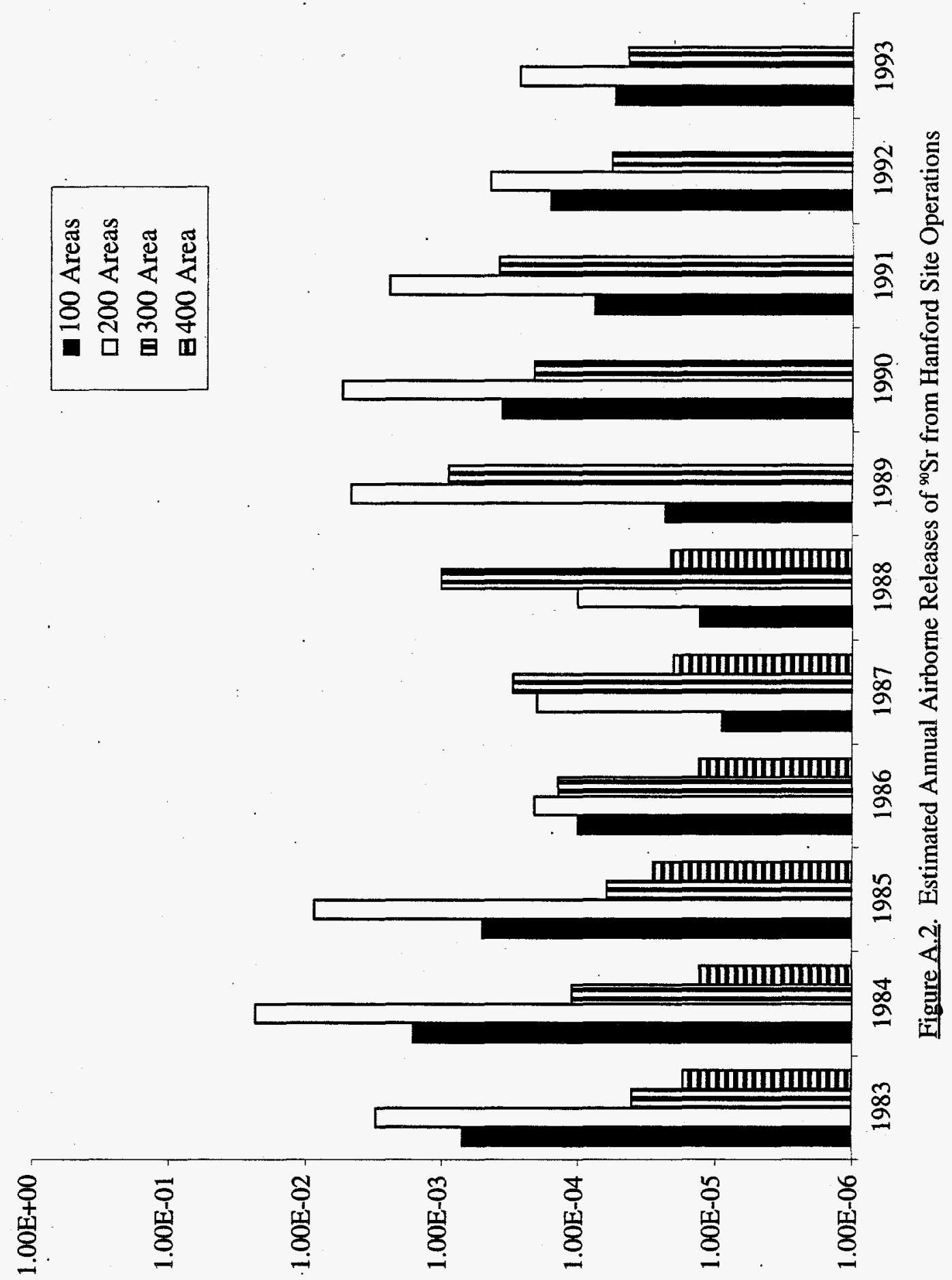

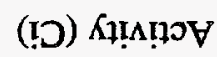




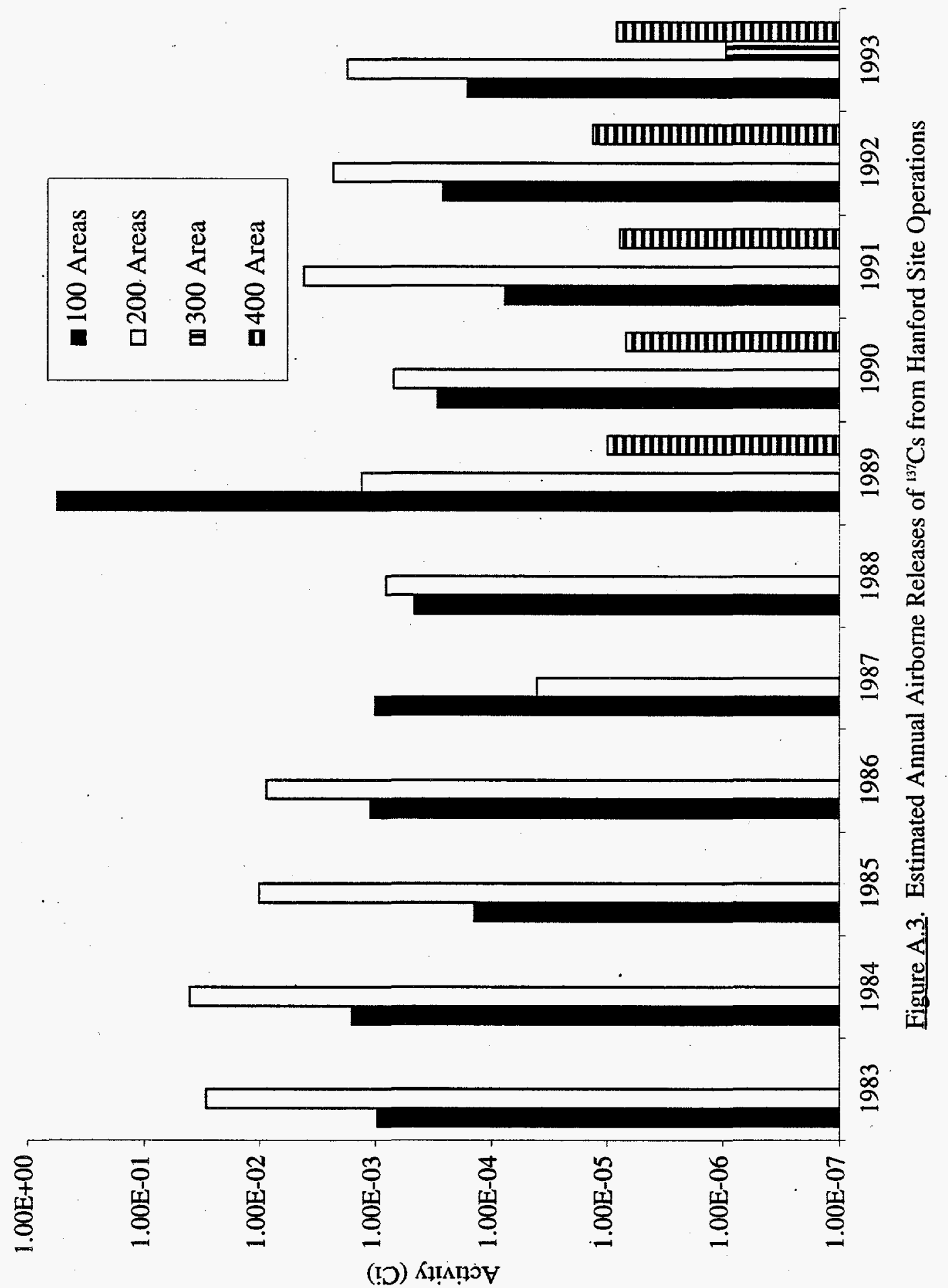

A. 6 


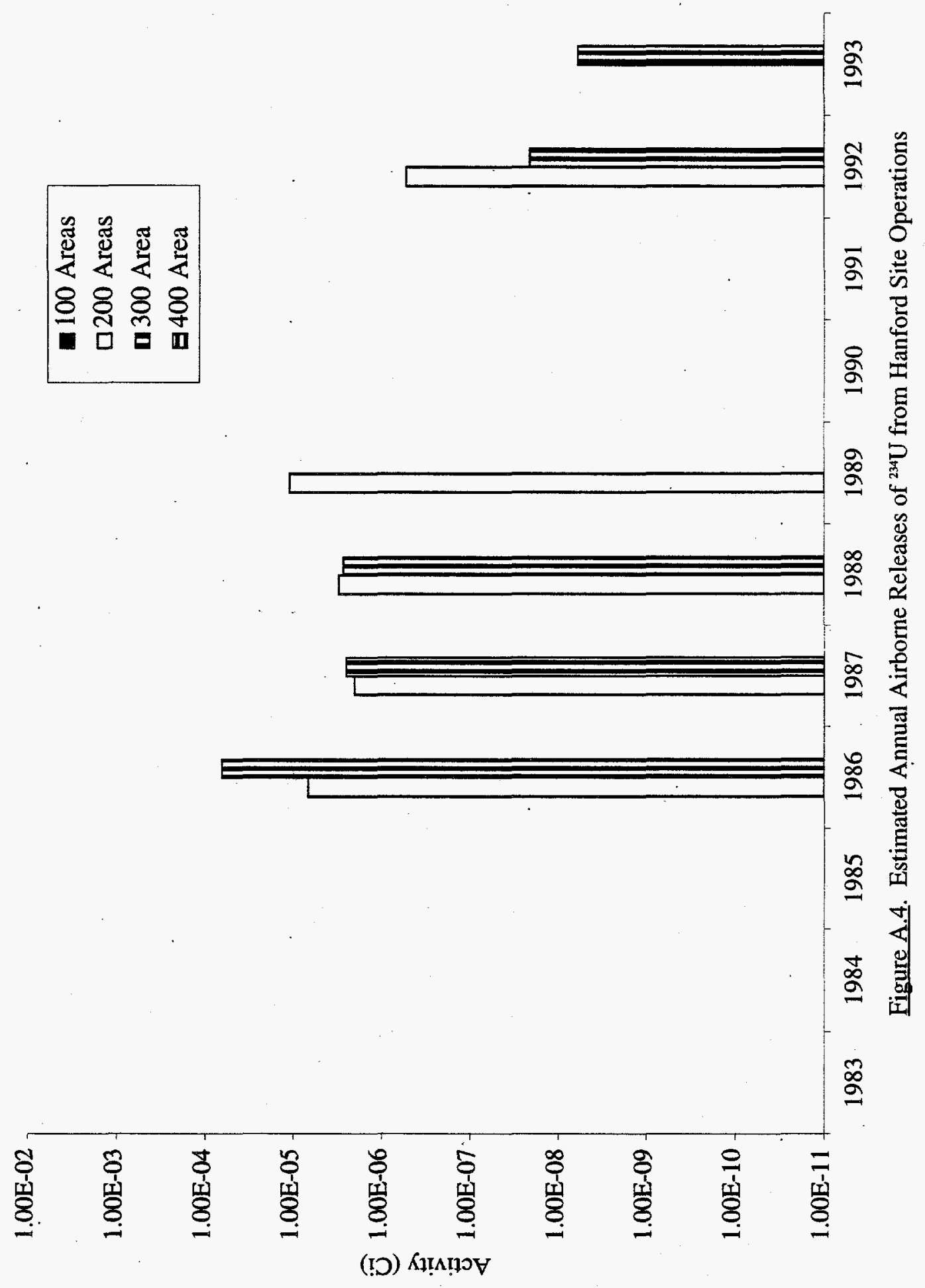

A. 7 


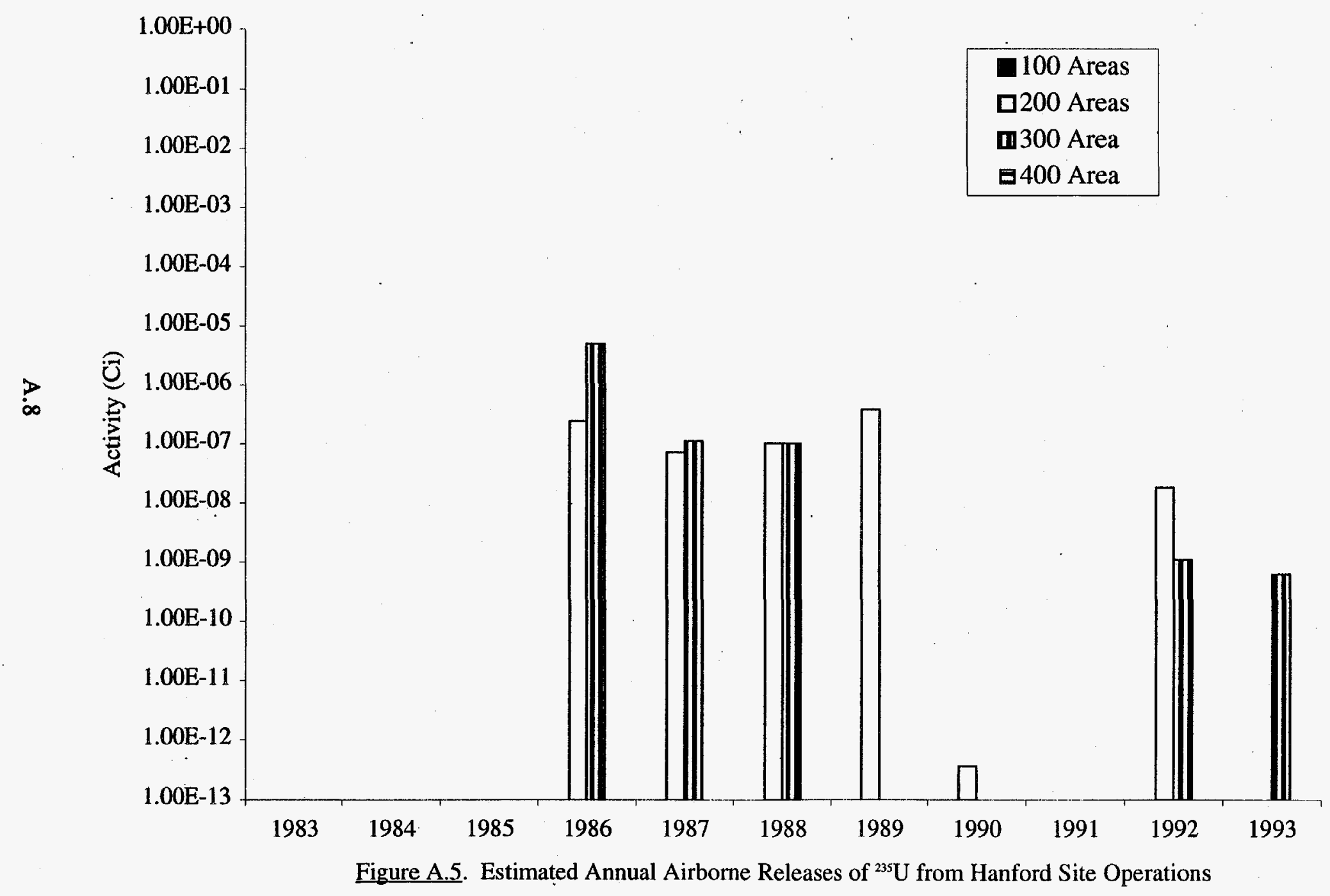




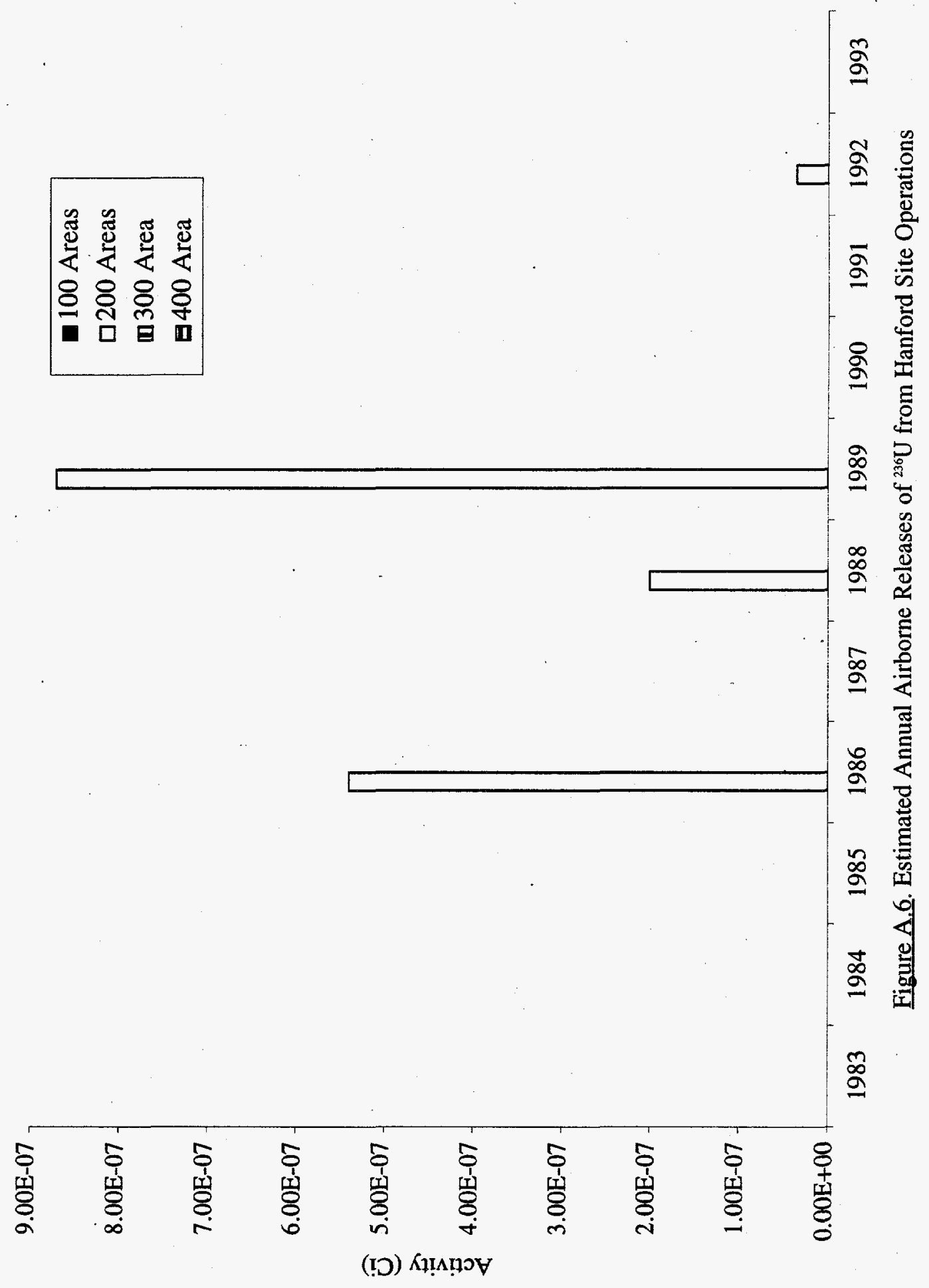

\section{A. 9}



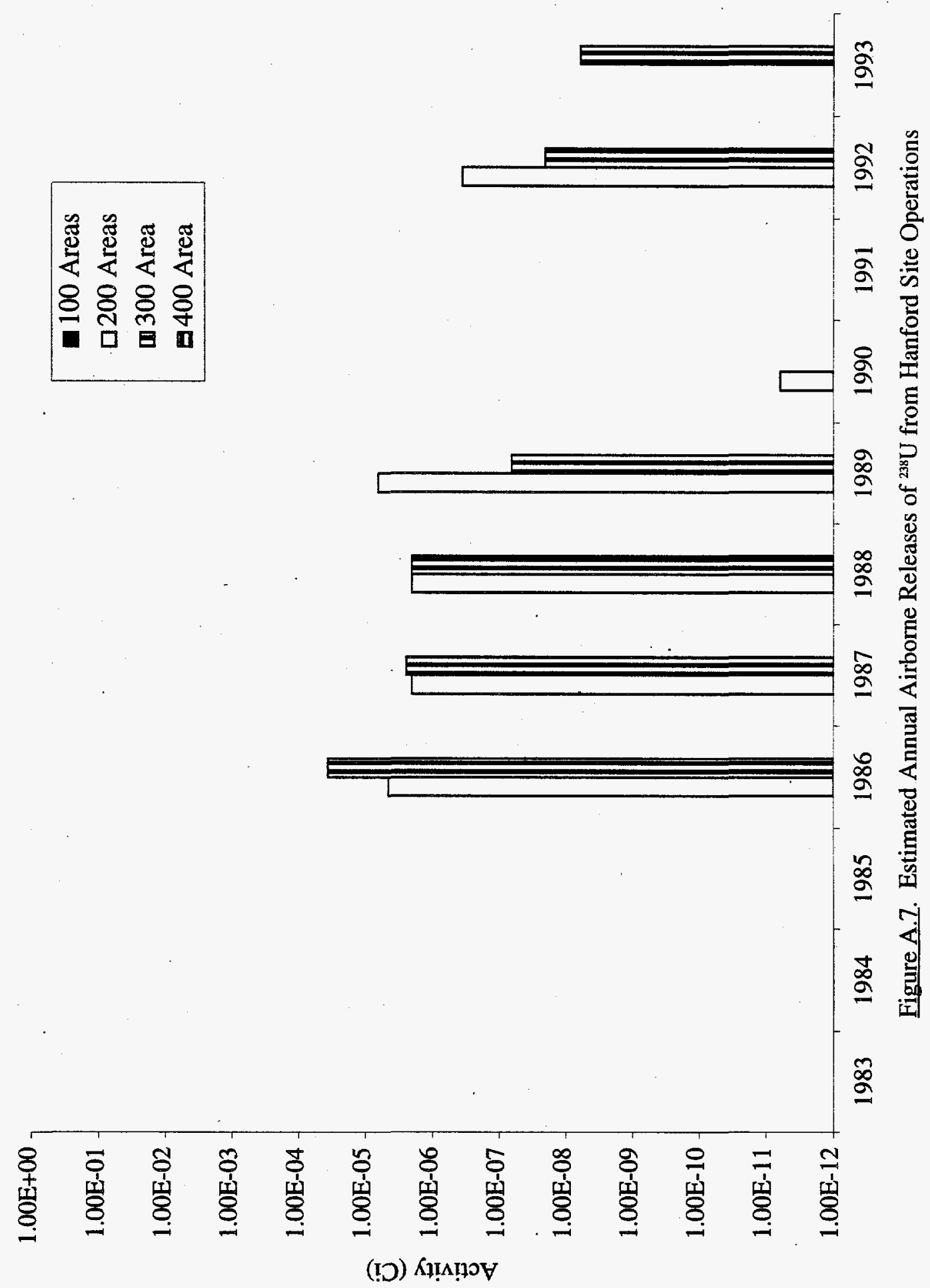

A. 10 


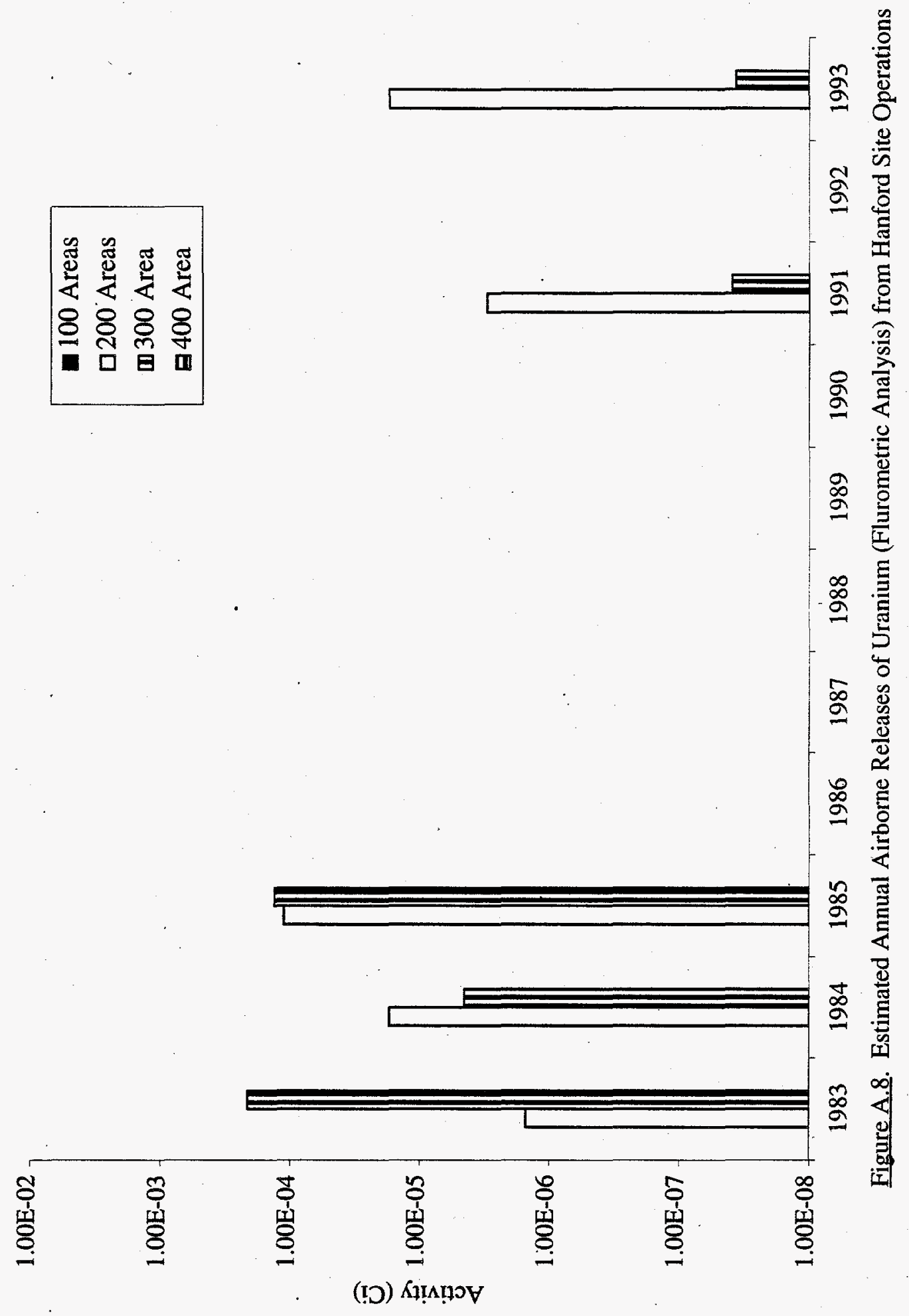

A. 11 


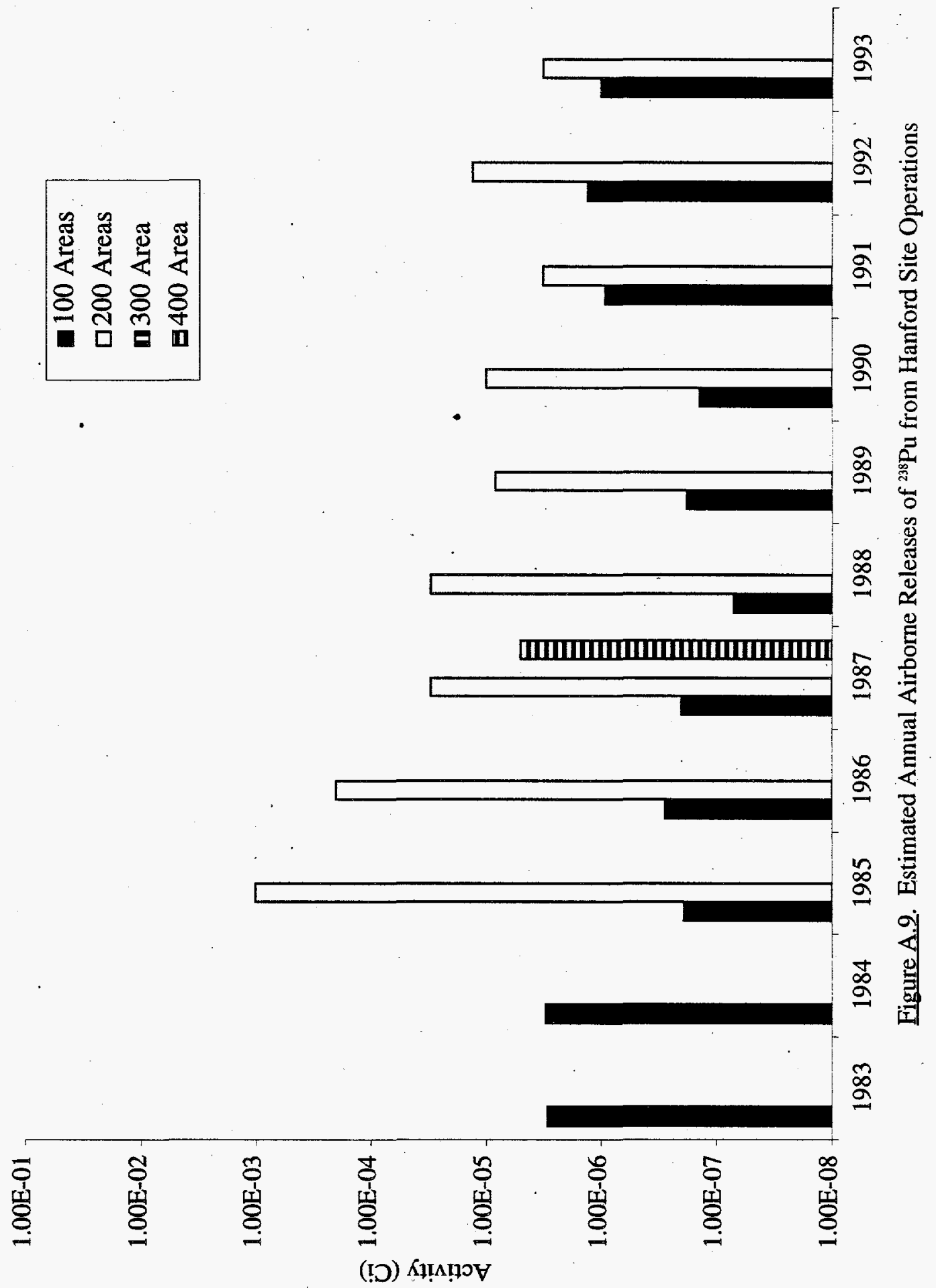

A. 12 


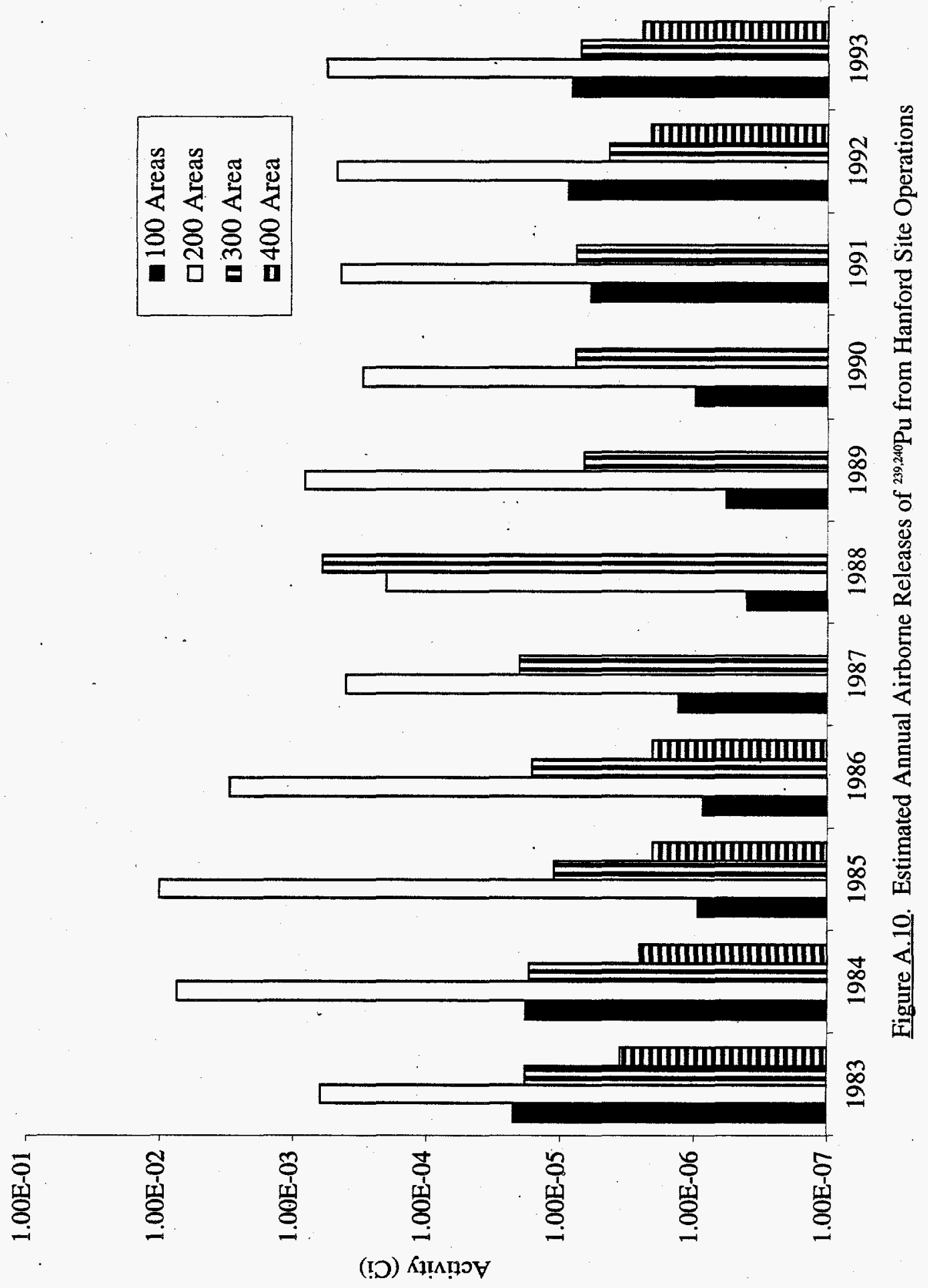

A. 13 


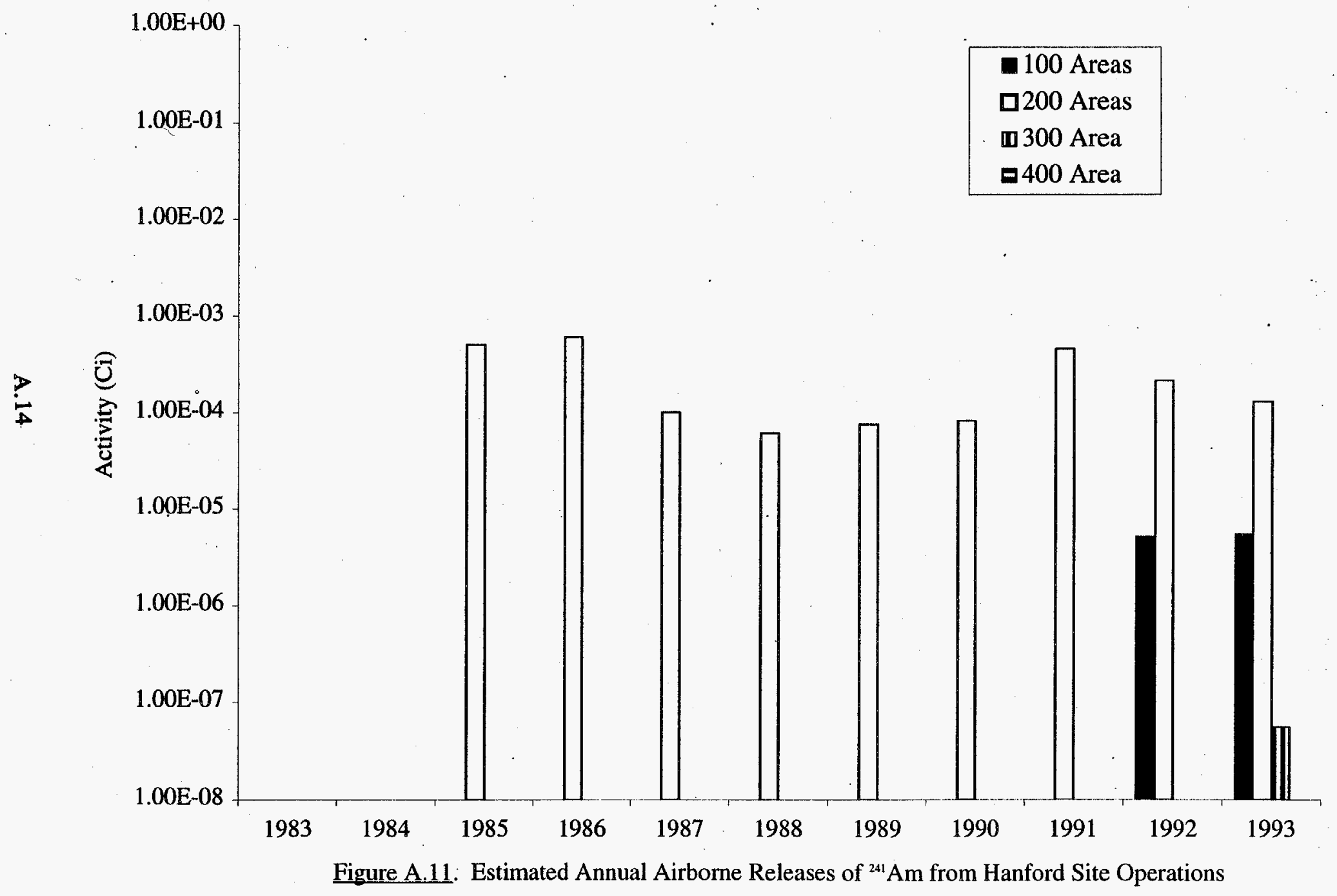




\section{Appendix B}

Soil and Vegetation Sampling Frequency 

Table B.1. Number of Radionuclide Analyses in Soil by Sample Site Location

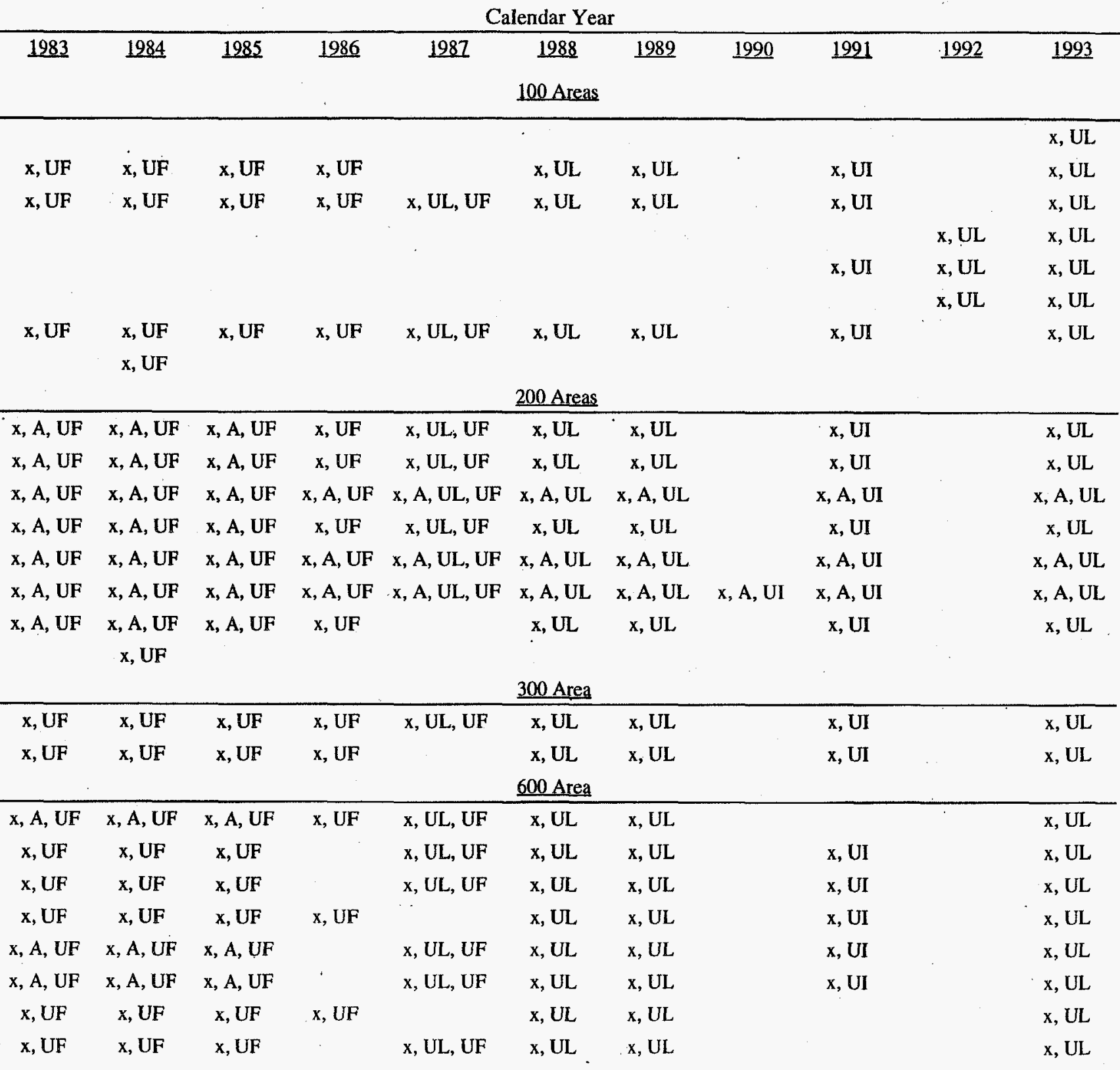


Table B.1. (Contd)

\begin{tabular}{|c|c|c|c|c|c|c|c|c|c|c|c|c|}
\hline $\begin{array}{c}\text { Map } \\
\text { Number }\end{array}$ & & \multicolumn{11}{|c|}{ Calendar Year } \\
\hline 26 & Wahluke Slope & $\mathrm{x}, \mathrm{UF}$ & $\mathrm{x}, \mathrm{UF}$ & $\mathrm{x}, \mathrm{UF}$ & $\mathrm{x}, \mathrm{UF}$ & $\mathrm{x}, \mathrm{UL}, \mathrm{UF}$ & $\mathrm{x}, \mathrm{UL}$ & $\mathrm{x}, \mathrm{UL}$ & $\mathrm{x}, \mathrm{UI}$ & & & $x$, UL \\
\hline 27 & Berg Ranch & $\mathrm{x}, \mathrm{UF}$ & $x, U F$ & $\mathrm{x}, \mathrm{UF}$ & $x$, UF & $\mathrm{x}, \mathrm{UL}, \mathrm{UF}$ & $\mathrm{x}, \mathrm{UL}$ & $x, U L$ & $\mathrm{x}, \mathrm{UI}$ & & & $\mathrm{x}, \mathrm{UL}$ \\
\hline 28 & Ringold & $\mathrm{x}, \mathrm{UF}$ & $\mathrm{x}, \mathrm{UF}$ & $\mathrm{x}, \mathrm{UF}$ & $\mathrm{x}, \mathrm{UF}$ & $\mathrm{x}, \mathrm{UL}, \mathrm{UF}$ & $\mathrm{x}, \mathrm{UL}$ & $x, U L$ & $\mathbf{x}, \mathbf{U I}$ & $\mathrm{x}, \mathrm{UI}$ & $\mathrm{x}, \mathrm{UI}, \mathrm{UL}$ & $\mathrm{x}, \mathrm{UL}$ \\
\hline 31 & Sagemoor Farm & $\mathrm{x}$ & $\mathrm{x}, \mathrm{A}$ & $\mathrm{x}, \mathrm{A}$ & $\mathrm{x}, \mathrm{A}$ & $\mathrm{x}, \mathrm{A}, \mathrm{UL}$ & $\mathrm{x}, \mathrm{A}, \mathrm{UL}$ & $\mathrm{x}, \mathrm{A}, \mathrm{UL}$ & $\mathrm{x}, \mathrm{A}, \mathrm{UI}$ & $\mathrm{x}, \mathrm{A}, \mathrm{UI}$ & x, A, UI, UL & $\mathrm{x}, \mathrm{A}, \mathrm{UL}$ \\
\hline 32 & Byers Landing & $\mathrm{x}, \mathrm{UF}$ & $\mathrm{x}, \mathrm{UF}$ & $\mathrm{x}, \mathrm{UF}$ & $\mathrm{x}, \mathrm{UF}$ & $\mathrm{x}, \mathrm{UL}, \mathrm{UF}$ & $\mathrm{x}, \mathrm{UL}$ & $\mathrm{x}, \mathrm{UL}$ & $\mathrm{x}, \mathrm{UI}$ & $\mathrm{x}, \mathrm{UI}$ & $\mathrm{x}, \mathrm{UL}$ & $x$, UL \\
\hline 33 & Riverview - Harris & $\mathrm{x}, \mathrm{UF}$ & $\mathrm{x}, \mathrm{UF}$ & $\mathrm{x}, \mathrm{UF}$ & $\mathrm{x}, \mathrm{UF}$ & $\mathrm{x}, \mathrm{UL}, \mathrm{UF}$ & $\mathrm{x}, \mathrm{UL}$ & $\mathrm{x}, \mathrm{UL}$ & & $\mathrm{x}, \mathrm{UI}$ & $\mathrm{x}, \mathrm{UI}, \mathrm{UL}$ & $x, \mathrm{UL}$ \\
\hline 34 & Benton City & $\mathrm{x}, \mathrm{UF}$ & $\mathrm{x}, \mathrm{UF}$ & $\mathrm{x}, \mathrm{UF}$ & $\mathrm{x}, \mathrm{UF}$ & $\mathrm{x}, \mathrm{UL}, \mathrm{UF}$ & $\mathrm{x}, \mathrm{UL}$ & $\mathrm{x}, \mathrm{UL}$ & & & & $\mathrm{x}, \mathrm{UL}$ \\
\hline 35 & Sunnyside & $\mathrm{x}, \mathrm{A}, \mathrm{UF}$ & $\mathrm{x}, \mathrm{A}, \mathrm{UF}$ & $\mathrm{x}, \mathrm{A}, \mathrm{UF}$ & $\mathrm{x}, \mathrm{A}, \mathrm{UF}$ & $\mathrm{x}, \mathrm{A}, \mathrm{UL}, \mathrm{UF}$ & $\mathrm{x}, \mathrm{A}, \mathrm{UL}$ & $\mathrm{x}, \mathrm{A}, \mathrm{UL}$ & $\mathrm{x}, \mathrm{A}, \mathrm{UI}$ & $\mathrm{x}, \mathrm{A}, \mathrm{UI}$ & $\mathrm{x}, \mathrm{A}, \mathrm{UL}$ & $\mathrm{x}, \mathrm{A}, \mathrm{UL}$ \\
\hline 36 & McNary Dam & & & $\mathbf{x}, \mathbf{U F}$ & $\mathrm{x}, \mathrm{UF}$ & $\mathrm{x}, \mathrm{UL}, \mathrm{UF}$ & $\mathrm{x}, \mathrm{UL}$ & $x, \mathrm{UL}$ & $\mathbf{x}, \mathbf{U I}$ & & & \\
\hline 40 & Othello & . & & & $\mathrm{x}, \mathrm{UF}$ & $\mathrm{x}, \mathrm{UL}, \mathrm{UF}$ & $\mathrm{x}, \mathrm{UL}$ & $\mathrm{x}, \mathrm{UL}$ & $\mathbf{x}, \mathbf{U I}$ & $\mathrm{x}$ & & \\
\hline 41 & Connell & & & & $\mathrm{x}, \mathrm{UF}$ & $\mathrm{x}, \mathrm{UL}, \mathrm{UF}$ & $\mathrm{x}, \mathrm{UL}$ & $\mathrm{x}, \mathrm{UL}$ & $\mathbf{x}, \mathbf{U I}$ & $\mathrm{x}, \mathrm{UI}$ & & \\
\hline 42 & Moses Lake & & & & $\mathrm{x}, \mathrm{UF}$ & $\mathrm{x}, \mathrm{UL}, \mathrm{UF}$ & $\mathrm{x}, \mathrm{UF}$ & $\mathrm{x}, \mathrm{UF}$ & $\mathrm{x}, \mathrm{UI}$ & $\mathrm{x}, \mathrm{UI}$ & & \\
\hline
\end{tabular}

Key: x= Gamma Spectrum (Co-60, Cs-137), Sr-90, Pu-iso; A = Am-241; UF = U fluorometric; UL = U Low energy photon (LEPS); UI = U alpha spec. 
Table B.2. Number of Radionuclide Analyses in Vegetation by Sample Site Location, 1983 Through 1993

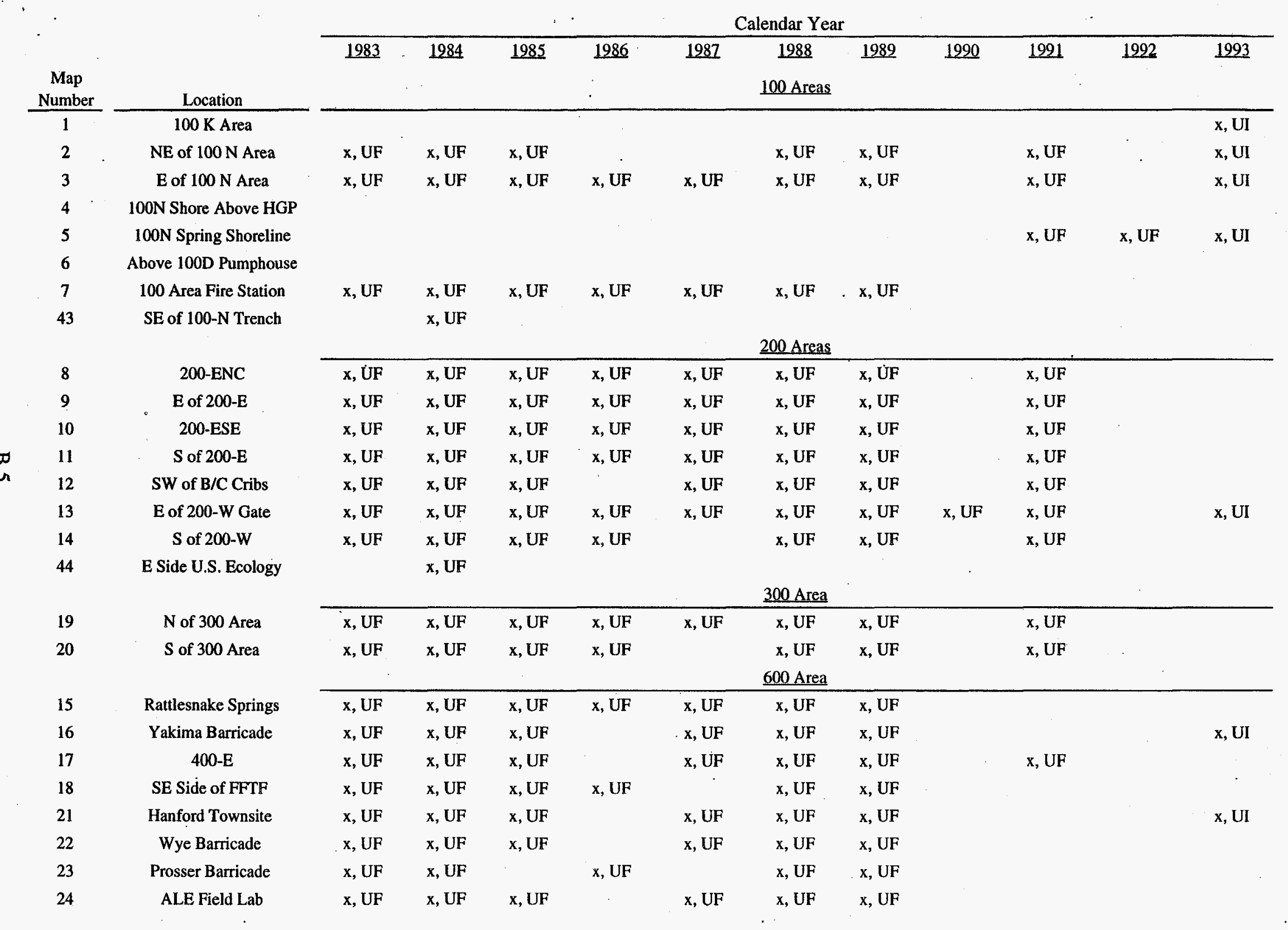




\begin{tabular}{|c|c|c|c|c|c|c|c|c|c|c|c|c|}
\hline \multirow[b]{3}{*}{$\begin{array}{c}\text { Map } \\
\text { Number }\end{array}$} & \multirow[b]{3}{*}{ Location } & \multicolumn{11}{|c|}{ Calendar Year } \\
\hline & & 1983 & 1984 & 1985 & 1986 & 1987 & 1988 & 1989 & 1990 & 1991 & 1992 & 1993 \\
\hline & & \multicolumn{11}{|c|}{ Offsite } \\
\hline 25 & N End Vernita Bridge & $\mathbf{x}, \mathbf{U F}$ & $\mathrm{x}, \mathrm{UF}$ & $\mathrm{x}, \mathrm{UF}$ & & & $\mathrm{x}, \mathrm{UF}$ & $\mathrm{x}, \mathrm{UF}$ & & & & \\
\hline 26 & Wahiluke Slope & $\mathbf{x}, \mathrm{UF}$ & $\mathbf{x}, \mathbf{U F}$ & $\mathbf{x}, \mathrm{UF}$ & & $\mathrm{x}, \mathrm{UF}$ & $\mathrm{x}, \mathrm{UF}$ & $\mathrm{x}$, UF & $\mathrm{x}, \mathrm{UF}$ & & & \\
\hline 27 & Berg Ranch & $\mathrm{x}, \mathrm{UF}$ & $\mathrm{x}, \mathrm{UF}$ & $\mathrm{x}, \mathrm{UF}$ & & $\mathrm{x}, \mathrm{UF}$ & $x$, UF & $\mathrm{x}, \mathrm{UF}$ & $\mathrm{x}, \mathrm{UF}$ & & & \\
\hline 28 & Ringold & $x$, UF & $\mathrm{x}, \mathrm{UF}$ & $\mathrm{x}, \mathrm{UF}$ & $\mathrm{x}, \mathrm{UF}$ & $\mathrm{x}, \mathrm{UF}$ & $x$, UF & $\mathrm{x}, \mathrm{UF}$ & $\mathrm{x}, \mathrm{UF}$ & $\mathrm{x}, \mathrm{UF}$. & $\mathrm{x}, \mathrm{UF}$ & $\mathrm{x}, \mathrm{UI}$ \\
\hline 29 & W End of Fir Road & $x, U F$ & $\mathbf{x}, \mathbf{U F}$ & $x, U F$ & $\mathrm{x}, \mathrm{UF}$ & $x$, UF & $x$, UF & $x, U F$ & $?$, UF & & & \\
\hline 30 & . Taylor Flats No. 2 & $\mathbf{x}, \mathrm{UF}$ & $\mathbf{x}$, UF & $x$, UF & $\mathbf{x}, \mathbf{U F}$ & $x$, UF & $\mathbf{x}, \mathrm{UF}$ & $\mathrm{x}, \mathrm{UF}$ & $\mathbf{x}, \mathrm{UF}$ & & & \\
\hline 31 & Sagemoor Farm & $x_{x}$ UF & $x$, UF & $\mathrm{x}, \mathrm{UF}$ & & $\mathrm{x}, \mathrm{UF}$ & $x, U F$ & $x, U F$ & $\mathbf{X}, \mathbf{U F}$ & $\mathrm{x}, \mathrm{UF}$ & $x, U F$ & $\mathrm{x}, \mathrm{UI}$ \\
\hline 32 & Byers Landing & $\mathbf{x}, \mathbf{U F}$ & $\mathrm{x}, \mathrm{UF}$ & $x, U F$ & $\mathbf{x}, \mathbf{U F}$ & $x, U F$ & $\mathrm{x}, \mathrm{UF}$ & $x$, UF & $\mathbf{x}, \mathbf{U F}$ & $\mathbf{x}, \mathrm{UF}$ & $\mathrm{x}, \mathrm{UF}$ & $\mathbf{x}, \mathbf{U I}$ \\
\hline 33 & Riverview - Harris & $\mathrm{x}, \mathrm{UF}$ & $\mathbf{x}, \mathbf{U F}$ & $\mathrm{x}, \mathrm{UF}$ & $\mathbf{x}, \mathbf{U F}$ & $\mathbf{x}, \mathbf{U F}$ & $\mathrm{x}, \mathrm{UF}$ & $\mathbf{x}, \mathbf{U F}$ & $\mathrm{x}, \mathrm{UF}$ & $\mathrm{x}, \mathrm{UF}$ & $\mathrm{x}, \mathrm{UF}$ & $\mathrm{x}, \mathrm{UI}$ \\
\hline 34 & Benton City & $\mathrm{x}, \mathrm{UF}$ & $\mathbf{x}, \mathbf{U F}$ & $\mathrm{x}, \mathrm{UF}$ & $\mathrm{x}, \mathrm{UF}$ & $\mathrm{x}, \mathrm{UF}$ & $\mathbf{x}, \mathbf{U F}$ & $\mathbf{x}$, UF & $\mathbf{x}$, UF & & & \\
\hline 35 & Sunnyside & $\mathrm{x}, \mathrm{UF}$ & $x$, UF & $\mathrm{x}, \mathrm{UF}$ & $\mathbf{x}, \mathbf{U F}$ & $\mathrm{x}, \mathrm{UF}$ & $\mathrm{x}, \mathrm{UF}$ & $\mathrm{x}, \mathrm{UF}$ & $\mathbf{x}, \mathbf{U F}$ & & $\mathrm{x}, \mathrm{UF}$ & $\mathrm{x}, \mathrm{UI}$ \\
\hline 36 & McNary Dam & & & & & $\mathrm{x}, \mathrm{UF}$ & $\mathrm{x}, \mathrm{UF}$ & $\mathrm{x}, \mathrm{UF}$ & $\mathrm{x}, \mathrm{UF}$ & & & \\
\hline 37 & Walla Walla & & & & & $x$, UF & $\mathbf{x}, \mathbf{U F}$ & $\mathrm{x}, \mathrm{UF}$ & $\mathrm{x}, \mathrm{UF}$ & & & \\
\hline 38 & Washtucna & & & & & $\mathrm{x}, \mathrm{UF}$ & $\mathbf{x}, \mathbf{U F}$ & $\mathbf{x}$, UF & $\mathbf{x}, \mathbf{U F}$ & & & \\
\hline 39 & Yakima & & & & & $\mathbf{x}, \mathbf{U F}$ & $\mathrm{x}, \mathrm{UF}$ & $\mathbf{x}, \mathrm{UF}$ & $\mathbf{x}$, UF & $x, U I$ & $\mathrm{x}, \mathrm{UI}$ & $\mathrm{x}, \mathrm{UI}$ \\
\hline 40 & Othello & & & & & $\mathrm{x}, \mathrm{UF}$ & $\mathrm{x}, \mathrm{UF}$ & $\mathrm{x}, \mathrm{UF}$ & $\mathrm{x}, \mathrm{UF}$ & & & \\
\hline 41 & Connell & & & & & $\mathbf{x}, \mathrm{UF}$ & $\mathbf{x}, \mathbf{U F}$ & $\mathrm{x}, \mathrm{UF}$ & $\mathbf{x}, \mathbf{U F}$ & & & \\
\hline 42 & Moses Lake & & & & & $\mathbf{x}, \mathrm{UF}$ & $x$, UF & $\mathbf{x}, \mathrm{UF}$ & $\mathrm{x}, \mathrm{UF}$ & $\mathrm{x}, \mathrm{UI}$ & & \\
\hline
\end{tabular}

Key $\mathrm{x}=$ Gamma Spectra (Co-60, Cs-137), Sr-90, Pu-iso; UF = U fluorometric; UI = U alpha spec. 


\section{Appendix C}

Statistical Analysis Tables and Box Plots 


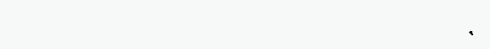


This appendix contains two sections. The first section contains ANOVA tables and post hoc analysis tables that document the analysis of differences of radionuclide concentrations in either soil or vegetation between areas. These tables are found on pages C.3 through C.12 and follow the order of the main report. The second section contains box plots for each radionuclide covered in the report (pages C.13-24).

Table C.1. ANOVA of Transformed ${ }^{60} \mathrm{Co}$ in Soils by Area

$\begin{array}{lccccc} & \text { DF } & \text { Sum of Squares } & \frac{\text { Mean Square }}{\text { F-Value }} & \frac{\text { P-Value }}{6.77} & <0.0001 \\ \text { Area } & 4 & 1.047 & 0.262 & 0.039 & \end{array}$

Table C.2. Scheffé's Comparison of Log-Transformed ${ }^{60}$ Co in Soils

$\begin{array}{lcccc} & \text { Count } & \text { Mean } & \text { Standard Deviation } & \\ \text { 100 Areas } & 35 & -1.148 & 0.233 & \\ \text { 200 Areas } & 65 & -1.337 & 0.228 & 0.039 \\ \text { 300 Area } & 18 & -1.382 & 0.311 & 0.028 \\ \text { 600 Area } & 62 & -1.320 & 0.148 & 0.073 \\ \text { Offsite } & 154 & -1.307 & 0.173 & 0.019 \\ & & & & 0.014\end{array}$

Scheffé's Post Hoc Comparisons

\begin{tabular}{|c|c|c|c|c|}
\hline \multicolumn{2}{|c|}{ Areas of Comparison } & Mean Difference & Critical Difference & $\underline{\mathrm{P}-\text { Value }}$ \\
\hline 100 Areas & 200 Areas & 0.1890 & 0.1280 & 0.0004 \\
\hline 100 Areas & 300 Area & 0.2340 & 0.1770 & 0.0025 \\
\hline 100 Areas & 600. Area & 0.1720 & 0.1290 & 0.0022 \\
\hline 100 Areas & Offsite & 0.1580 & 0.1140 & 0.0012 \\
\hline 200 Areas & 300 Area & 0.0450 & 0.1620 & 0.9460 \\
\hline 200 Areas & 600 Area & -0.0170 & 0.1080 & 0.9931 \\
\hline 200 Areas & Offsite & -0.0300 & 0.0900 & 0.8951 \\
\hline 300 Area & 600 Area & -0.0620 & 0.1630 & 0.8438 \\
\hline 300 Area & Offsite & -0.0750 & 0.1520 & 0.6672 \\
\hline 600 Area & Offsite & -0.0130 & 0.0920 & 0.9954 \\
\hline
\end{tabular}


Table C.3. ANOVA of Transformed ${ }^{90} \mathrm{Sr}$ in Soils by Area

$\begin{array}{lccccc} & \text { DF } & \text { Sum of Squares } & \frac{\text { Mean Square }}{4.483} & \frac{\text { F-Value }}{15.914} & \frac{\text { P-Value }}{<0.0001} \\ \text { Area } & 4 & 9.932 & 51.177 & 0.156 & \end{array}$

Table C.4. Scheffé's Comparison of Log-Transformed ${ }^{90} \mathrm{Sr}$ in Soils

$\begin{array}{lcccc} & \text { Count } & \text { Mean } & \text { Standard Deviation } & \text { Standard Error } \\ \text { 1.00 Areas } & 35 & -0.629 & 0.368 & 0.062 \\ \text { 200 Areas } & 65 & -0.490 & 0.416 & 0.052 \\ \text { 300 Area } & 17 & -0.564 & 0.322 & 0.078 \\ \text { 600 Area } & 62 & -0.760 & 0.415 & 0.053 \\ \text { Offsite } & 154 & -0.920 & 0.390 & 0.031\end{array}$

Scheffé's Post Hoc Comparisons

\begin{tabular}{|c|c|}
\hline \multicolumn{2}{|c|}{ Areas of Comparison } \\
\hline 100 Areas & 200 Areas \\
\hline 100 Areas & 300 Area \\
\hline 100 Areas & 600 Area \\
\hline 100 Areas & Offsite \\
\hline 200 Areas & 300 Area \\
\hline 200 Areas & 600 Area \\
\hline 200 Areas & Offsite \\
\hline 300 Area & 600 Area \\
\hline 300 Area & Offsite \\
\hline 600 Area & Offsite \\
\hline
\end{tabular}

\begin{tabular}{c} 
Mean Difference \\
\hline-0.1390 \\
-0.0650 \\
0.1310 \\
0.2910 \\
0.0730 \\
0.2690 \\
0.4300 \\
0.1960 \\
0.3570 \\
0.1610
\end{tabular}

\begin{tabular}{c} 
Critical Difference \\
\hline 0.2570 \\
0.3620 \\
0.2590 \\
0.2290 \\
0.3330 \\
0.2170 \\
0.1810 \\
0.3350 \\
0.3130 \\
0.1840
\end{tabular}

\begin{tabular}{r} 
P-Value \\
\hline 0.5929 \\
0.9889 \\
0.6547 \\
0.0043 \\
0.9769 \\
0.0060 \\
$<0.0001$ \\
0.5128 \\
0.0154 \\
0.1229
\end{tabular} 
Table C.5. ANOVA of Transformed ${ }^{90} \mathrm{Sr}$ in Vegetation by Area

\begin{tabular}{|c|c|c|c|c|c|}
\hline & $\underline{D F}$ & Sum of Squares & Mean Square & E-Value & P-Value \\
\hline Area & 4 & 14.78 & 3.695 & 19.523 & $<0.0001$ \\
\hline Residual & 276 . & 52.24 & 0.189 & & \\
\hline
\end{tabular}

Table C.6. Scheffé's Comparison of Log-Transformed ${ }^{90} \mathrm{Sr}$ in Vegetation

$\begin{array}{lcccc} & \text { Count } & \underline{\text { Mean }} & \text { Standard Deviation } & \\ \text { 100 Areas } & 28 & -1.087 & 0.487 & \text { Standard Error } \\ \text { 200 Areas } & 57 & -0.701 & 0.437 & 0.092 \\ \text { 300 Area } & 17 & -1.145 & 0.469 & 0.058 \\ \text { 600 Area } & 51 & -1.110 & 0.497 & 0.114 \\ \text { Offsite } & 128 & -1.312 & 0.389 & 0.070 \\ & & & & 0.034\end{array}$

Scheffé's Post Hoc Comparisons

\begin{tabular}{ll}
\multicolumn{2}{c}{ Areas of Comparison } \\
\hline 100 Areas & 200 Areas \\
100 Areas & 300 Area \\
100 Areas & 600 Area \\
100 Areas & Offsite \\
200 Areas & 300 Area \\
200 Areas & 600 Area \\
200 Areas & Offsite \\
300 Area & 600 Area \\
300 Area & Offsite \\
600 Area & Offsite
\end{tabular}

\begin{tabular}{c} 
Mean Difference \\
\hline-0.3860 \\
0.0570 \\
0.0220 \\
0.2250 \\
0.4440 \\
0.4090 \\
0.6110 \\
-0.0350 \\
0.1680 \\
0.2030
\end{tabular}

Critical Difference

P-Value

0.3110

0.4150

0.0059

0.3170

0.9960

0.2810

0.3730

0.9997

0.1928

0.0097

0.2600

0.2150

0.3780

0.0001

0.3480

$<0.0001$

0.9992

0.2230

0.6945

0.0981 
Table C.7. ANOVA of Transformed ${ }^{137} \mathrm{Cs}$ in Soils by Area

$\begin{array}{lccccc} & \text { DF } & \text { Sum of Squares } & \text { Mean Square } & \text { F-Value } & \text { P-Value } \\ \text { Area } & 4 & 8.038 & 2.010 & 8.579 & <0.0001 \\ \text { Residual } & 329 & 77.069 & 0.234 & \end{array}$

Table C.8. Scheffé's Comparison of Log-Transformed ${ }^{137}$ Cs in Soils

$\begin{array}{lcccc} & \text { Count } & \underline{\text { Mean }} & \text { Standard Deviation } & \\ \text { 100 Areas } & 35 & -0.154 & 0.223 & 0.038 \\ \text { 200 Areas } & 65 & -0.084 & 0.741 & 0.092 \\ \text { 300 Area } & 18 & -0.185 & 0.224 & 0.053 \\ \text { 600 Area } & 62 & -0.447 & 0.395 & 0.050 \\ \text { Offsite } & 154 & -0.438 & 0.442 & 0.036\end{array}$

Scheffé's Post Hoc Comparisons

\begin{tabular}{|c|c|c|c|c|}
\hline \multicolumn{2}{|c|}{ Areas of Comparison } & Mean Difference & Critical Difference & $\underline{\mathrm{P}-\text { Value }}$ \\
\hline 100 Areas & 200 Areas & -0.0700 & 0.3140 & 0.9758 \\
\hline 100 Areas & 300 Area & 0.0310 & 0.4350 & 0.9997 \\
\hline 100 Areas & 600 Area & 0.2930 & 0.3170 & 0.0865 \\
\hline 100 Areas & Offsite & 0.2840 & 0.2810 & 0.0458 \\
\hline 200 Areas & 300 Area & 0.1010 & 0.3990 & 0.9613 \\
\hline 200 Areas & 600 Area & 0.3630 & 0.2660 & 0.0016 \\
\hline 200 Areas & Offsite & 0.3540 & 0.2220 & $<0.0001$ \\
\hline 300 Area & 600 Area & 0.2620 & 0.4010 & 0.3948 \\
\hline 300 Area & Offsite & 0.2530 & 0.3730 & 0.3568 \\
\hline 600 Area & Offsite & -0.0095 & 0.2260 & $>0.9999$ \\
\hline
\end{tabular}


Table C.9. ANOVA of Transformed ${ }^{137} \mathrm{Cs}$ in Vegetation by Area

$\begin{array}{lccccc} & \mathrm{DF} & \frac{\text { Sum of Squares }}{2.744} & \frac{\text { Mean Square }}{0.686} & \frac{\text { F-Value }}{5.949} & \frac{\text { P-Value }}{0.0001} \\ \text { Area } & 291 & 33.562 & 0.115 & & \end{array}$

Table C.10. Scheffé's Comparison of Log-Transformed ${ }^{137} \mathrm{Cs}$ in Vegetation

\begin{tabular}{|c|c|c|c|c|}
\hline & Count & Mean & Standard Deviation & Standard Error \\
\hline 100 Areas & & -1.341 & 0.217 & 0.040 \\
\hline 200 Areas & 58 & -1.077 & 0.272 & 0.036 \\
\hline $300 \mathrm{Ar}$ & 18 & -1.301 & 0.234 & 0.055 \\
\hline 600 & 52 & -1.367 & 0.300 & 0.042 \\
\hline Offsite & 139 & -1.258 & 0.404 & 0.034 \\
\hline
\end{tabular}

Scheffé's Post Hoc Comparisons

\begin{tabular}{|c|c|c|c|c|}
\hline \multicolumn{2}{|c|}{ Areas of Comparison } & Mean Difference & Critical Difference & $\underline{\mathrm{P} \text {-Value }}$ \\
\hline 100 Areas & 200 Areas & -0.2640 & 0.2390 & $\overline{0.0216}$ \\
\hline 100 Areas & 300 Area & -0.0390 & 0.3160 & 0.9973 \\
\hline 100 Areas & 600 Area & 0.0260 & 0.2440 & 0.9985 \\
\hline 100 Areas & Offsite & -0.0830 & 0.2150 & 0.8397 \\
\hline 200 Areas & 300 Area & 0.2250 & 0.2840 & 0.2016 \\
\hline 200 Areas & 600 Area & 0.2900 & 0.2010 & 0.0007 \\
\hline 200 Areas & Offsite & 0.1810 & 0.1650 & 0.0218 \\
\hline 300 Area & 600 Area & 0.0650 & 0.2880 & 0.9736 \\
\hline 300 Area & Offsite & -0.0430 & 0.2640 & 0.9922 \\
\hline 600 Area & Offsite & -0.1090 & 0.1710 & 0.4231 \\
\hline
\end{tabular}


Table C.11. ANOVA of Transformed U (Fluorometric Analysis) in Soil by Area

Area

$\frac{\text { DF }}{4} \quad \frac{\text { Sum of Squares }}{2.2243}$

Mean Square

F-Value $\quad$ P-Value

Residual

$\begin{array}{ll}165 & 7.3749\end{array}$

0.5561

0.0447

$\frac{\text { P-Value }}{12.4411} \quad<0.0001$

Table C.12. Scheffé's Comparison of Log-Transformed U (Fluorometric Analysis) in Soil

\begin{tabular}{lcccc} 
& Count & \multicolumn{1}{c}{ Mean } & Standard Deviation & \\
100 Areas & 15 & -0.451 & 0.129 & Standard Error \\
200 Areas & 35 & -0.464 & 0.155 & 0.033 \\
300 Area & 10 & 0.010 & 0.404 & 0.026 \\
600 Area & 33 & -0.516 & 0.149 & 0.128 \\
Offsite & 77 & -0.436 & 0.233 & 0.026 \\
\end{tabular}

Scheffé's Post Hoc Comparisons

\begin{tabular}{ll}
\multicolumn{2}{c}{ Areas of Comparison } \\
\hline 100 Areas & 200 Areas \\
100 Areas & 300 Area \\
100 Areas & 600 Area \\
100 Areas & Offsite \\
200 Areas & 300 Area \\
200 Areas & 600 Area \\
200 Areas & Offsite \\
300 Area & 600 Area \\
300 Area & Offsite \\
600 Area & Offsite
\end{tabular}

\begin{tabular}{c} 
Mean Difference \\
\hline 0.0128 \\
-0.4606 \\
0.0648 \\
-0.0146 \\
-0.4734 \\
0.0520 \\
-0.0274 \\
0.5254 \\
0.4460 \\
-0.0794
\end{tabular}

Critical Difference

P-Value

0.2033

0.2689

0.2051

0.1859

$<0.0001$

0.9140

0.2362

0.1598

0.9996

$<0.0001$

0.1343

0.9051

0.2378

0.9819

0.2214

$<0.0001$

0.1370

$<0.0001$

0.5173 
Table C.13. ANOVA of Transformed ${ }^{238} \mathrm{U}$ (LEPS) in Soil by Area

\begin{tabular}{|c|c|c|c|c|c|}
\hline & DF & Sum of Squares & Mean Square & F-Value & $\underline{\text { P-Value }}$ \\
\hline Area & $\frac{11}{4}$ & 0.2154 & 0.0539 & 1.4668 & 0.2149 \\
\hline Residual & 157 & 5.7636 & 0.0367 & & \\
\hline
\end{tabular}

Table C.14. ANOVA of Transformed ${ }^{238} \mathrm{U}$ (Alpha Spectroscopy) in Soil by Area

Area

Residual $\frac{\text { DF }}{4} \quad \frac{\text { Sum of Squares }}{0.0375}$

$39 \quad 0.2584$
$\underline{\text { Mean Square }}$
0.0094
0.0066

$\frac{\text { F-Value }}{1.4138} \quad \frac{\text { P-Value }}{0.2475}$

Table C.15. ANOVA of Transformed U (Fluorometric Analysis) in Vegetation by Area

\begin{tabular}{|c|c|c|c|c|c|}
\hline & DF & Sum of Squares & Mean Square & F-Value & $\underline{\mathrm{P}-\text { Value }}$ \\
\hline Area & -4 & 1.45498 & 0.36374 & 3.65133 & 0.0065 \\
\hline Residual & 260 & 25.90113 & 0.09962 & & \\
\hline
\end{tabular}

Table C.16. Scheffé's Comparison of Log-Transformed U (Fluorometric Analysis) in Vegetation

\begin{tabular}{|c|c|c|c|c|}
\hline & $\underline{\text { Count }}$ & Mean & Standard Deviation & Standard Error \\
\hline 100 Areas & $\overline{24}$ & $-\overline{1.7679}$ & 0.1527 & 0.0312 \\
\hline 200 Areas & 56 & -1.6702 & 0.1610 & 0.0215 \\
\hline 300 Area & 17 & -1.5182 & 0.1776 & 0.0431 \\
\hline 600 Area & 48 & -1.7196 & 0.1272 & 0.0184 \\
\hline Offsite & 120 & -1.5782 & 0.4365 & 0.0399 \\
\hline
\end{tabular}

Scheffé's Post Hoc Comparisons

\begin{tabular}{|c|c|c|c|c|}
\hline \multicolumn{2}{|c|}{ Areas of Comparison } & Mean Difference & Critical Difference & P-Value \\
\hline 100 Areas & 200 Areas & -0.1390 & 0.2570 & 0.5929 \\
\hline 100 Areas & 200 Areas & -0.0977 & 0.2389 & 0.8066 \\
\hline 100 Areas & 300 Area & -0.2497 & 0.3104 & 0.1863 \\
\hline 100 Areas & 600 Area & -0.0483 & 0.2448 & 0.9844 \\
\hline 100 Areas & Offsite & -0.1897 & 0.2190 & 0.1279 \\
\hline 200 Areas & 300 Area & -0.1519 & 0.2712 & 0.5551 \\
\hline 200 Areas & 600 Area & 0.0494 & 0.1926 & 0.9591 \\
\hline 200 Areas & Offsite & -0.0920 & 0.1585 & 0.5193 \\
\hline 300 Area & 600 Area & 0.2014 & 0.2764 & 0.2793 \\
\hline 300 Area & Offsite & 0.0600 & 0.2538 & 0.9696 \\
\hline 600 Area & Offsite & -0.1414 & 0.1672 & 0.1459 \\
\hline
\end{tabular}


Table C.17. ANOVA of Transformed ${ }^{238} \mathrm{Pu}$ in Soils by Area

\begin{tabular}{|c|c|c|c|c|c|}
\hline & $\underline{D F}$ & Sum of Squares & Mean Square & F-Value & $\underline{P-V a l u e}$ \\
\hline Region & 4 & 3.09848 & 0.77462 & 5.35365 & 0.0003 \\
\hline Residual & 328 & 47.45839 & 0.14469 & & \\
\hline
\end{tabular}

Table C.18. Scheffé's Comparison of Log-Transformed ${ }^{238} \mathrm{Pu}$ in Soils

\begin{tabular}{|c|c|c|c|c|}
\hline & Count & Mean & Standard Deviation & Standard Error \\
\hline 100 Areas & 154 & $-3 \overline{32734}$ & 0.34477 & 0.02778 \\
\hline 200 Areas & 35 & -3.30103 & 0.34628 & 0.05853 \\
\hline 300 Area & 65 & -3.11059 & 0.49047 & 0.06084 \\
\hline 600 Area & 17 & -3.29958 & 0.24789 & 0.06012 \\
\hline Offsite & 62 & -3.40315 & 0.38015 & 0.04828 \\
\hline
\end{tabular}

Scheffé's Post Hoc Comparisons

\begin{tabular}{|c|c|c|c|c|}
\hline \multicolumn{2}{|c|}{ Areas of Comparison } & Mean Difference & Critical Difference & $\underline{\text { P-Value }}$ \\
\hline 100 Areas & 200 Areas & 0.1904 & 0.2471 & 0.2251 \\
\hline 100 Areas & 300 Area & 0.0015 & 0.3484 & $>0.9999$ \\
\hline 100 Areas & 600 Area & -0.1021 & 0.2491 & 0.8064 \\
\hline 100 Areas & Offsite & 0.0263 & 0.2207 & 0.9978 \\
\hline 200 Areas & 300 Area & -0.1890 & 0.3210 & 0.5058 \\
\hline 200 Areas & 600 Area & -0.2926 & 0.2092 & 0.0011 \\
\hline 200 Areas & Offsite & 0.2168 & 0.1743 & 0.0057 \\
\hline 300 Area & 600 Area & -0.1036 & 0.3226 & 0.9112 \\
\hline 300 Area & Offsite & 0.0278 & 0.3012 & 0.9992 \\
\hline 600 Area & Offsite & -0.0758 & 0.1772 & 0.7804 \\
\hline
\end{tabular}




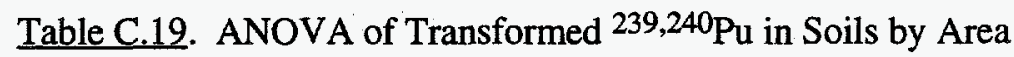

$\begin{array}{lccccc} & \text { DF } & \text { Sum of Squares } & \frac{\text { Mean Square }}{2.40883} & \frac{\text { F-Value }}{11.1176} & \frac{\text { P-Value }}{<0.0001} \\ \text { Area } & 4 & 9.63533 & 71.06742 & 0.21667 & \end{array}$

Table C.20. Scheffé's Comparison of Log-Transformed ${ }^{239,240} \mathrm{Pu}$ in Soils .

\begin{tabular}{|c|c|c|c|c|}
\hline & Count & Mean & Standard Deviation & Standard Error \\
\hline 100 Areas & 35 & -1.9057 & 0.30552 & 0.05164 \\
\hline 200 Areas & 65 & -1.7229 & 0.71644 & 0.08886 \\
\hline 300 Area. & 17 & -1.8662 & 0.22373 & 0.05426 \\
\hline 600 Area & 62 & -2.1054 & 0.37351 & 0.04744 \\
\hline Offsite & 154 & -2.1496 & 0.41010 & 0.03305 \\
\hline
\end{tabular}

Scheffé's Post Hoc Comparisons

\begin{tabular}{ll}
\multicolumn{2}{c}{ Areas of Comparison } \\
\hline 100 Areas & 200 Areas \\
100 Areas & 300 Area \\
100 Areas & 600 Area \\
100 Areas & Offsite \\
200 Areas & 300 Area \\
200 Areas & 600 Area \\
200 Areas & Offsite \\
300 Area & 600 Area \\
300 Area & Offsite \\
600 Area & Offsite
\end{tabular}

\begin{tabular}{c} 
Mean Difference \\
\hline-0.1829 \\
-0.0395 \\
0.1997 \\
0.2439 \\
0.1433 \\
0.3826 \\
0.4267 \\
0.2392 \\
0.2834 \\
0.0442
\end{tabular}

\begin{tabular}{c} 
Critical Difference \\
\hline 0.3023 \\
0.4263 \\
0.3049 \\
0.2700 \\
0.3928 \\
0.2560 \\
0.2133 \\
0.3948 \\
0.3685 \\
0.2169
\end{tabular}

P-Value

0.4774

0.9992

0.3921

0.1008

0.8649

0.0003

$<0.0001$

0.4755

0.2274

0.9825 
Table C.21. ANOVA of Transformed ${ }^{239,240} \mathrm{Pu}$ in Vegetation by Area

$\begin{array}{lccccc} & \text { DF } & \text { Sum of Squares } & \frac{\text { Mean Square }}{3.20388} & \frac{\text { F-Value }}{24.4029} & \frac{\text { P-Value }}{<0.0001} \\ \text { Location } & 4 & 12.81551 & 0.13129 & & \end{array}$

Table C.22. Scheffé's Comparison of Log-Transformed ${ }^{239,240 . P u ~ i n ~ V e g e t a t i o n ~}$

\begin{tabular}{|c|c|c|c|c|}
\hline & Count & Mean & Standard Deviation & $\underline{\text { Standard Error }}$ \\
\hline 100 Areas & 28 & -3.3465 & 0.43239 & 0.08171 \\
\hline 200 Areas & 57 & -2.93437 & 0.45222 & 0.0599 \\
\hline 300 Area & 17 & -3.34047 & 0.33356 & 0.0809 \\
\hline 600 Area & 51 & -3.33863 & 0.23437 & 0.03282 \\
\hline Offsite & 128 & -3.50417 & 0.34606 & 0.03059 \\
\hline
\end{tabular}

Scheffé's Post Hoc Comparisons

\begin{tabular}{ll}
\multicolumn{2}{c}{ Areas of Comparison } \\
\hline 100 Areas & 200 Areas \\
100 Areas & 300 Area \\
100 Areas & 600 Area \\
100 Areas & Offsite \\
200 Areas & 300 Area \\
200 Areas & 600 Area \\
200 Areas & Offsite \\
300 Area & 600 Area \\
300 Area & Offsite \\
600 Area & Offsite
\end{tabular}

\begin{tabular}{c} 
Mean Difference \\
\hline-0.4121 \\
-0.0060 \\
-0.0079 \\
0.1577 \\
0.4061 \\
0.4043 \\
0.5698 \\
-0.0018 \\
0.1637 \\
0.1655
\end{tabular}

\begin{tabular}{c} 
Critical Difference \\
\hline 0.2593 \\
0.3455 \\
0.2643 \\
0.2344 \\
0.3105 \\
0.2166 \\
0.1789 \\
0.3147 \\
0.2901 \\
0.1861
\end{tabular}

P-Value
0.0001
$>0.9999$
$>0.9999$
0.3630
0.0030
$<0.0001$
$<0.0001$
$>0.9999$
0.5483
0.1101




\section{Box Plots}

A box plot shows the median concentrations, the 25 th percentile (bottom of box), and 75 th percentile (top of box) concentrations. Box figures with additional bars show the 10th and 90th percentiles and symbols above and below those bars show individual results outside of the 10th and 90th percentile concentrations when $N \geq 4$. Where a limited number of samples were collected, the box plots are of marginal value for depicting the distribution of the data, however it is assumed that the data follow a lognormal distribution and the median concentration provides a better estimate of central tendency than the mean. Single results for a sample area are depicted as a horizontal line. Some box plots were prepared on a log-scale because of the wide range of sample concentrations (Figure C.1). Negative concentrations cannot be presented on log-scale graphs, but are indicated when the box or 10th percentile line intersects the baseline of the figure. Box plots can be very complex when depicting several years of data covering as many as 5 areas, however; they provide a great deal of information and may require rigorous inspection. Box plots for each area are presented in the order that they have been identified with in the legend of each figure.

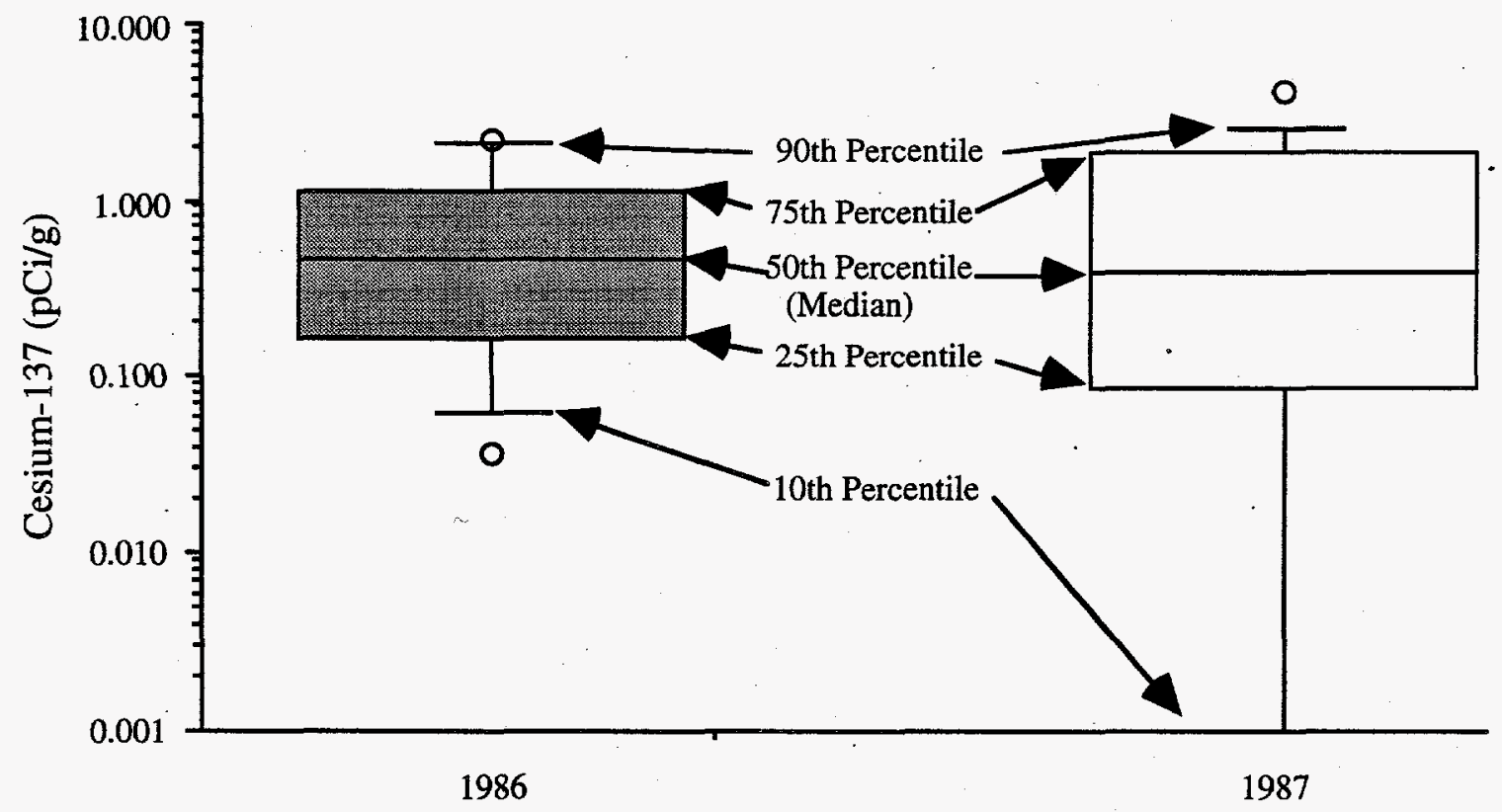

Figure C.1. Example Box Plot of Radionuclide Concentrations on a Log Scale. Symbols above or below the $90^{\text {th }}$ or $10^{\text {th }}$ percentile level represent an individual datum. 


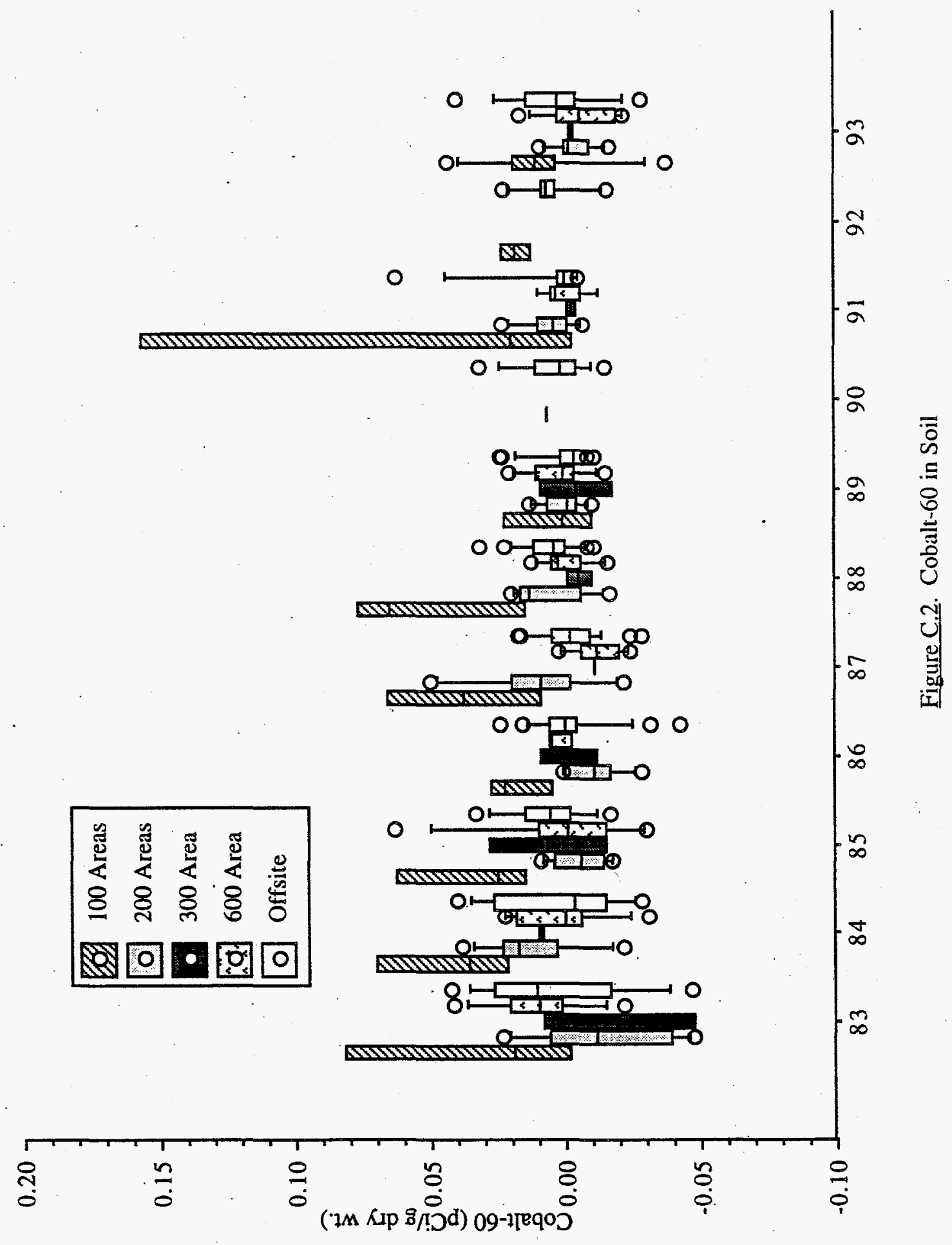




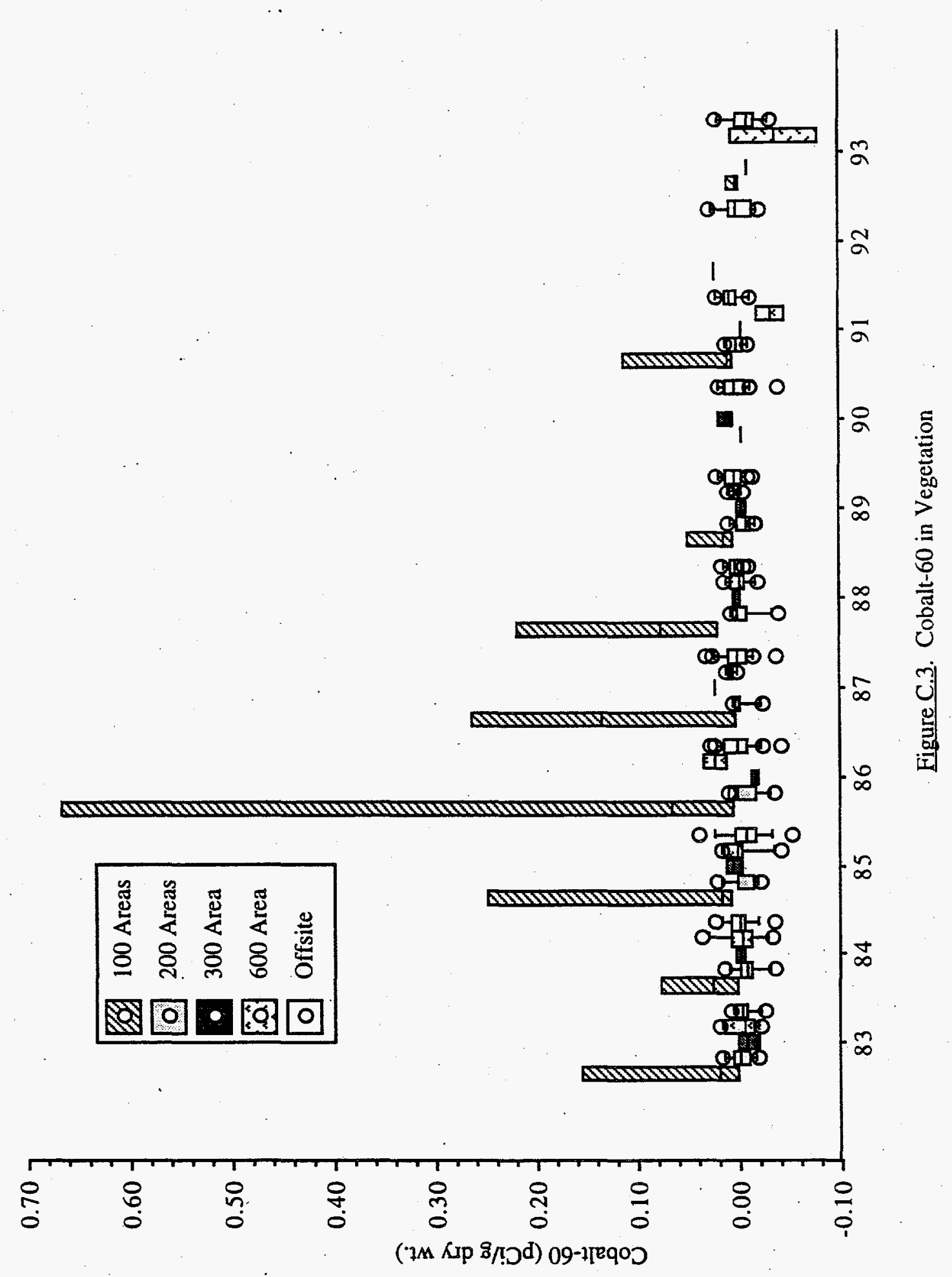

C. 15 


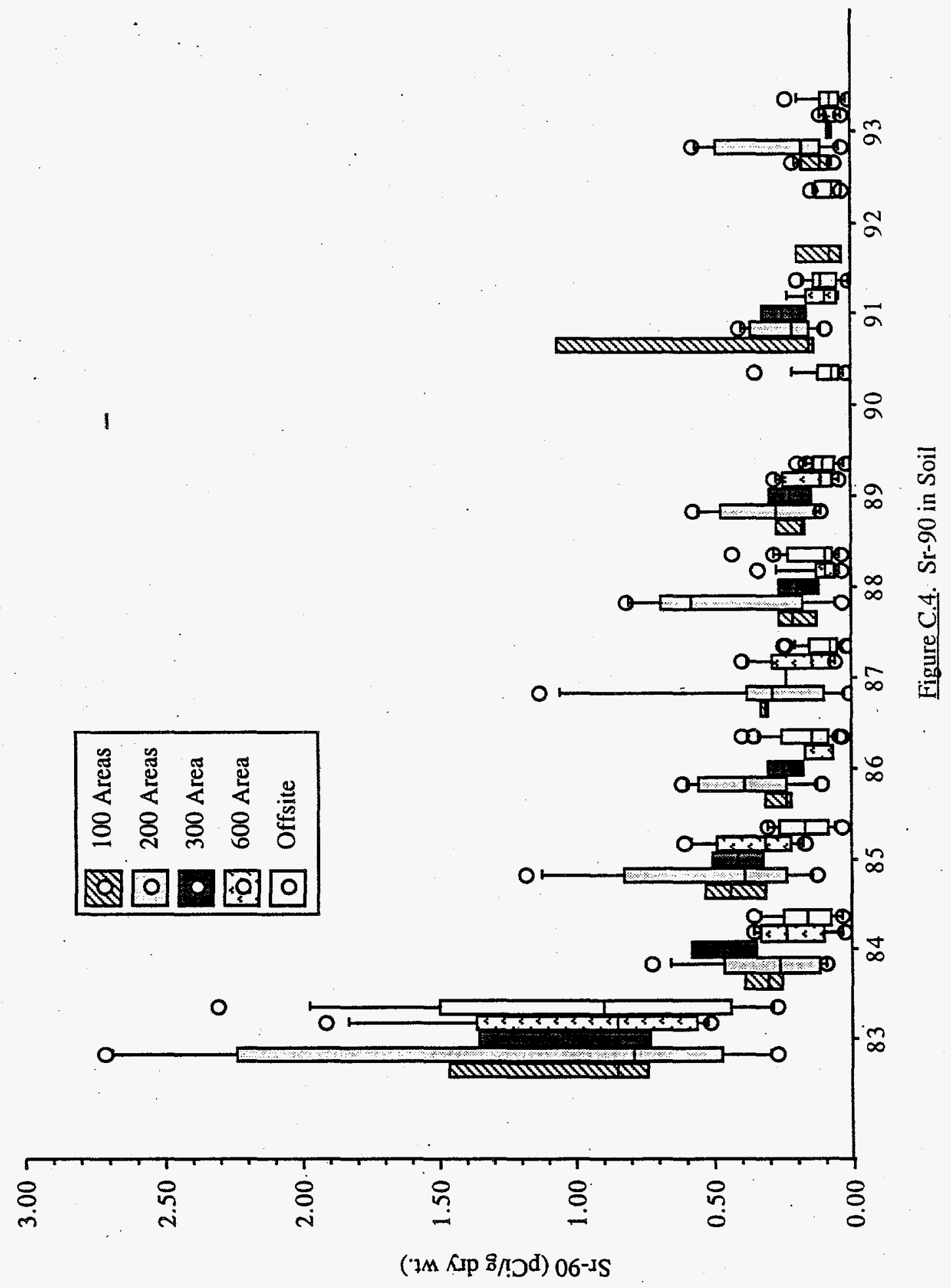

C. 16 


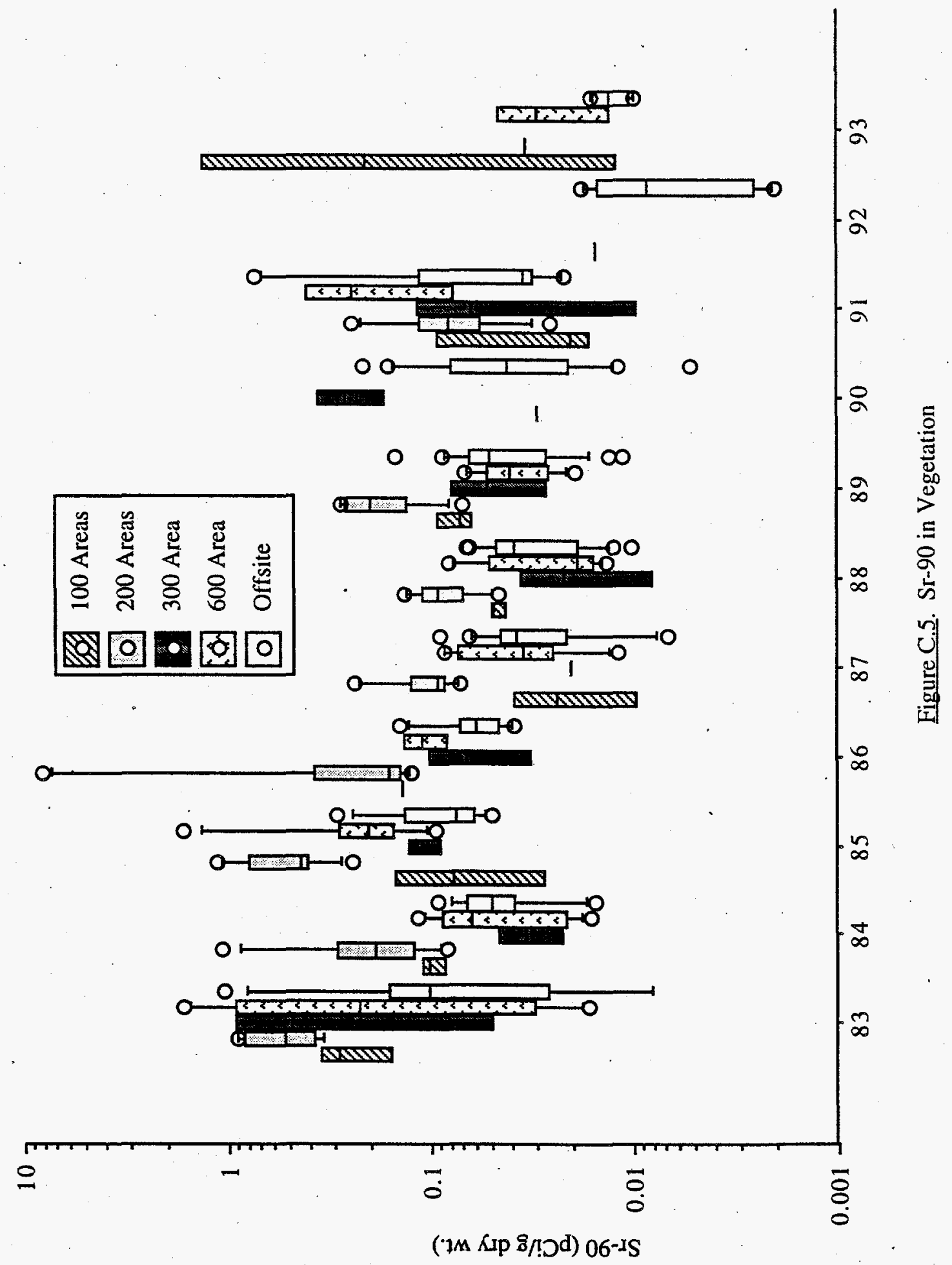

C. 17 


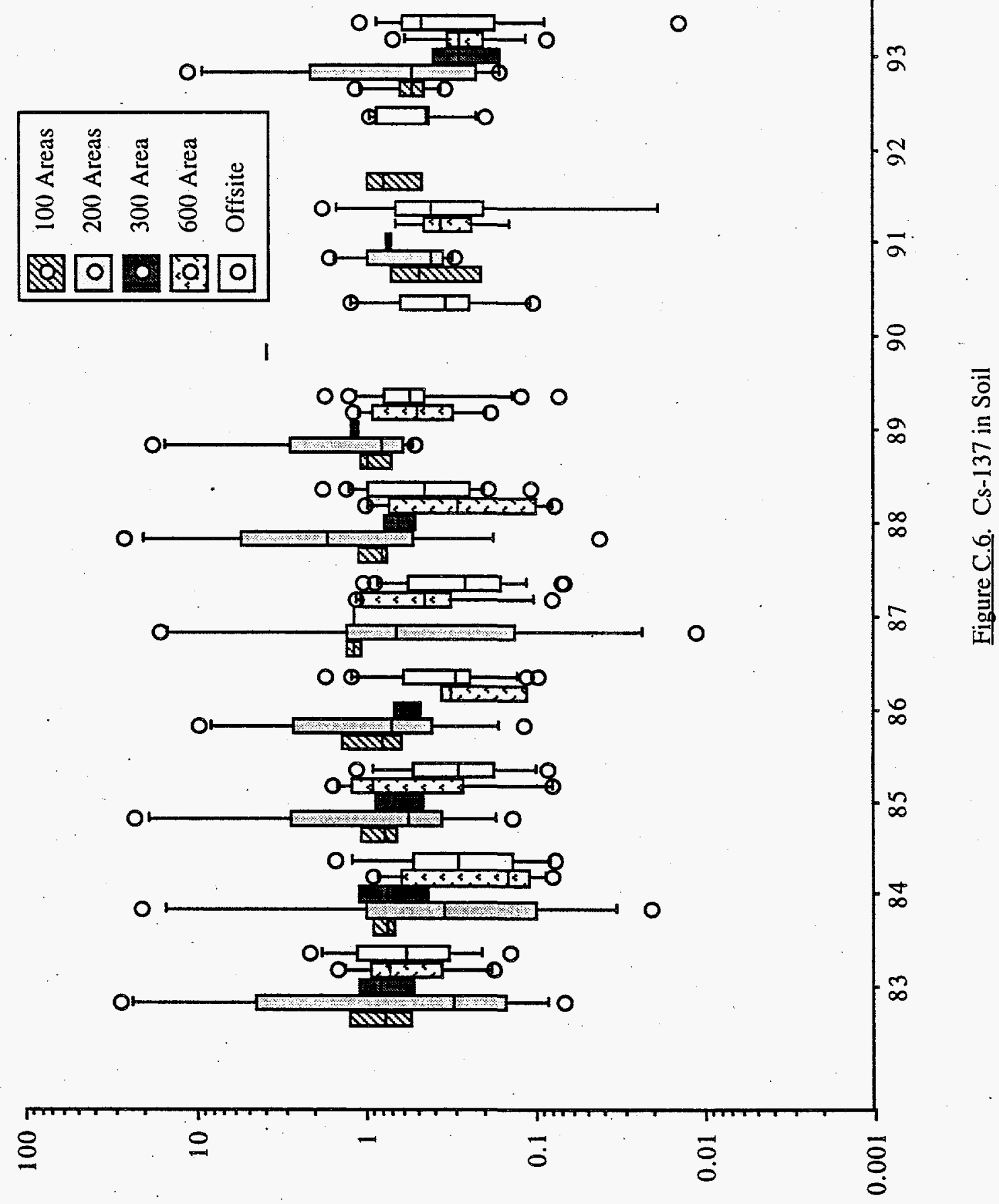

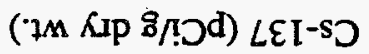




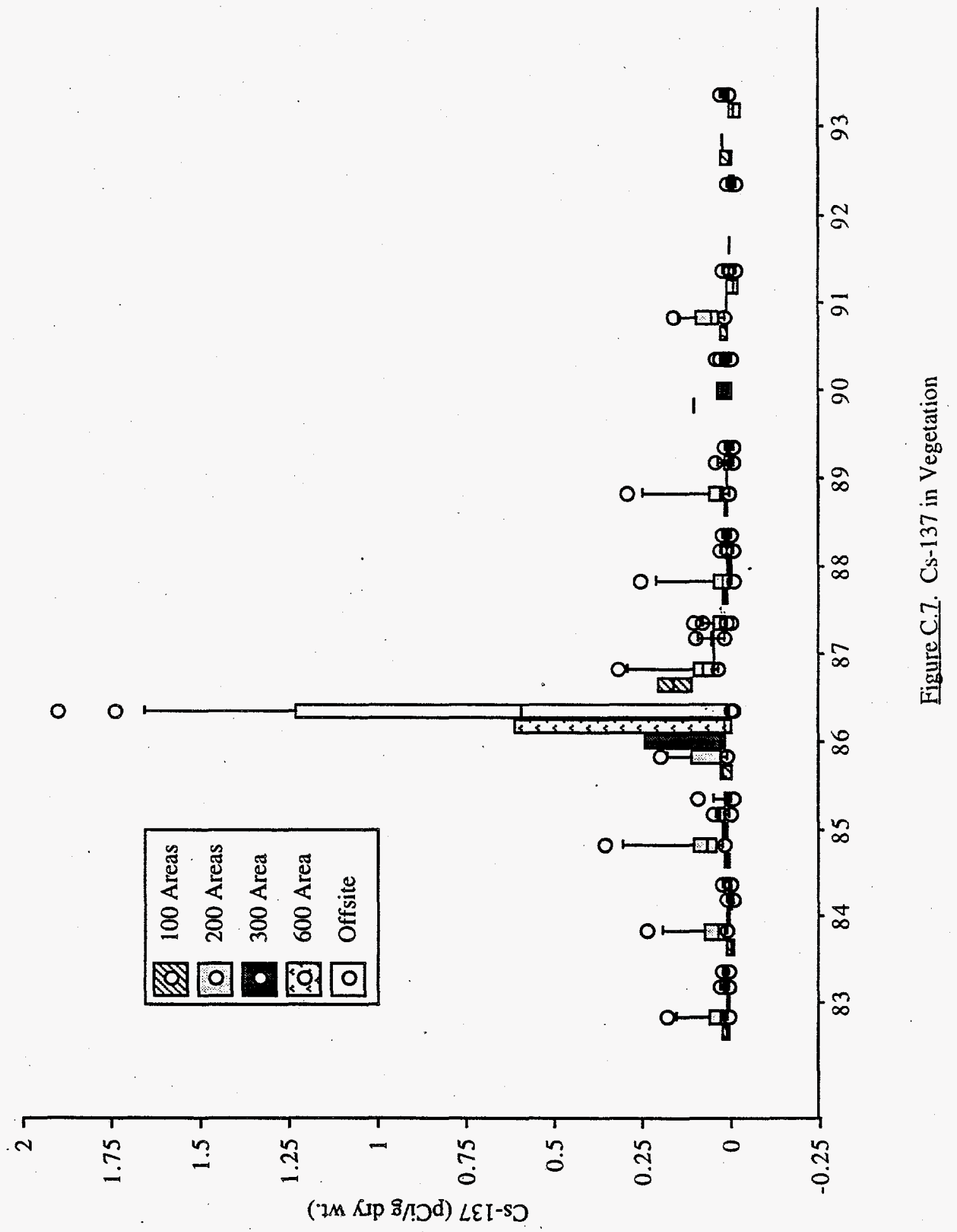

C. 19 


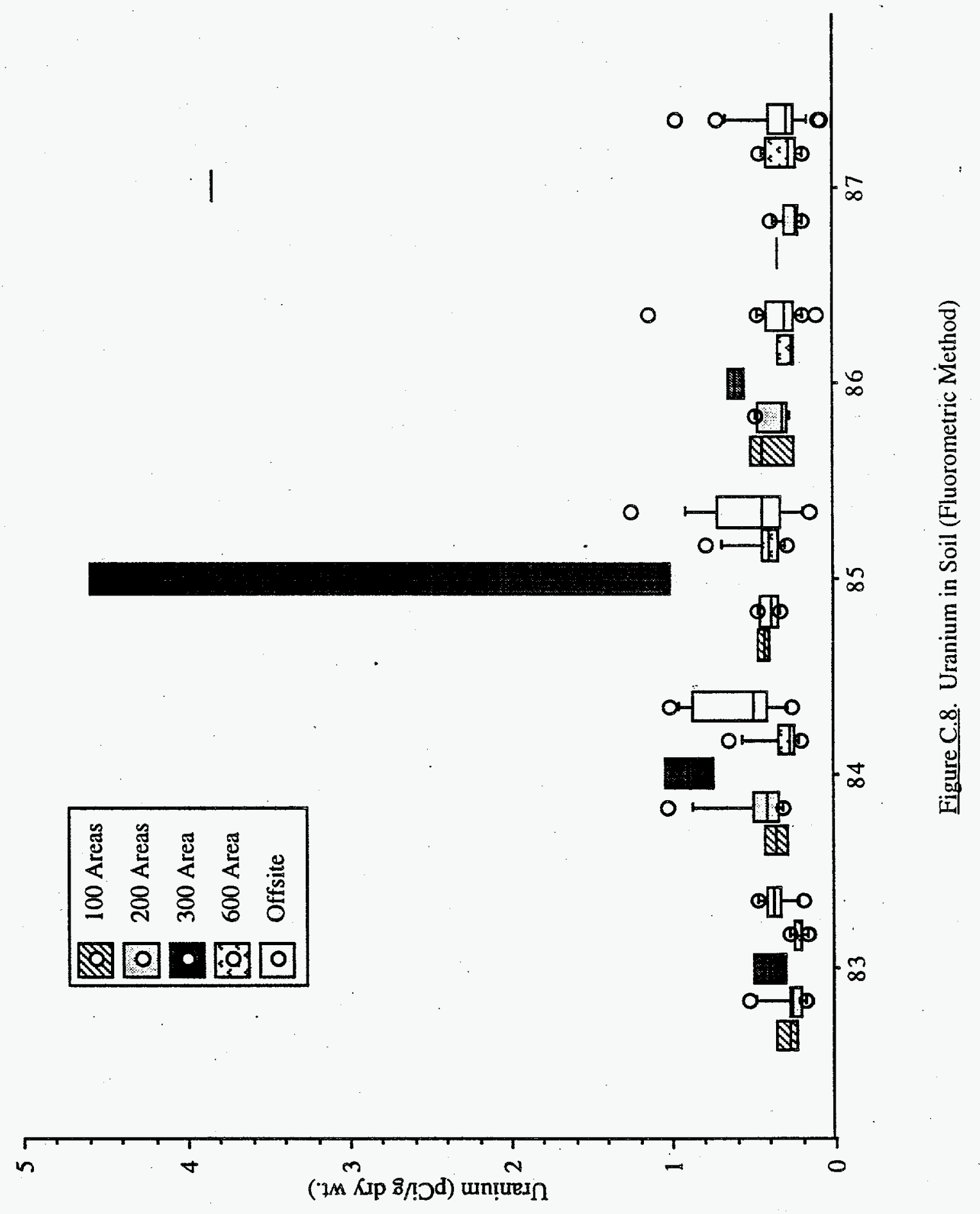



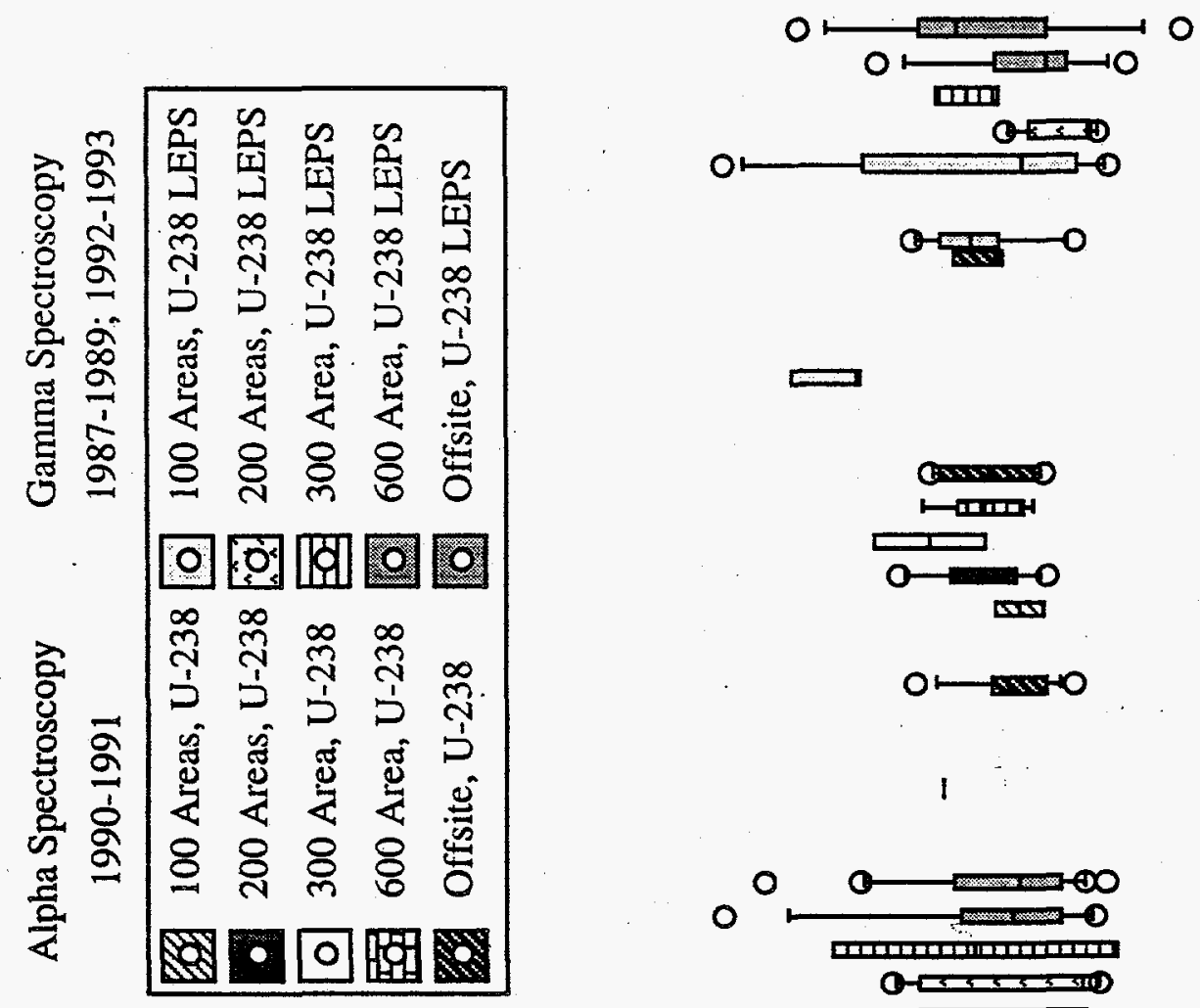

$a$
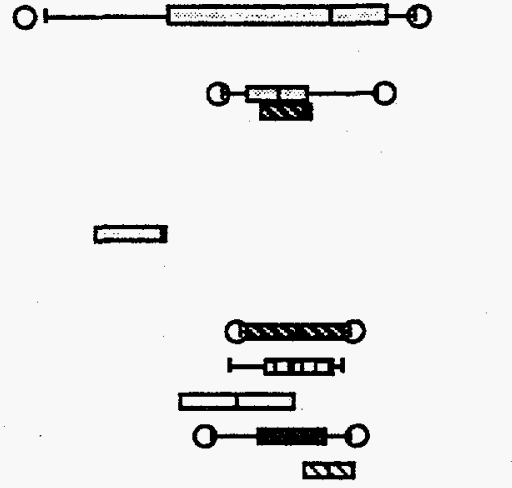

ส

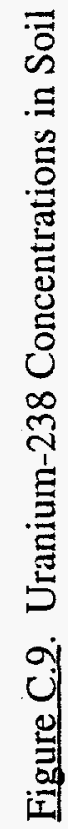

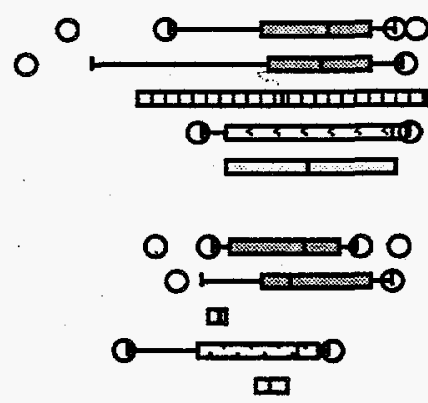

$\begin{array}{rr}\infty & 0 \\ & 0 \\ & 0 \\ & 0 \\ & 0\end{array}$

$\infty$
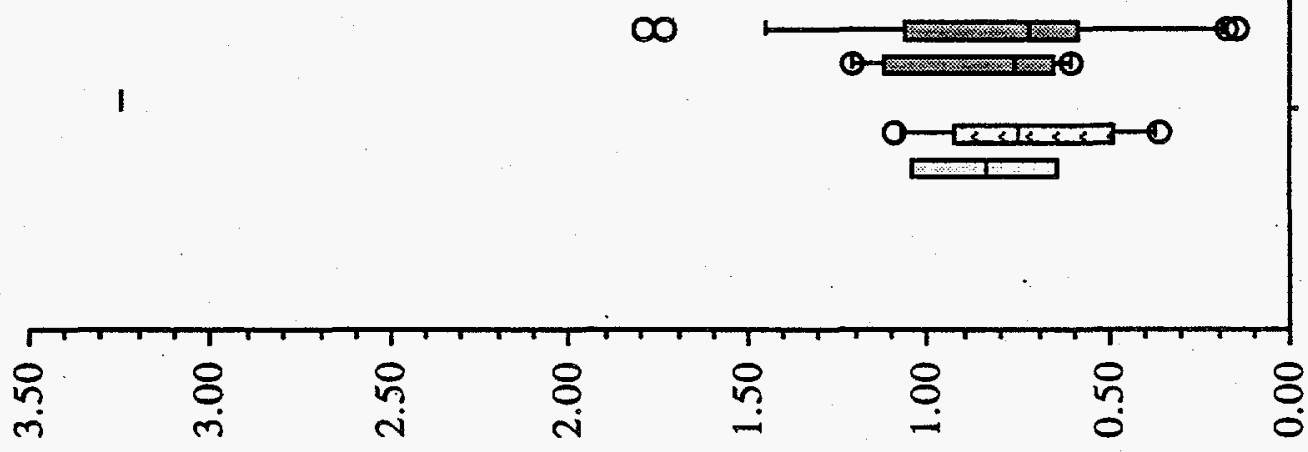

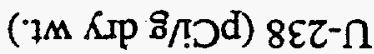




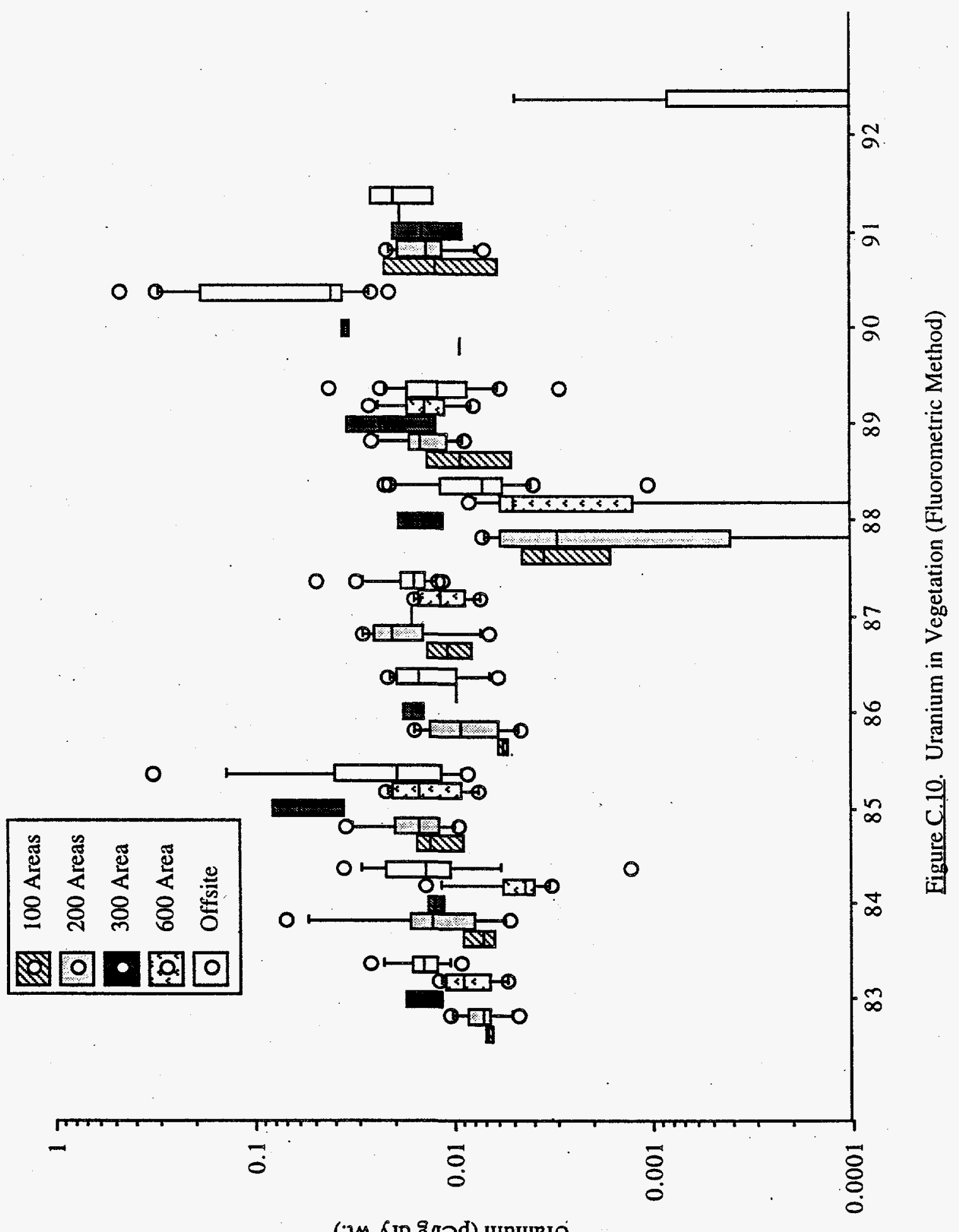

('M KIp 8/!?d) unnueI 


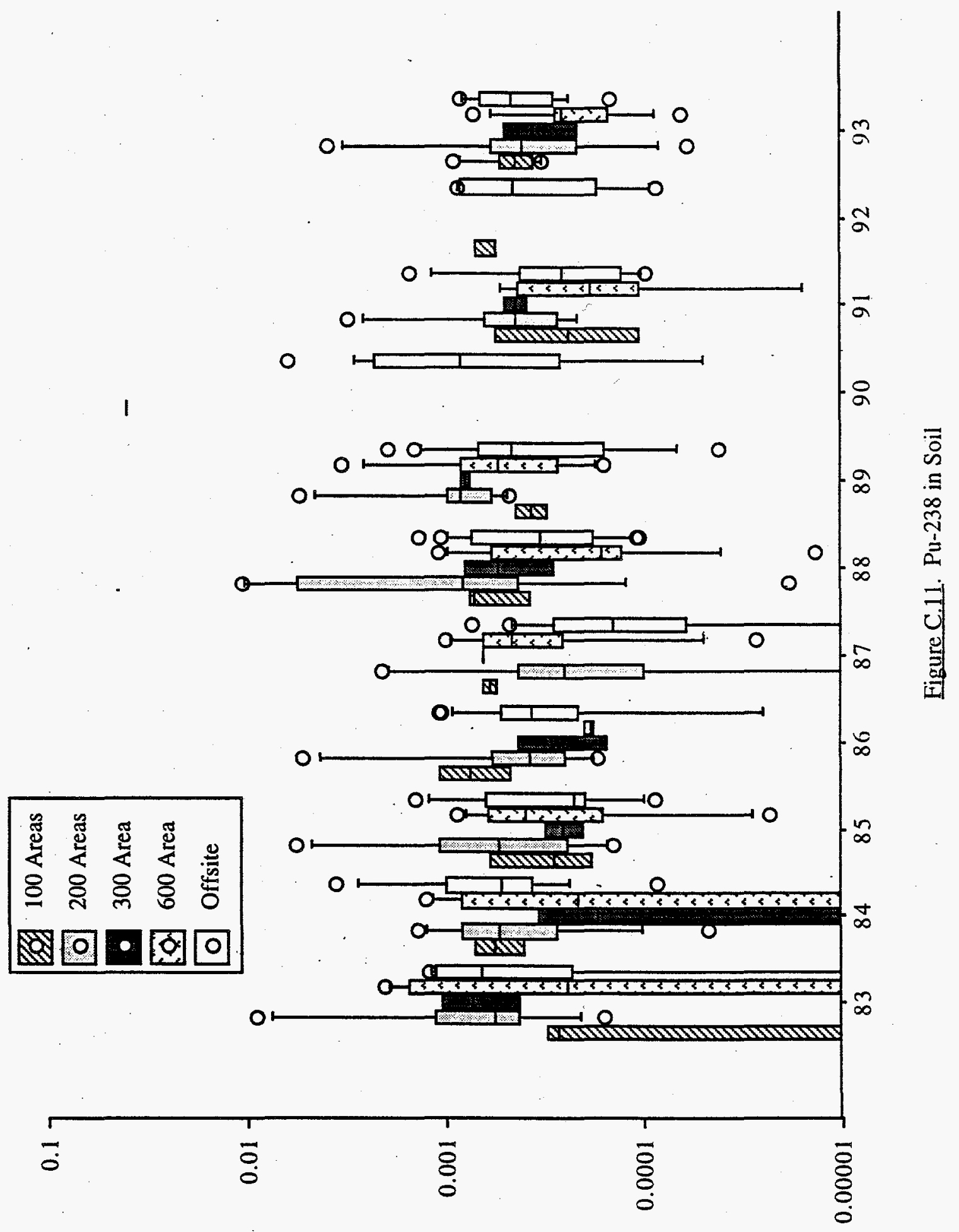

(วм KIp sి 


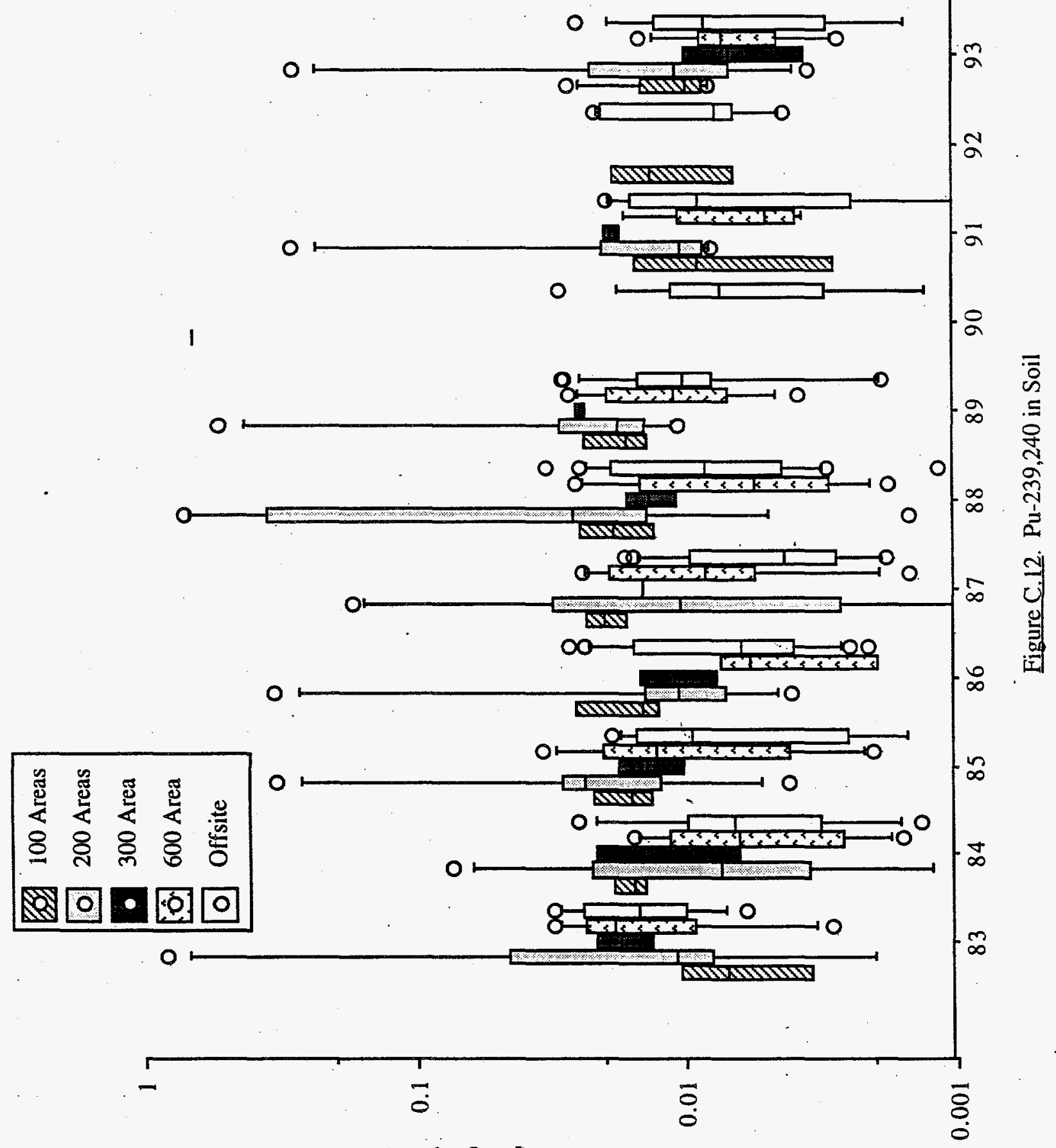

(7M KIp 8/กつd) $0 t Z^{2} 6 \varepsilon Z-n d$ 
PNL-10728

UC-602

\section{DISTRIBUTION}

No. of

Copies

OFFSITE

2 Office of Scientific and Technical Information

2 Golder Associates 4104 148th Avenue N.E Redmond, WA 98052

Attention: L. Swenson Attention: W. Wright

J. Yokel

Washington Department of Ecology

Mail Stop PV-11

Olympia, WA $98504-8711$

2 Environmental Restoration/ Waste Management Yakama Indian Nation P.O. Box 151

Toppenish, WA 98948

Attention: R. Jim

Attention: M. Bauer

4 Confederated Tribes of the

Umatilla Indian Reservation

P.O. Box 638

Pendleton, OR 97801

Attention: J. Ebaugh

Attention: J. R. Wilkinson

Attention: A. Childs

Attention: R. George

2 Nez Perce Tribe

P.O. Box 365

Lapwai, ID 83540-0365

Attention: R. Cruz

Attention: D. Powaukee
No. of

Copies

3 Washington State Department of Health

Division of Radiation Protection

Airdustrial Center

Building 5, M.S. C-13

Olympia, WA 98503

Attention: J. Erickson

Attention: L. Albin

Attention: D. Thatcher

ONSITE

11 DOE Richland Operations Office

R. F. Brich

H4-83

K. V. Clarke

A7-75

J. B. Hall (5)

A5-55

R. D. Hildebrand

A5-55

P. S. Kube

A5-15

D. C. Ward

A5-55

B. A. Ward

$\mathrm{H} 4-83$

2 U.S. Environmental Protection

Agency

L. E. Gadbois

B5-01

P. S. Innis

B5-01

8 Westinghouse Hanford Company

L. P. Diediker

S3-95

J. J. Dorian

$\mathrm{H} 6-20$

E. M. Greager

H6-20

A. R. Johnson

H6-20

C. J. Perkins

$\mathrm{X} 0-21$

J. W. Schmidt

H6-20

Public Reading Room (2)

5 Bechtel Hanford Inc.

G. E. Fitzgibbon H6-07

K. G. Gano H6-02

K. M. Leonard H6-02

S. W. Petersen H4-90

S. G. Weiss H4-92 
PNL-10728

UC-602

No. of

No. of

Copies

Copies

49 Pacific Northwest Laboratory

Routing

E. J. Antonio K6-75

M. L. Blanton K6-75

C. A. Brandt K6-84

R. W. Bryce (3) K9-34

L. L. Cadwell K6-84

A. T. Cooper K6-75

D. D. Dauble K6-85

R. L. Dirkes K6-75

S. L. Friant $\quad$ K6-77

J. A. Hall R3-12

R. W. Hanf, Jr. K6-75

P. R. Nickens K6-75

B. E. Opitz K6-79

G. W. Patton K6-75

T. M. Poston (20) K6-75

R. H. Rickard G3-06

K. A. Saldi K6-75

M. R. Sackschewsky K6-84

B. L. Tiller K6-84

R. M. Ecker SEQUIM

S. A. Rawson K9-34

R. L. Skaggs K6-91

P. C. Hays (last) K9-41

Publishing Coordination

SESP Historical Files/

R. L. Dirkes (2)

K6-75

Technical Report Files (5)

Distr. 2 